\title{
Niobium and Tantalum
}

Chapter M of

Critical Mineral Resources of the United States-Economic and Environmental Geology and Prospects for Future Supply

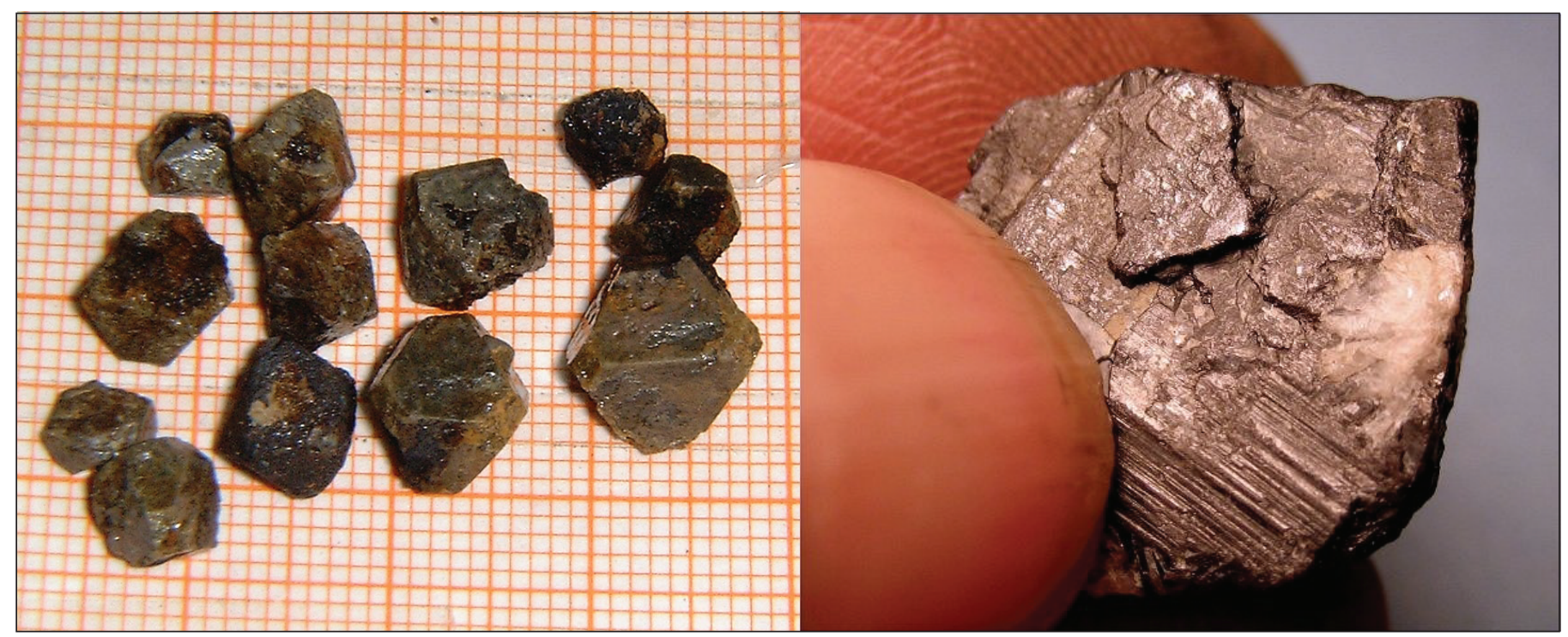

Professional Paper 1802-M 


\section{Periodic Table of Elements}

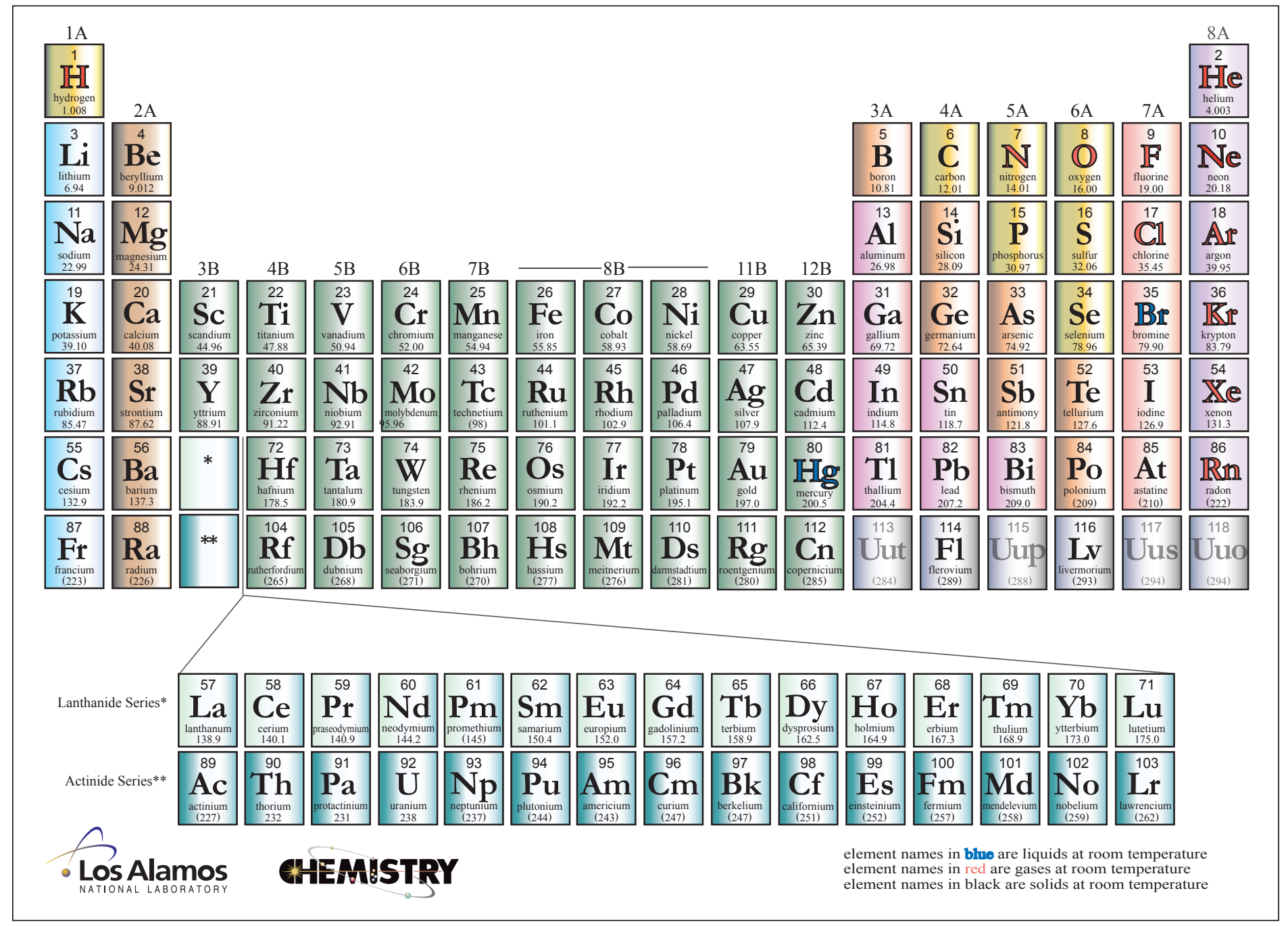

Modified from Los Alamos National Laboratory Chemistry Division; available at http://periodic.lanl.gov/images/periodictable.pdf.

Cover. Left, centimeter-size pyrochlore crystals from Uganda. Photograph by Gunnar Ries/CC-BY-SA-3.00. Right, a tantalite crystal. Photograph by Roger Weller, Cochise College. 


\section{Niobium and Tantalum}

By Klaus J. Schulz, Nadine M. Piatak, and John F. Papp

Chapter M of

Critical Mineral Resources of the United States-Economic and Environmental Geology and Prospects for Future Supply

Edited by Klaus J. Schulz, John H. DeYoung, Jr., Robert R. Seal II, and Dwight C. Bradley

Professional Paper 1802-M 


\title{
U.S. Department of the Interior RYAN K. ZINKE, Secretary
}

\section{U.S. Geological Survey William H. Werkheiser, Acting Director}

\author{
U.S. Geological Survey, Reston, Virginia: 2017
}

For more information on the USGS — the Federal source for science about the Earth, its natural and living resources, natural hazards, and the environment-visit https://www.usgs.gov or call 1-888-ASK-USGS.

For an overview of USGS information products, including maps, imagery, and publications, visit https://store.usgs.gov/.

Any use of trade, firm, or product names is for descriptive purposes only and does not imply endorsement by the U.S. Government.

Although this information product, for the most part, is in the public domain, it also may contain copyrighted materials as noted in the text. Permission to reproduce copyrighted items must be secured from the copyright owner.

Suggested citation:

Schulz, K.J., Piatak, N.M., and Papp, J.F., 2017, Niobium and tantalum, chap. M of Schulz, K.J., DeYoung, J.H., Jr., Seal, R.R., II, and Bradley, D.C., eds., Critical mineral resources of the United States-Economic and environmental geology and prospects for future supply: U.S. Geological Survey Professional Paper 1802, p. M1-M34, https://doi.org/ 10.3133/pp1802M.

ISSN 2330-7102 (online) 


\section{Contents}

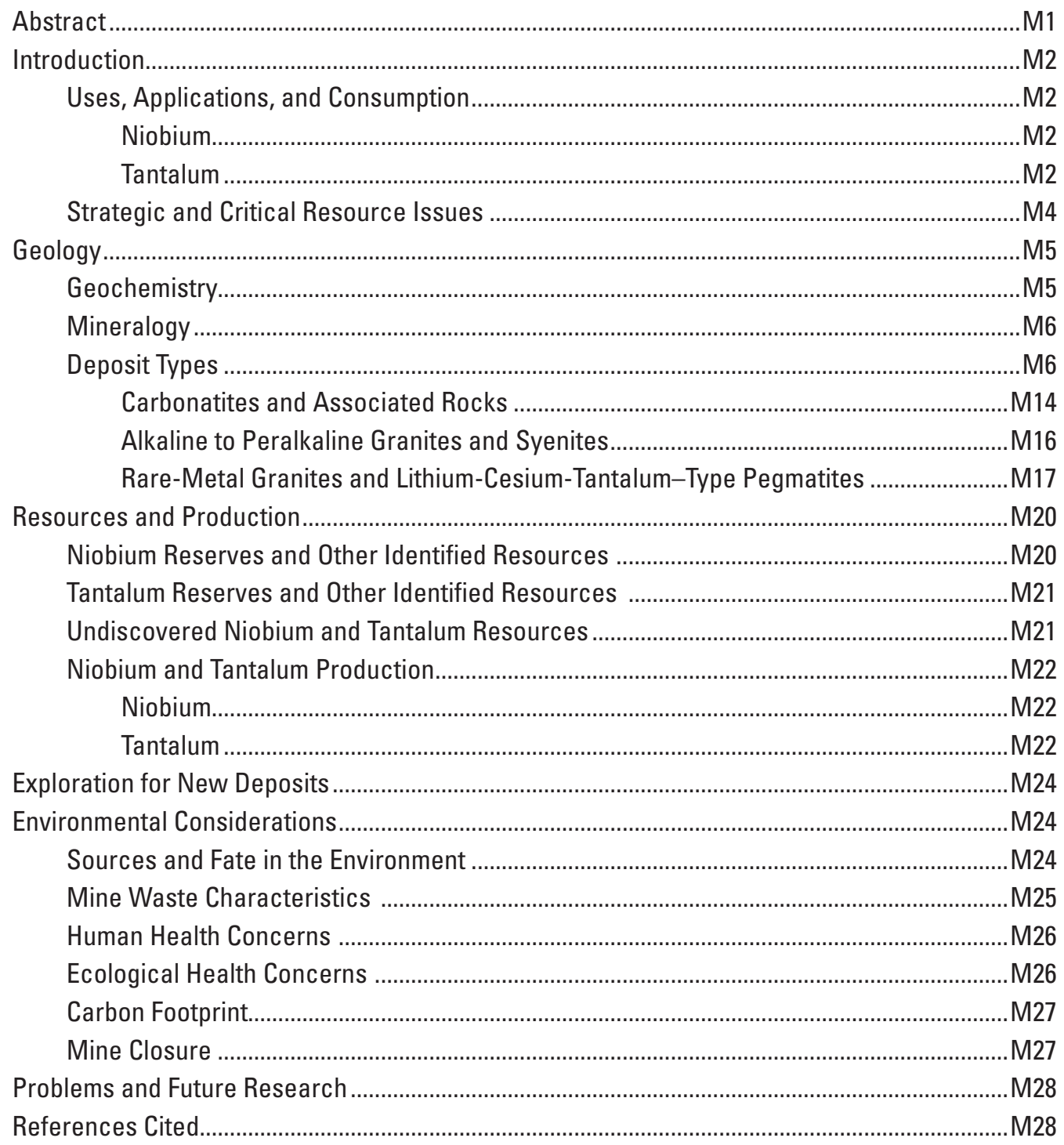




\section{Figures}

M1. Photograph (central view) of the ATLAS detector in the Large Hadron Collider showing its eight superconducting barrel toroid magnets around the calorimeter

M2. Pie charts showing percentage of reported world consumption of niobium and tantalum, by material produced.

M3. Criticality matrix for niobium, tantalum, and selected other mineral commodities

M4. Photographs showing centimeter-size pyrochlore crystals from Uganda, and a tantalite crystal

M5. World map showing locations of selected niobium and tantalum mines, deposits, and occurrences, by deposit type

M6. Log-log plots of deposit grades and tonnages of tantalum and niobium, by deposit type

M7. Diagrams showing the subsurface geology of the Saint-Honoré carbonatite complex in southern Quebec, Canada, and a schematic north-south crosssection along line $A-A^{\prime}$ in $A$.

M8. Schematic cross-section of the Lovozero alkaline intrusion, Kola Peninsula, Russia, showing the relation among the three intrusive phases and the niobium mineralization contained in eudialyte and loparite.

M9. Schematic representation of regional lithium-cesium-tantalum rare-metalbearing pegmatite zoning above a parental granite

M10. Schematic cross-section of a concentrically zoned lithium-cesium-tantalum rare-metal-bearing pegmatite

M11. Bar chart showing niobium resources and reserves in Brazil, Canada, and the United States.

M12. Bar chart showing global tantalum resources and reserves.

M13. Bar charts showing global mine production of niobium and tantalum, from 2000 to 2011.

M14. Pie charts showing percentage of average annual world production of niobium and tantalum, for the period $2007-11$, by country.

\section{Tables}

M1. Selected properties of niobium and tantalum

M2. Selected niobium and tantalum oxide minerals and their end-member $\mathrm{Nb}_{2} \mathrm{O}_{5}$ and $\mathrm{Ta}_{2} \mathrm{O}_{5}$ contents or compositional range

M3. Major types of niobium and tantalum deposits, with key characteristics and examples.

M4. Location, grade, tonnage, and other data for selected niobium-tantalum deposits of the world. 


\section{Conversion Factors}

International System of Units to Inch/Pound

\begin{tabular}{|c|c|c|}
\hline Multiply & By & To obtain \\
\hline \multicolumn{3}{|c|}{ Length } \\
\hline angstrom $(\AA)$ (0.1 nanometer) & 0.003937 & microinch \\
\hline angstrom $(\AA)$ (0.1 nanometer) & 0.000003937 & mil \\
\hline micrometer $(\mu \mathrm{m})$ [or micron] & 0.03937 & mil \\
\hline millimeter (mm) & 0.03937 & inch (in.) \\
\hline centimeter $(\mathrm{cm})$ & 0.3937 & inch (in.) \\
\hline meter $(\mathrm{m})$ & 3.281 & foot $(\mathrm{ft})$ \\
\hline meter $(\mathrm{m})$ & 1.094 & yard (yd) \\
\hline kilometer $(\mathrm{km})$ & 0.6214 & mile (mi) \\
\hline \multicolumn{3}{|c|}{ Area } \\
\hline hectare (ha) & 2.471 & acre \\
\hline square kilometer $\left(\mathrm{km}^{2}\right)$ & 247.1 & acre \\
\hline square meter $\left(\mathrm{m}^{2}\right)$ & 10.76 & square foot $\left(\mathrm{ft}^{2}\right)$ \\
\hline square centimeter $\left(\mathrm{cm}^{2}\right)$ & 0.1550 & square inch $\left(\mathrm{ft}^{2}\right)$ \\
\hline square kilometer $\left(\mathrm{km}^{2}\right)$ & 0.3861 & square mile $\left(\mathrm{mi}^{2}\right)$ \\
\hline \multicolumn{3}{|c|}{ Volume } \\
\hline milliliter (mL) & 0.03381 & ounce, fluid (fl. oz) \\
\hline liter (L) & 33.81402 & ounce, fluid (fl. oz) \\
\hline liter (L) & 1.057 & quart (qt) \\
\hline liter (L) & 0.2642 & gallon (gal) \\
\hline cubic meter $\left(\mathrm{m}^{3}\right)$ & 264.2 & gallon (gal) \\
\hline cubic centimeter $\left(\mathrm{cm}^{3}\right)$ & 0.06102 & cubic inch $\left(\mathrm{in}^{3}\right)$ \\
\hline cubic meter $\left(\mathrm{m}^{3}\right)$ & 1.308 & cubic yard $\left(\mathrm{yd}^{3}\right)$ \\
\hline cubic kilometer $\left(\mathrm{km}^{3}\right)$ & 0.2399 & cubic mile $\left(\mathrm{mi}^{3}\right)$ \\
\hline \multicolumn{3}{|c|}{ Mass } \\
\hline microgram $(\mu \mathrm{g})$ & 0.00000003527 & ounce, avoirdupois (oz) \\
\hline milligram (mg) & 0.00003527 & ounce, avoirdupois (oz) \\
\hline $\operatorname{gram}(\mathrm{g})$ & 0.03527 & ounce, avoirdupois (oz) \\
\hline $\operatorname{gram}(\mathrm{g})$ & 0.03215075 & ounce, troy \\
\hline kilogram (kg) & 32.15075 & ounce, troy \\
\hline kilogram (kg) & 2.205 & pound avoirdupois (lb) \\
\hline ton, metric $(\mathrm{t})$ & 1.102 & ton, short $[2,000 \mathrm{lb}]$ \\
\hline ton, metric $(\mathrm{t})$ & 0.9842 & ton, long $[2,240 \mathrm{lb}]$ \\
\hline \multicolumn{3}{|c|}{ Deposit grade } \\
\hline gram per metric ton $(\mathrm{g} / \mathrm{t})$ & 0.0291667 & ounce per short ton $(2,000 \mathrm{lb})(\mathrm{oz} / \mathrm{T})$ \\
\hline \multicolumn{3}{|c|}{ Pressure } \\
\hline megapascal (MPa) & 10 & bar \\
\hline gigapascal (GPa) & 10,000 & bar \\
\hline \multicolumn{3}{|c|}{ Density } \\
\hline gram per cubic centimeter $\left(\mathrm{g} / \mathrm{cm}^{3}\right)$ & 62.4220 & pound per cubic foot $\left(\mathrm{lb} / \mathrm{ft}^{3}\right)$ \\
\hline milligram per cubic meter $\left(\mathrm{mg} / \mathrm{m}^{3}\right)$ & 0.00000006243 & pound per cubic foot $\left(\mathrm{lb} / \mathrm{ft}^{3}\right)$ \\
\hline \multicolumn{3}{|c|}{ Energy } \\
\hline joule $(J)$ & 0.0000002 & kilowatthour (kWh) \\
\hline joule $(J)$ & $6.241 \times 10^{18}$ & electronvolt (eV) \\
\hline joule (J) & 0.2388 & calorie (cal) \\
\hline kilojoule (kJ) & 0.0002388 & kilocalorie (kcal) \\
\hline
\end{tabular}


International System of Units to Inch/Pound - Continued

\begin{tabular}{|c|c|c|}
\hline Multiply & By & To obtain \\
\hline \multicolumn{3}{|c|}{ Radioactivity } \\
\hline becquerel (Bq) & 0.00002703 & microcurie $(\mu \mathrm{Ci})$ \\
\hline kilobecquerel (kBq) & 0.02703 & microcurie $(\mu \mathrm{Ci})$ \\
\hline \multicolumn{3}{|c|}{ Electrical resistivity } \\
\hline ohm meter $(\Omega-\mathrm{m})$ & 39.37 & ohm inch $(\Omega$-in.) \\
\hline ohm-centimeter $(\Omega$-cm) & 0.3937 & ohm inch $(\Omega$-in. $)$ \\
\hline \multicolumn{3}{|c|}{ Thermal conductivity } \\
\hline $\begin{array}{l}\text { watt per centimeter per degree } \\
\text { Celsius (watt } / \mathrm{cm}^{\circ} \mathrm{C} \text { ) }\end{array}$ & 693.1798 & $\begin{array}{l}\text { International British thermal unit } \\
\text { inch per hour per square foot per } \\
\text { degree Fahrenheit (Btu in } / \mathrm{h} \mathrm{ft}^{2}{ }^{\circ} \mathrm{F} \text { ) }\end{array}$ \\
\hline watt per meter kelvin $(\mathrm{W} / \mathrm{m}-\mathrm{K})$ & 6.9318 & $\begin{array}{l}\text { International British thermal unit } \\
\text { inch per hour per square foot per } \\
\left.\text { degree Fahrenheit (Btu in } / \mathrm{h} \mathrm{ft}^{2}{ }^{\circ} \mathrm{F}\right)\end{array}$ \\
\hline
\end{tabular}

Inch/Pound to International System of Units

\begin{tabular}{lcl}
\hline & Length & \\
\hline mil & 25.4 & micrometer $(\mu \mathrm{m})$ [or micron] \\
inch (in.) & 2.54 & centimeter $(\mathrm{cm})$ \\
inch (in.) & 25.4 & millimeter $(\mathrm{mm})$ \\
foot (ft) & 0.3048 & meter $(\mathrm{m})$ \\
mile (mi) & 1.609 & kilometer $(\mathrm{km})$ \\
\hline & Volume & \\
\hline ounce, fluid (fl. oz) & 29.57 & milliliter $(\mathrm{mL})$ \\
ounce, fluid $(\mathrm{fl} . \mathrm{oz})$ & 0.02957 & liter $(\mathrm{L})$ \\
\hline & Mass & \\
\hline ounce, avoirdupois $(\mathrm{oz})$ & $28,350,000$ & microgram \\
ounce, avoirdupois $(\mathrm{oz})$ & 28,350 & milligram \\
ounce, avoirdupois $(\mathrm{oz})$ & 28.35 & gram $(\mathrm{g})$ \\
ounce, troy & 31.10348 & gram $(\mathrm{g})$ \\
ounce, troy & 0.03110348 & kilogram $(\mathrm{kg})$ \\
pound, avoirdupois $(\mathrm{lb})$ & 0.4536 & kilogram $(\mathrm{kg})$ \\
ton, short $(2,000 \mathrm{lb})$ & 0.9072 & ton, metric $(\mathrm{t})$ \\
ton, long $(2,240 \mathrm{lb})$ & 1.016 & ton, metric $(\mathrm{t})$ \\
\hline & Deposit grade & \\
\hline ounce per short ton $(2,000 \mathrm{lb})(\mathrm{oz} / \mathrm{T})$ & 34.285714 & gram per metric ton $(\mathrm{g} / \mathrm{t})$ \\
\hline & Energy & \\
\hline kilowatthour $(\mathrm{kWh})$ & $37,000,000$ & joule $(\mathrm{J})$ \\
electronvolt $(\mathrm{eV})$ & $1.602 \times 10^{-19}$ & joule $(\mathrm{J})$ \\
\hline & Radioactivity & \\
\hline microcurie $(\mu \mathrm{Ci})$ & becquerel $(\mathrm{Bq})$ \\
microcurie $(\mu \mathrm{Ci})$ & kilobecquerel $(\mathrm{kBq})$ \\
\hline & & \\
\hline
\end{tabular}

Temperature in degrees Celsius $\left({ }^{\circ} \mathrm{C}\right)$ may be converted to degrees Fahrenheit $\left({ }^{\circ} \mathrm{F}\right)$ as follows:

${ }^{\circ} \mathrm{F}=\left(1.8 \times{ }^{\circ} \mathrm{C}\right)+32$

Temperature in degrees Celsius $\left({ }^{\circ} \mathrm{C}\right)$ may be converted to kelvin $(\mathrm{K})$ as follows:

$$
\mathrm{K}={ }^{\circ} \mathrm{C}+273.15
$$

Temperature in degrees Fahrenheit $\left({ }^{\circ} \mathrm{F}\right)$ may be converted to degrees Celsius $\left({ }^{\circ} \mathrm{C}\right)$ as follows:

$$
{ }^{\circ} \mathrm{C}=\left({ }^{\circ} \mathrm{F}-32\right) / 1.8
$$




\section{Datum}

Unless otherwise stated, vertical and horizontal coordinate information is referenced to the World Geodetic System of 1984 (WGS 84). Altitude, as used in this report, refers to distance above the vertical datum.

\section{Supplemental Information}

Specific conductance is given in microsiemens per centimeter at 25 degrees Celsius $(\mu \mathrm{S} / \mathrm{cm}$ at $\left.25^{\circ} \mathrm{C}\right)$.

Concentrations of chemical constituents in soils and (or) sediment are given in milligrams per kilogram (mg/kg), parts per million (ppm), or parts per billion (ppb).

Concentrations of chemical constituents in water are given in milligrams per liter (mg/L), micrograms per liter $(\mu \mathrm{g} / \mathrm{L})$, nanogams per liter $(\mathrm{ng} / \mathrm{L})$, nanomoles per kilogram $(\mathrm{nmol} / \mathrm{kg})$, parts per million (ppm), parts per billion (ppb), or parts per trillion (ppt).

Concentrations of suspended particulates in water are given in micrograms per gram $(\mu \mathrm{g} / \mathrm{g})$, milligrams per kilogram $(\mathrm{mg} / \mathrm{kg})$, or femtograms per gram $(\mathrm{fg} / \mathrm{g})$.

Concentrations of chemicals in air are given in units of the mass of the chemical (milligrams, micrograms, nanograms, or picograms) per volume of air (cubic meter).

Activities for radioactive constituents in air are given in microcuries per milliliter $(\mu \mathrm{Ci} / \mathrm{mL})$.

Deposit grades are commonly given in percent, grams per metric ton $(\mathrm{g} / \mathrm{t})$ - which is equivalent to parts per million (ppm) —or troy ounces per short ton (oz/T).

Geologic ages are expressed in mega-annum (Ma, million years before present, or $10^{6}$ years ago) or giga-annum ( $\mathrm{Ga}$, billion years before present, or $10^{9}$ years ago).

For ranges of years, "to" and (or) the en dash ("-") mean "up to and including."

\begin{tabular}{ll}
\multicolumn{1}{c}{ Concentration unit } & \multicolumn{1}{c}{ Equals } \\
\hline milligram per kilogram $(\mathrm{mg} / \mathrm{kg})$ & part per million \\
microgram per gram $(\mu \mathrm{g} / \mathrm{g})$ & part per million \\
microgram per kilogram $(\mu \mathrm{g} / \mathrm{kg})$ & part per billion $\left(10^{9}\right)$ \\
\hline
\end{tabular}

\section{Equivalencies}

part per million (ppm): $1 \mathrm{ppm}=1,000 \mathrm{ppb}=1,000,000 \mathrm{ppt}=0.0001$ percent part per billion $(\mathrm{ppb}): 0.001 \mathrm{ppm}=1 \mathrm{ppb}=1,000 \mathrm{ppt}=0.0000001$ percent part per trillion (ppt): $0.000001 \mathrm{ppm}=0.001 \mathrm{ppb}=1 \mathrm{ppt}=0.0000000001$ percent

\section{Metric system prefixes}

$\begin{array}{lll}\text { tera- (T-) } & 10^{12} & 1 \text { trillion } \\ \text { giga- (G-) } & 10^{9} & 1 \text { billion } \\ \text { mega- (M-) } & 10^{6} & 1 \text { million } \\ \text { kilo- (k-) } & 10^{3} & 1 \text { thousand } \\ \text { hecto- (h-) } & 10^{2} & 1 \text { hundred } \\ \text { deka- (da-) } & 10 & 1 \text { ten } \\ \text { deci- (d-) } & 10^{-1} & 1 \text { tenth } \\ \text { centi- (c-) } & 10^{-2} & 1 \text { hundredth } \\ \text { milli- (m-) } & 10^{-3} & 1 \text { thousandth } \\ \text { micro- }(\mu-) & 10^{-6} & 1 \text { millionth } \\ \text { nano- (n-) } & 10^{-9} & 1 \text { billionth } \\ \text { pico- (p-) } & 10^{-12} & 1 \text { trillionth } \\ \text { femto- (f-) } & 10^{-15} & 1 \text { quadrillionth } \\ \text { atto- (a-) } & 10^{-18} & 1 \text { quintillionth }\end{array}$




\section{Abbreviations and Symbols}

${ }^{\circ} \mathrm{C}$
$\AA$
$\mathrm{Bq} / \mathrm{kg}$
$\mathrm{CBMM}$
Congo (Kinshasa)
HFSE
$\mathrm{kBq} / \mathrm{kg}$
$\mathrm{km}$
$\mathrm{km}{ }^{2}$
$\mathrm{LCT}$
$\mathrm{m}$
$\mathrm{Ma}$
$\mathrm{mg} / \mathrm{m}^{3}$
$\mathrm{MRI}$
$\mathrm{NMRI}$
$\mathrm{OSHA}$
$\mathrm{ppm}$
$\mathrm{ppt}$
$\mathrm{REE}$

degree Celsius

angstrom

becquerel per kilogram

Companhia Brasileira de Metalurgia e Mineração

Democratic Republic of the Congo

high-field-strength element

kilobecquerel per kilogram

kilometer

square kilometer

lithium-cesium-tantalum

meter

mega-annum

milligram per cubic meter

magnetic resonance imaging

nuclear magnetic resonance instruments

Occupational Safety and Health Administration

part per million

part per trillion

rare-earth element 


\title{
Niobium and Tantalum
}

\author{
By Klaus J. Schulz, Nadine M. Piatak, and John F. Papp
}

\section{Abstract}

Niobium and tantalum are transition metals that are almost always found together in nature because they have very similar physical and chemical properties. Their properties of hardness, conductivity, and resistance to corrosion largely determine their primary uses today. The leading use of niobium (about 75 percent) is in the production of highstrength steel alloys used in pipelines, transportation infrastructure, and structural applications. Electronic capacitors are the leading use of tantalum for high-end applications, including cell phones, computer hard drives, and such implantable medical devices as pacemakers. Niobium and tantalum are considered critical and strategic metals based on the potential risks to their supply (because current production is restricted to only a few countries) and the significant effects that a restriction in supply would have on the defense, energy, high-tech industrial, and medical sectors.

The average abundance of niobium and tantalum in bulk continental crust is relatively low -8.0 parts per million (ppm) niobium and $0.7 \mathrm{ppm}$ tantalum. Their chemical characteristics, such as small ionic size and high electronic field strength, significantly reduce the potential for these elements to substitute for more common elements in rockforming minerals and make niobium and tantalum essentially immobile in most aqueous solutions. Niobium and tantalum do not occur naturally as pure metals but are concentrated in a variety of relatively rare oxide and hydroxide minerals, as well as in a few rare silicate minerals. Niobium is primarily derived from the complex oxide minerals of the pyrochlore group $\left((\mathrm{Na}, \mathrm{Ca}, \mathrm{Ce})_{2}(\mathrm{Nb}, \mathrm{Ti}, \mathrm{Ta})_{2}(\mathrm{O}, \mathrm{OH}, \mathrm{F})_{7}\right)$, which are found in some alkaline granite-syenite complexes (that is, igneous rocks containing sodium- or potassium-rich minerals and little or no quartz) and carbonatites (that is, igneous rocks that are more than 50 percent composed of primary carbonate minerals, by volume). Tantalum is derived mostly from the mineral tantalite $\left((\mathrm{Fe}, \mathrm{Mn})(\mathrm{Ta}, \mathrm{Nb})_{2} \mathrm{O}_{6}\right)$, which is found as an accessory mineral in rare-metal granites and pegmatites that are also enriched in lithium and cesium (termed lithium-cesium-tantalum (LCT)type pegmatites).

Brazil and Canada are the leading nations that produce niobium mineral concentrates, but Brazil is by far the leading producer, accounting for about 90 percent of production, which comes mostly from weathered material derived from carbonatites. Brazil and Canada also have the largest identified niobium resources; additional resources, although they are less well reported, occur in Angola, Australia, China, Greenland, Malawi, Russia, and South Africa. Australia and Brazil have been the leading producers of tantalum mineral concentrates, although recently Ethiopia and Mozambique have also been significant suppliers of tantalum. Artisanal mining of columbite-tantalite (also called coltan) is practiced in many countries, particularly Burundi, the Democratic Republic of the Congo (Congo [Kinshasa]), Nigeria, Rwanda, and Uganda. Brazil has about 40 percent of the identified tantalum resources; other countries and regions with identified tantalum resources include, in decreasing order of resources, Australia, Asia, Russia and the Middle East, Africa, North America, and Europe. Identified niobium and tantalum resources in the United States are small, low grade, and difficult to recover and process, and are thus not commercially recoverable at current prices. Consequently, the United States meets its current and expected future needs for niobium and tantalum through imports of mineral concentrates and alloys and through recovery from foreign and domestic alloy scrap that contain the metals.

Environmentally, the main issues related to niobium and tantalum mining are land disruptions, the volume of waste materials and their disposal, and the radioactivity of some tailings and waste materials that contain thorium and uranium. Because of the relative biological inertness of niobium and tantalum, human and ecological health concerns are generally minimal under most natural conditions.

Demand for both niobium and tantalum is expected to increase as the world economy continues to recover from the downturn that began in 2008. Increased demand for niobium is linked to increased consumption of microalloyed steel, which is used in the manufacture of cars, buildings, ships, and refinery equipment. Demand for these steels will likely increase with continued economic development in such countries as Brazil, China, and India. In addition, increased global demand for cars, cell phones, computers, superconducting magnets, and other high-tech devices will likely spur increased demand for both niobium and tantalum. The estimated global reserves and 
resources of niobium and tantalum are large and appear more than sufficient to meet global demand for the foreseeable future, possibly the next 500 years. The sale of "conflict coltan" attributed to rebel forces waging a civil war in Congo (Kinshasa) has been of recent concern and has highlighted the need for a transparent and traceable global supply chain that can exclude illegal columbite-tantalite from the conventional market while discerning legitimate artisanal mine production in central Africa.

\section{Introduction}

Niobium $(\mathrm{Nb})$ and tantalum $(\mathrm{Ta})$ are transition metals that are very similar in their physical and chemical properties (table M1). They are almost always found together in nature. Both are named after tragic figures from Greek mythologyNiobium is named after Niobe, and tantalum is named after Niobe's father, Tantalus. Niobium was first discovered in 1801 by English chemist Charles Hatchett, who named it columbium after Columbia, the poetic name for North America. Columbium was used interchangeably with niobium until 1949 when niobium was officially accepted as the designated name by the International Union of Pure and Applied Chemistry. Tantalum was first discovered by Swedish scientist Anders Ekeberg in 1802, but because it was difficult to separate from niobium, tantalum was confused with niobium until 1864, when it was confirmed to be a separate element. Relatively pure tantalum metal was not produced until 1903.

Niobium is a lustrous, gray, ductile metal with a high melting point, relatively low density, and superconductor properties. Tantalum is a dark blue-gray, dense, ductile, very hard, and easily fabricated metal. It is highly conductive to heat and electricity and is renowned for its resistance to corrosion by acids. It is these special properties, especially hardness, conductivity, and resistance to corrosion, that determine the primary uses of niobium and tantalum today (table M1).

Table M1. Selected properties of niobium and tantalum.

[Source: Winter (2014). Å, angstrom; ${ }^{\circ} \mathrm{C}$, degree Celsius; $\mathrm{g} / \mathrm{cm}^{3}$, gram per cubic centimeter; $\mathrm{n} \Omega-\mathrm{m}$, nano ohm-meter]

\begin{tabular}{lcc}
\multicolumn{1}{c}{ Property } & Niobium (Nb) & Tantalum (Ta) \\
\hline Atomic number & 41 & 73 \\
\hline Atomic weight & 92.90638 & 180.94788 \\
\hline Atomic radius $(\AA)$ & 1.46 & 1.46 \\
\hline Density $\left(\mathrm{g} / \mathrm{cm}^{3}\right)$ & 8.57 & 16.65 \\
\hline Melting point $\left({ }^{\circ} \mathrm{C}\right)$ & 2,477 & 3,017 \\
\hline $\begin{array}{l}\text { Boiling point }\left({ }^{\circ} \mathrm{C}\right) \\
\text { Hardness }(\text { Mohs scale) }\end{array}$ & 4,744 & 5,458 \\
\hline $\begin{array}{l}\text { Electrical resistivity } \\
(\mathrm{n} \Omega \text {-m) }\end{array}$ & 6.0 & 6.5 \\
\hline Crystal structure & $\begin{array}{c}\text { Body-centered } \\
\text { cubic }\end{array}$ & $\begin{array}{c}\text { Body-centered } \\
\text { cubic }\end{array}$ \\
\hline
\end{tabular}

\section{Uses, Applications, and Consumption}

\author{
Niobium
}

The leading use of niobium is in ferrous metallurgy. About 75 percent of world niobium production is used by the steel industry for the production of a variety of steel alloys that contain small amounts of other metals (microalloy and low-alloy steels) to improve corrosion resistance, strength, toughness, and other properties (Papp, 2013b). Niobium acts as a grain refiner and precipitation hardener in high-strength low-alloy and microalloyed steel, simultaneously improving mechanical strength, high-temperature strength, and toughness and improving corrosion resistance. These steels are used in pipelines, transportation, and structural applications (Roskill Information Services Ltd., 2009). Appreciable amounts of niobium are contained in nickel-, cobalt-, and iron-base superalloys used for high-temperature applications, such as jet engine components, gas turbines, rocket subassemblies, turbocharger systems, and heat-resisting and combustion equipment. Niobium alloys are also used in the manufacture of superconducting magnets used in magnetic resonance imaging (MRI) and nuclear magnetic resonance instruments (NMRI), as well as in particle accelerators, such as the Large Hadron Collider in Europe, which contains the world's largest superconducting magnets (fig. M1). A new use of niobium is in a solid niobic acid that acts as a catalyst in the conversion of palm oil to biodiesel (Schwela, 2010). With increased production of biofuels in Brazil and elsewhere, this use of niobium could constitute a significant future market. Niobium's uses are specialized, and substitution is generally likely to result in reduced performance and higher cost.

World consumption of niobium, by material produced, is shown in figure M2A (Schwela, 2011). The greatest consumption is of ferroniobium, which is an iron-niobium alloy that contains 60 to 70 percent niobium. Leading uses of niobium are for steelmaking ( 87 percent), followed by niobium chemicals (5.2 percent), vacuum-grade niobium (2.7 percent), other niobium alloys (2.5 percent), and niobium metal ( 0.9 percent). In 2011, U.S. consumption of niobium (measured as elemental niobium) was 9,160 metric tons, which was an increase of more than 12 percent from consumption in 2010 (Papp, 2013b).

\section{Tantalum}

The electronics industry accounts for about one-half of tantalum consumption, mainly as powder and wire (Schwela, 2010). Electronic capacitors are the leading end use of tantalum owing to tantalum's particular ability to store and release energy. Because of this ability, components can be exceptionally small and are favored in space-sensitive, high-end applications, such as telecommunications (for cell phones), data storage (for hard drives), and implantable medical devices (for hearing aids and pacemakers). To date, 


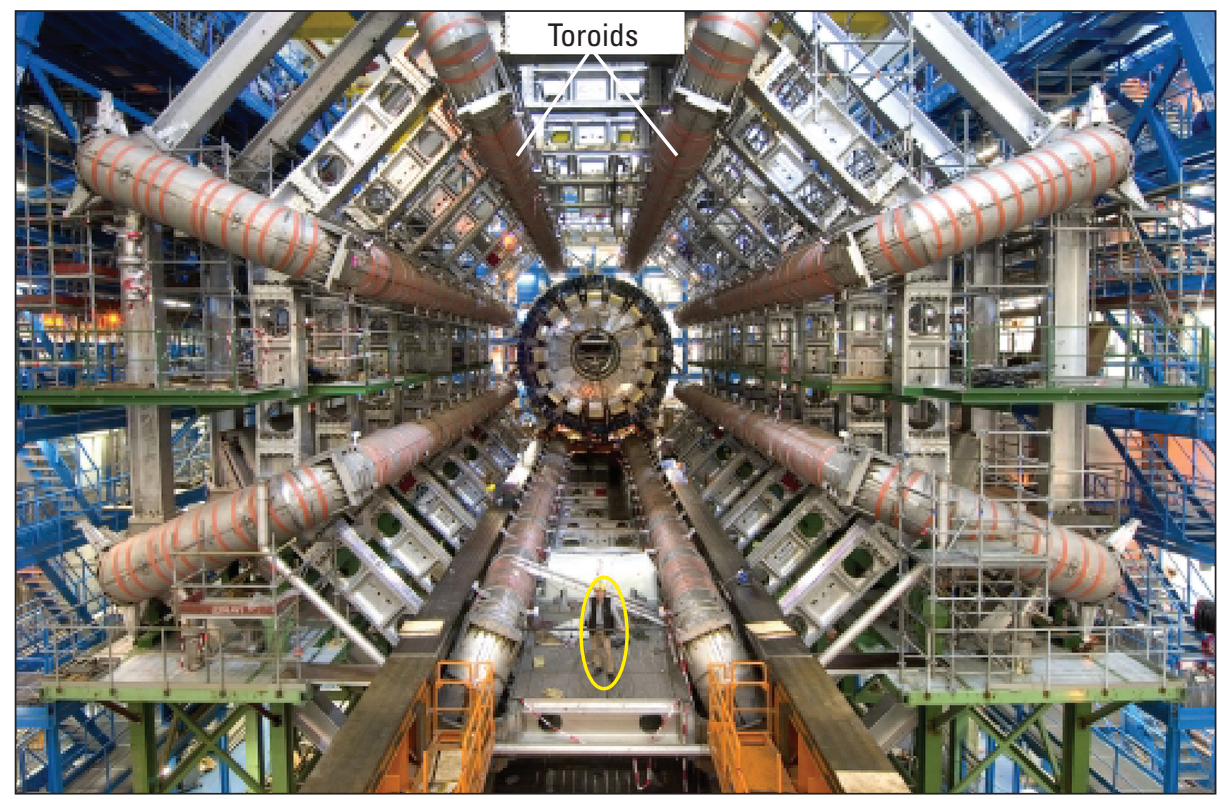

Figure M1. Photograph (central view) of the ATLAS detector in the Large Hadron Collider showing its eight superconducting barrel toroid magnets around the calorimeter. (For scale, note the person [circled] standing in the lower center portion of the photograph.) Together, these toroids make up the world's largest superconducting magnet. Photograph of the ATLAS Experiment Copyright(C) 2014 CERN.

no effective substitute has been found for tantalum in electronic devices without loss in performance. Tantalum's low mechanical strength and high biocompatibility allows it to be used as a coating on stronger substrates, such as stainless steel, for such medical applications as stents to support blood vessels, plates, bone replacements, and suture clips and wire. In addition, tantalum is used to impart strength and high temperature resistance to cracking in the manufacture of superalloys for use in aerospace applications and energy generation. Its resistance to corrosion makes tantalum useful in the chemical industry, generally as a lining to pipes, tanks, and vessels. Tantalum oxide is used to increase the refractive index of lens glass, whereas the hardness of tantalum carbide makes it ideal for cutting tools.

World consumption of tantalum, by material produced, is shown in figure M2B (Schwela, 2011). The leading uses are capacitor-grade tantalum powder (24 percent) and tantalum mill products ( 22 percent) followed by tantalum chemicals (18 percent); metallurgical-grade powder, unwrought metal, scrap, and other uses (17 percent); tantalum ingot (12 percent); and tantalum carbide ( 7 percent). In 2011, U.S. consumption of tantalum (measured as elemental tantalum) was 1,210 metric tons, which was an increase of 4 percent from consumption in 2010 (Papp, 2013c).

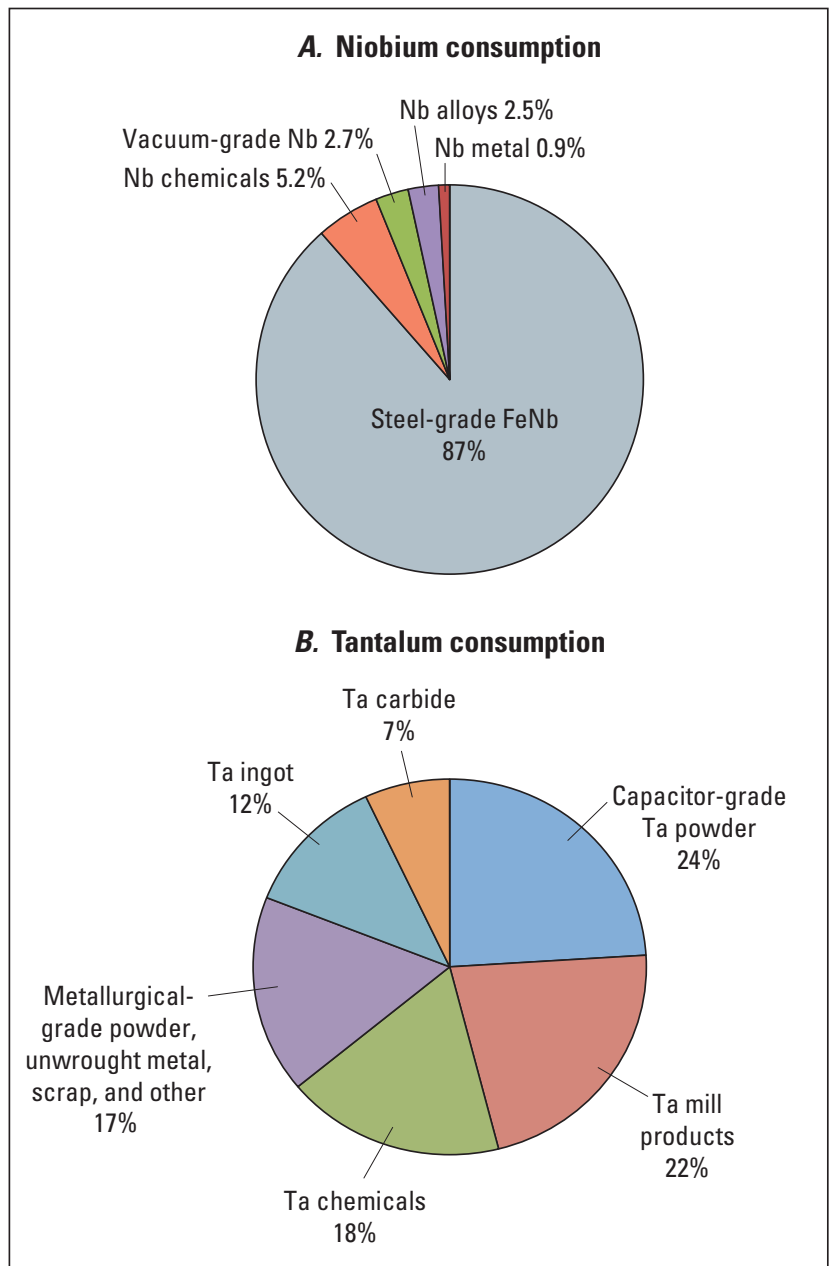

Figure M2. Pie charts showing percentage of reported world consumption of $A$, niobium, and $B$, tantalum, by material produced (Schwela, 2011). Percentages have been rounded to two significant figures and do not add to 100 . FeNb, ferroniobium; Nb, niobium; Ta, tantalum 


\section{Strategic and Critical Resource Issues}

Niobium and tantalum are considered critical and strategic metals owing to their specialized and important applications in the defense, energy, high-tech industrial, and medical sectors; because they are essential in many products and applications but generally have no effective substitutes; and because the mine production of these minerals takes place in only a few countries. The geographic concentration of niobium resources and production, and, to a lesser extent, those of tantalum, make their supply vulnerable to potential influence and disruption by such factors as civil unrest, environmental issues, market manipulation, natural disasters, and political changes. In their evaluation of the criticality of selected mineral commodities, the National Research Council (2008) ranked niobium as one of the most critical minerals, along with manganese, platinumgroup metals (especially rhodium and platinum), and rare-earth elements (REEs), and ranked tantalum as moderately critical based on risks to supply and the potential impact of supply restrictions (fig. M3). In its analysis of critical raw materials for the European Union, the European Commission reached a similar conclusion on the criticality of niobium and tantalum (European Commission, 2010).

The estimated global reserves and resources of both niobium and tantalum are large, but they are unevenly distributed geographically. The United States has had no reported mine production of niobium and tantalum since the late 1950s, and identified resources are mostly of low grade and are considered uneconomic at current commodity prices (Papp, 2013b, c). As a result, the United States has for many years been totally dependent on imports and recycling to meet its niobium and tantalum needs. This chapter gives a geologic perspective of niobium and tantalum resources with the purpose of providing an overview of how, why, and where sources of niobium and tantalum have formed and the geographic distribution of these sources around the world. Also included is a discussion of environmental issues that may derive from current and future niobium and tantalum mining.

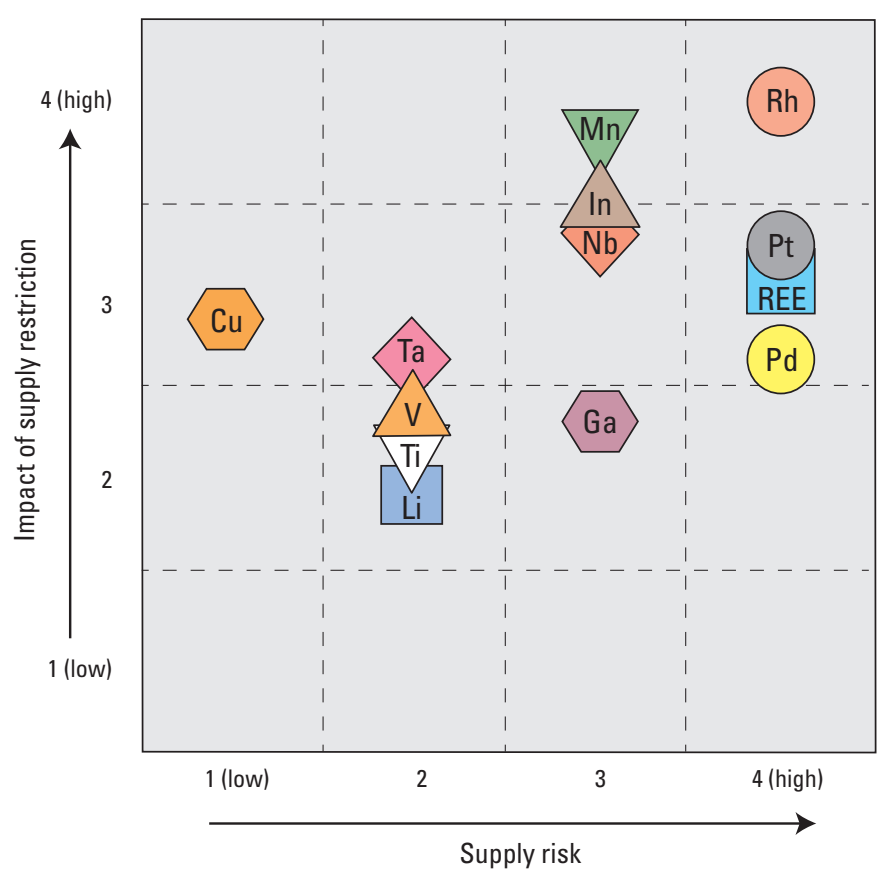

Figure M3. Criticality matrix for niobium, tantalum, and selected other mineral commodities. Of all these commodities, indium, manganese, niobium, platinumgroup metals (palladium, platinum, and rhodium), and rare-earth elements fall into the most critical zone of high supply risk and high impact of supply restriction (after National Research Council, 2008, p. 165). Cu, copper; Ga, gallium; In, indium; Li, lithium; $\mathrm{Mn}$, manganese; $\mathrm{Nb}$, niobium; $\mathrm{Pd}$, palladium; $\mathrm{Pt}$, platinum; REE, rare-earth element(s); Rh, rhodium; Ta, tantalum; Ti, titanium; and V, vanadium 


\section{Geology}

\section{Geochemistry}

Niobium and tantalum generally show strongly coherent geochemical behavior because they are identical in charge ( $5^{+}$under most geologically relevant oxidation conditions) and nearly identical in effective ionic radius (table M1). As a result, they are closely associated and found together in most rocks and minerals in which they occur. Both elements are lithophile, in that they show a strong affinity for oxygen, and they are high-field-strength elements (HFSEs), meaning that their ions are relatively small and have intense electrostatic fields. Their HFSE characteristics significantly reduce their potential to substitute for more common elements in most rock-forming minerals and make them essentially immobile under most natural conditions (Wood, 2005); as a result, their concentrations in the surface environment are generally low. The average abundance of niobium and tantalum in bulk continental crust is 8.0 parts per million (ppm) niobium and 0.7 ppm tantalum (Rudnick and Gao, 2003). In surface waters, concentrations are generally in the low parts per trillion.

Niobium and tantalum are depleted in continental crust relative to other highly incompatible elements (elements that do not readily substitute for more common elements in major rock-forming minerals), such as cesium, rubidium, thorium, and uranium, and the light REEs, including cerium and lanthanum. As a result, continental crustal rocks are typically characterized by high lanthanum to niobium ( $\mathrm{La:Nb})$ ratiosthe average crustal ratio is about 2.5 (Rudnick and Gao, 2003). The depletion of niobium and tantalum in continental crust is attributed to the formation of crustal rocks at convergent margins above subduction zones where titanium-rich minerals that host niobium and tantalum may remain as residual phases in the source region during generation of the magmas (Kelemen and others, 2003).

Although niobium and tantalum generally show coherent geochemical behavior, some chemical processes are able to separate them, which results in preferential enrichment or depletion of one or the other. These processes are still poorly understood, although crystal fractionation during magma evolution is the most commonly invoked mechanism. Niobium and tantalum show limited substitution for tin, tungsten, and zirconium in some rock-forming minerals, but particularly for titanium in such minerals as ilmenite $\left(\mathrm{FeTiO}_{3}\right)$, rutile $\left(\mathrm{TiO}_{2}\right)$, and titanite (sphene) $\left(\mathrm{CaTiSiO}_{5}\right)$. As niobium and tantalum become more highly enriched in residual igneous melts, a variety of chiefly oxide and hydroxide niobium and tantalum minerals may form (see Mineralogy section and table M2), depending on melt composition, temperature, pressure, and fluid composition. In addition, some evidence suggests that later alteration by hydrothermal (hot) fluids - in particular, concentrated fluoride solutions (Wood, 2005) - may play a role in mobilizing and enriching niobium and tantalum.

Table M2. Selected niobium and tantalum oxide minerals and their end-member $\mathrm{Nb}_{2} \mathrm{O}_{5}$ and $\mathrm{Ta}_{2} \mathrm{O}_{5}$ contents or compositional range.

[Data are from Mackay and Simandl (2014) and Parker and Fleischer (1968). $\mathrm{Nb}_{2} \mathrm{O}_{5}$, niobium pentoxide; $\mathrm{Ta}_{2} \mathrm{O}_{5}$, tantalum pentoxide; NP, not present]

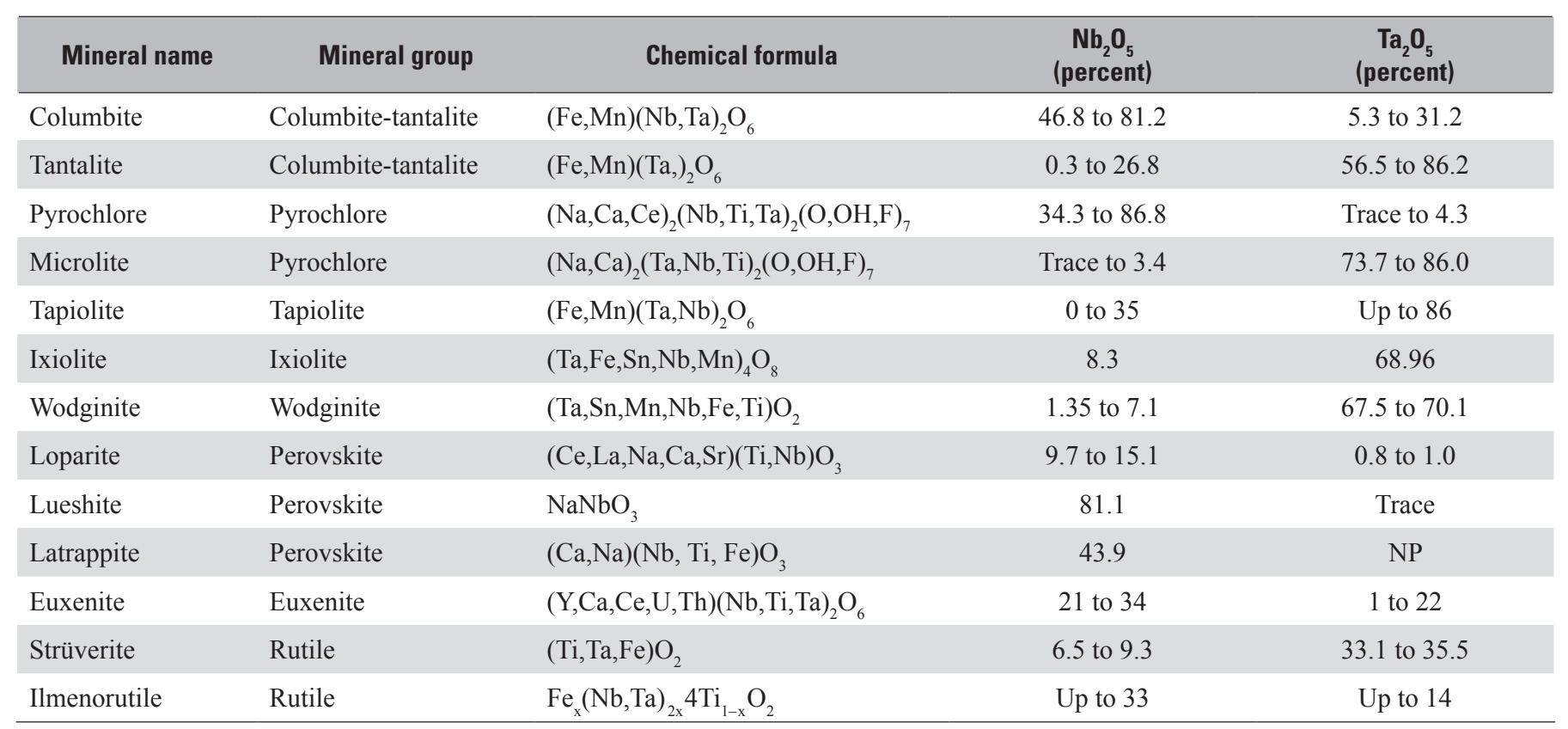




\section{Mineralogy}

Niobium and tantalum do not occur naturally as pure metals, but they are essential components in a variety of oxide and hydroxide minerals, as well as in a few rare silicates and one borate (Parker and Fleischer, 1968). The economically important mineral species are all oxides (table M2); pyrochlore is the principal ore mineral for niobium, and tantalite is the principal ore mineral for tantalum (fig. M4). Until the discovery of pyrochlore-rich deposits in the 1950s, niobium was produced as a byproduct of mining columbite-tantalitebearing pegmatites for tantalum.

The columbite-tantalite mineral group is characterized by a wide range in niobium and tantalum content as well as variable iron and manganese content. Columbite (a niobiumrich mineral) and tantalite (a tantalum-rich mineral) have very similar properties because they have the same structure and similar chemistries, but tantalite has a much higher specific gravity $(8.0+)$ than does columbite (5.2). Tantalite also has a dimorphic relation (same chemistry but different crystal structure) to the mineral tapiolite. Columbite-tantalite minerals are found as accessory phases in rare-metal granites and pegmatites (Černý, 1991a, b).

The pyrochlore mineral group also has a wide compositional range, but generally has niobium greatly enriched over tantalum (a ratio of about 200:1). In addition, pyrochlore can contain significant amounts of barium, light REEs, and uranium. Because it can contain uranium, pyrochlore tends to be radioactive and can show damage to its crystal structure from radiation. Pyrochlore is typically found as a primary mineral in alkaline igneous rocks, particularly carbonatites (for example, the Araxá carbonatite in Brazil).
Other oxide minerals, such as loparite, ixiolite, tapiolite, and the perovskite group (table M2) are less common sources of niobium and tantalum. Loparite concentrate from the Lovozero intrusion in the Kola Peninsula has been a source of niobium in Russia but is not economically competitive with pyrochlore. The calcium- and niobium-dominant perovskite-group mineral latrappite is the main ore mineral at the Oka carbonatite complex in Quebec, Canada. Microlite is the tantalum-rich end member of the pyrochlore mineral group and is generally found in pegmatites in association with columbite-tantalite. The titanium-bearing mineral strüverite has been a low-grade source of tantalum recovered from tin-mining waste in Southeast Asia. Niobium- and tantalumbearing silicate minerals are relatively rare and found mostly in alkaline igneous rocks.

\section{Deposit Types}

Niobium and tantalum minerals are found in a variety of igneous rocks around the world but only rarely in concentrations great enough to be of economic interest. Primary niobium and tantalum mineral deposits are found in three main types of igneous intrusive rocks (table M3; Küster, 2009):

1. Carbonatites and associated alkaline rocks ( $\mathrm{Nb}$ dominant),

2. Alkaline to peralkaline granites and syenites ( $\mathrm{Nb}$ dominant), and

3. Rare-metal granites and pegmatites of the lithiumcesium-tantalum (LCT) family (Ta dominant) (Černý and Ercit, 2005).

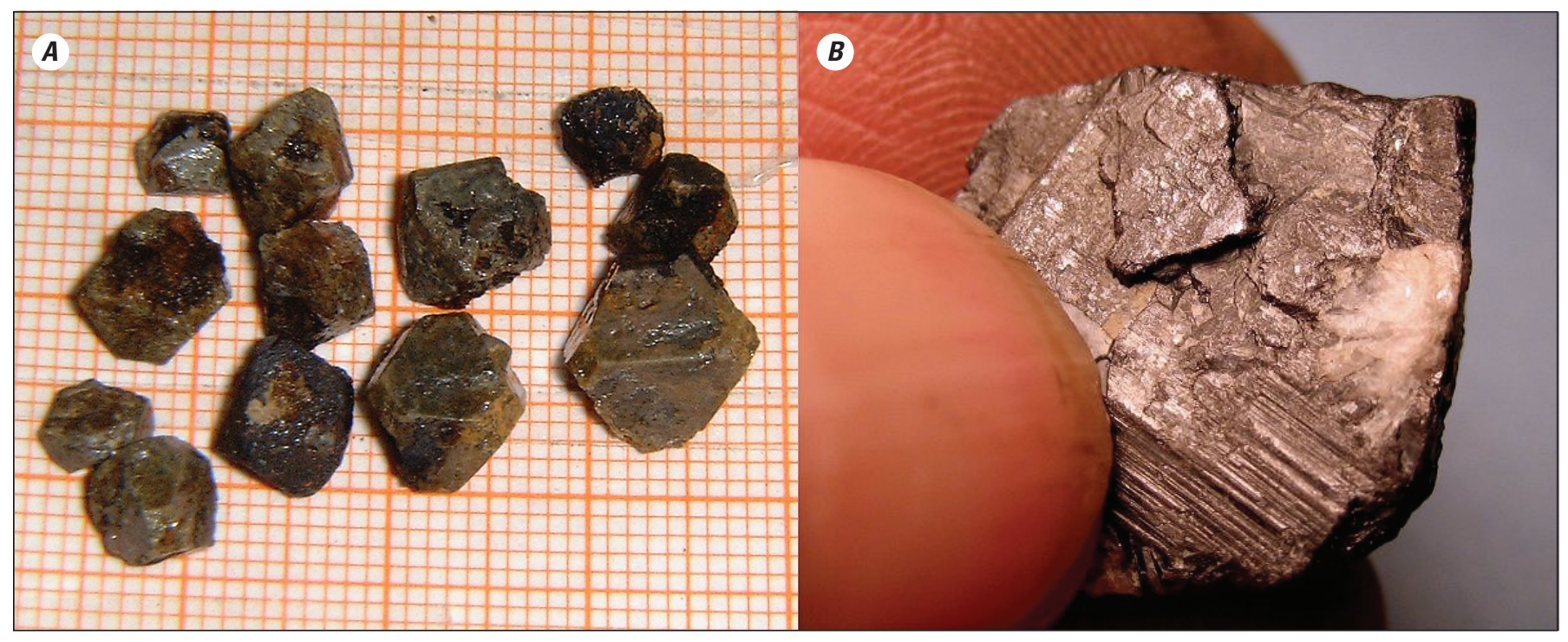

Figure M4. Photographs showing $A$, centimeter-size pyrochlore crystals from Uganda, and $B$, a tantalite crystal. Photograph $A$ is by Gunnar Ries/CC-BY-SA-3.0; photograph $B$ is by Roger Weller, Cochise College. 
In addition, some secondary concentrations have been formed by weathering of primary deposits (laterites) and by sedimentary processes (placers). The secondary deposits are of particular interest because they can be less expensive to mine and can have higher grades than primary hard-rock deposits. Because secondary deposits typically occur in close proximity to their primary sources, they are not described separately below.

Deposits of niobium and tantalum are found around the world (fig. M5, table M4), but major production is currently restricted to only a few countries. Grade and tonnage figures for these deposits are shown in figure M6. Generally, grades for niobium are higher (from about 0.1 to 3.0 percent niobium pentoxide $\left[\mathrm{Nb}_{2} \mathrm{O}_{5}\right]$ ) than those of tantalum (generally $<0.1$ percent tantalum pentoxide $\left[\mathrm{Ta}_{2} \mathrm{O}_{5}\right]$ ). Carbonatites generally have the highest grades and tonnages of niobium, although they overlap with those of alkaline granite and syenite-hosted deposits. In addition, some alkaline graniteand syenite-hosted deposits have higher tonnages at similar grades of tantalum than do rare-metal granite and pegmatitehosted deposits (fig. M6A). The ratios of niobium to tantalum in the alkaline granite and syenite deposits are much higher ( $>10$ to 20 ) because of the predominance of niobium-rich minerals, such as pyrochlore and columbite.

Table M3. Major types of niobium and tantalum deposits, with key characteristics and examples.

[Modified from British Geological Survey (2011). Grades and tonnages are highly variable among deposits, and the grades and tonnages given in this table are generalizations only. LCT, lithium-cesium-tantalum; Mt, million metric tons; $\mathrm{Nb}$, niobium; $\mathrm{Nb}_{2} \mathrm{O}_{5}$, niobium pentoxide; $\mathrm{Ta}$, tantalum; $\mathrm{Ta}_{2} \mathrm{O}_{5}$, tantalum pentoxide]

\begin{tabular}{|c|c|c|c|}
\hline Deposit type & Brief description & Typical grades and tonnage & Major examples \\
\hline $\begin{array}{l}\text { Carbonatite-hosted } \\
\text { primary deposits }\end{array}$ & $\begin{array}{l}\mathrm{Nb}>\text { Ta: Niobium deposits commonly } \\
\text { consisting of members of the } \\
\text { perovskite and pyrochlore mineral } \\
\text { groups found within carbonatite } \\
\text { intrusions in alkaline igneous } \\
\text { provinces }\end{array}$ & $\begin{array}{l}\text { Deposits show a wide range in both } \\
\text { grade and tonnage. Morro dos Seis } \\
\text { Lagos is the largest reported deposit; } \\
\text { it contains about } 2,900 \mathrm{Mt} \text { at a grade } \\
\text { of } 2.85 \text { percent } \mathrm{Nb}_{2} \mathrm{O}_{5} \text {. More typical } \\
\text { is the deposit at } \mathrm{Niobec}_{\text {, which }} \\
\text { contains about } 46 \mathrm{Mt} \text { at a grade } \\
\text { of } 0.53 \text { percent } \mathrm{Nb}_{2} \mathrm{O}_{5}\end{array}$ & $\begin{array}{l}\text { Niobec and Oka, Canada; } \\
\text { Araxá, Catalão I and II, } \\
\text { and Morro dos Seis } \\
\text { Lagos, Brazil }\end{array}$ \\
\hline $\begin{array}{l}\text { Alkaline granite } \\
\text { and syenite }\end{array}$ & $\begin{array}{l}\mathrm{Nb}>\mathrm{Ta} \text { : Deposits containing niobium } \\
\text { and lesser amounts of tantalum; } \\
\text { the deposits are related to silicic } \\
\text { alkaline granite and syenite igneous } \\
\text { intrusions }\end{array}$ & $\begin{array}{l}\text { Generally }<1,000 \mathrm{Mt} \text { at grades of } \\
0.1 \text { to } 1 \text { percent } \mathrm{Nb}_{2} \mathrm{O}_{5} \text { and } \\
<0.05 \text { percent } \mathrm{Ta}_{2} \mathrm{O}_{5}\end{array}$ & $\begin{array}{l}\text { Motzfeldt and Ilímaussaq, } \\
\text { Greenland; Lovozero, } \\
\text { Russia; Thor Lake and } \\
\text { Strange Lake, Canada }\end{array}$ \\
\hline LCT-type pegmatite & $\begin{array}{l}\mathrm{Ta}>\mathrm{Nb} \text { : Deposits containing tantalum } \\
\text { and lesser amounts of niobium; the } \\
\text { deposits are LCT-enriched-type } \\
\text { pegmatites }\end{array}$ & $\begin{array}{l}\text { Generally }<100 \mathrm{Mt} \text { at grades of } \\
\quad<0.05 \mathrm{Ta}_{2} \mathrm{O}_{5}\end{array}$ & $\begin{array}{l}\text { Greenbushes and } \\
\text { Wodgina, Australia; } \\
\text { Tanco, Canada; Volta } \\
\text { Grande, Brazil; } \\
\text { Kenticha, Ethiopia }\end{array}$ \\
\hline $\begin{array}{l}\text { Secondary (regolith) } \\
\text { deposits }\end{array}$ & $\begin{array}{l}\text { Niobium and (or) tantalum ore miner- } \\
\text { als concentrated in zones of intense } \\
\text { weathering above carbonatite and } \\
\text { granite or pegmatite intrusions, or in } \\
\text { sedimentary placer deposits derived } \\
\text { from such intrusions }\end{array}$ & $\begin{array}{l}\text { Lateritic deposits generally have } \\
<1,000 \mathrm{Mt} \text { at grades of up to } \\
3 \text { percent } \mathrm{Nb}_{2} \mathrm{O}_{5} \text {. Placer deposits, } \\
\text { such as the deposit at Tomtor, } \\
\text { can have very high grades of } \\
\text { up to } 12 \text { percent } \mathrm{Nb}_{2} \mathrm{O}_{5}\end{array}$ & $\begin{array}{l}\text { Araxá and Catalão, Brazil; } \\
\text { Tomtor, Russia; Green- } \\
\text { bushes, Australia }\end{array}$ \\
\hline
\end{tabular}




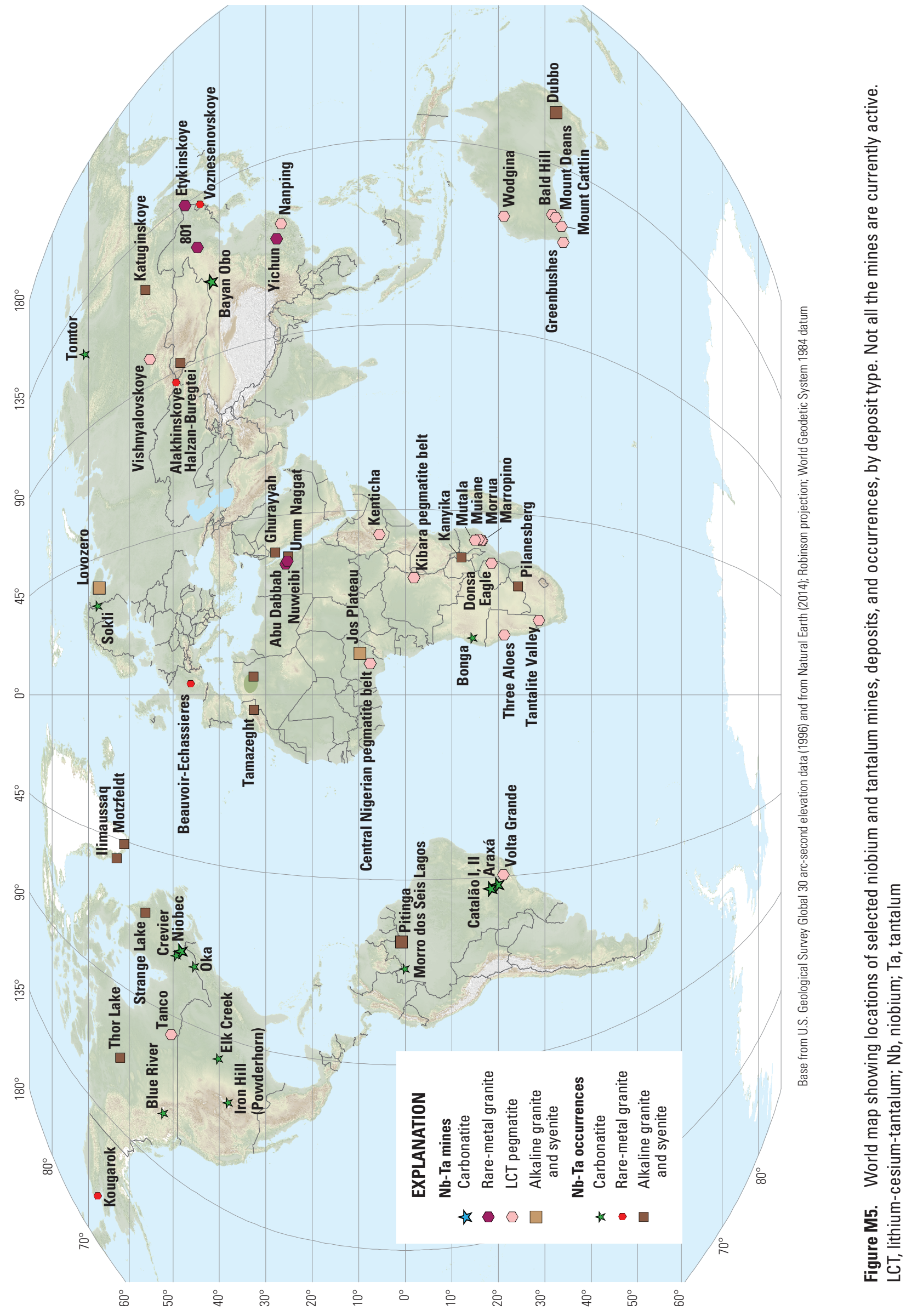



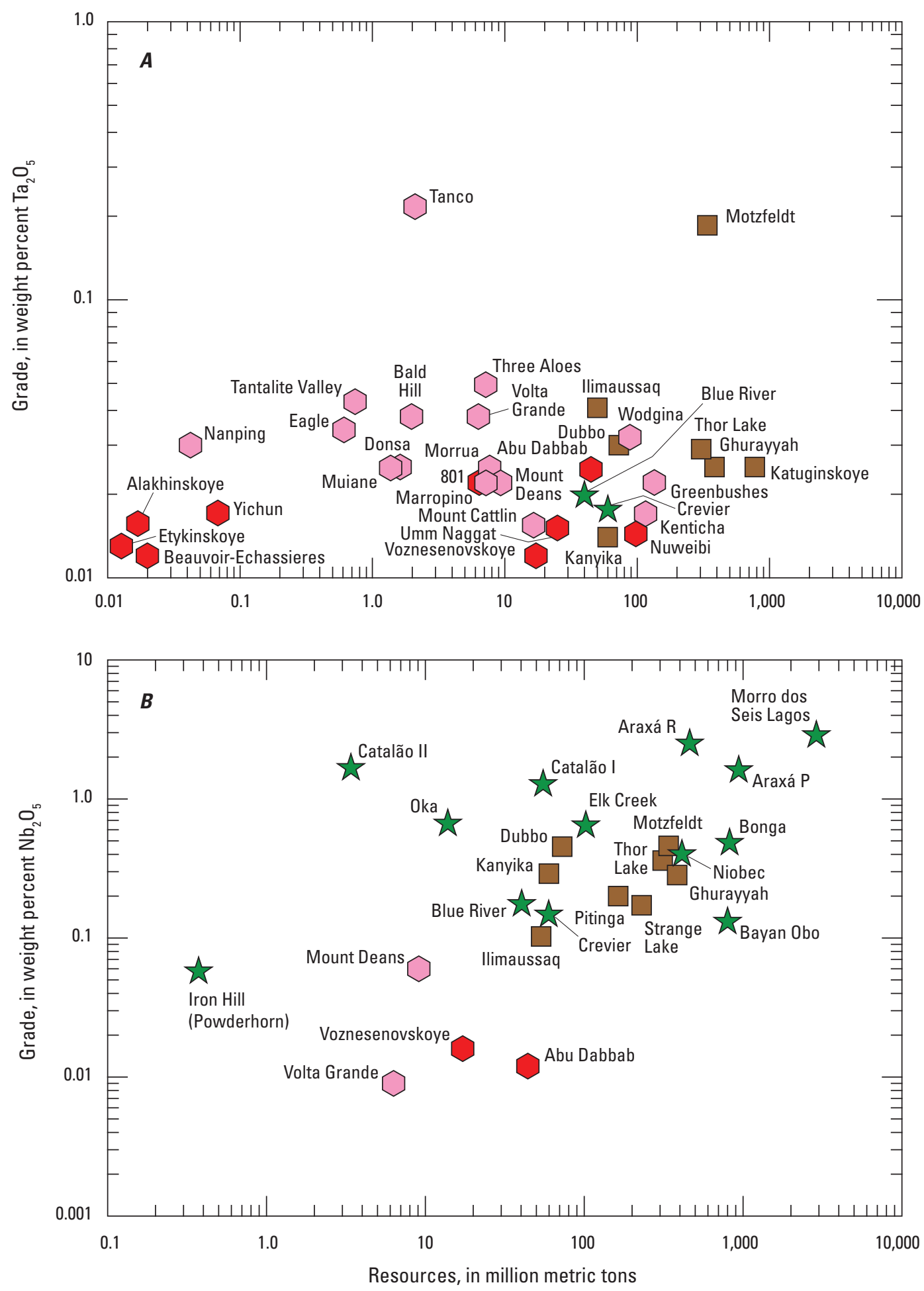

EXPLANATION
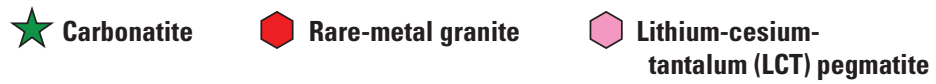

Alkaline granite and syenite

Figure M6. Log-log plots of deposit grades and tonnages of $A$, tantalum, and $B$, niobium, by deposit type. The data include different levels of probability, including measured, indicated, and inferred resources and (or) proven and probable reserves. Data and sources are given in table M4. $P$, primary deposit; $R$, residual deposit, $\mathrm{Nb}_{2} \mathrm{O}_{5^{\prime}}$, niobium pentoxide; $\mathrm{Ta}_{2} \mathrm{O}_{5^{\prime}}$, tantalum pentoxide 
Table M4. Location, grade, tonnage, and other data for selected niobium-tantalum deposits of the world.

[Symbol size (small, large) corresponds to size of symbols shown in figure M5; deposit grade and tonnage are shown graphically in figure M6. Symbol size: S, small; L, large. WGS 84, World Geodetic System of 1984; negative values for latitude indicate that the deposit is in the Southern Hemisphere; negative values for longitude indicate that the deposit is in the Western Hemisphere. $\mathrm{Nb}_{2} \mathrm{O}_{5}$, niobium pentoxide; $\mathrm{Ta}_{2} \mathrm{O}_{5}$, tantalum pentoxide. Resource categories: M+In+If, measured+indicated+inferred; In+If, indicated+inferred. LCT, lithium-cesium-tantalum; Ma, mega-annum; NA, not available]

\begin{tabular}{|c|c|c|c|c|c|}
\hline Deposit & Country & Deposit type & $\begin{array}{l}\text { Symbol } \\
\text { size }\end{array}$ & Latitude & Longitude \\
\hline Bonga & Angola & Carbonatite & $\mathrm{S}$ & -14.27 & 13.97 \\
\hline Bald Hill & Australia & LCT pegmatite & $\mathrm{L}$ & -31.52 & 122.18 \\
\hline Greenbushes & Australia & LCT pegmatite & $\mathrm{L}$ & -33.87 & 116.06 \\
\hline Mount Cattlin & Australia & LCT pegmatite & $\mathrm{L}$ & -33.56 & 120.04 \\
\hline Mount Deans & Australia & LCT pegmatite & $\mathrm{L}$ & -32.31 & 121.79 \\
\hline Wodgina & Australia & LCT pegmatite & $\mathrm{L}$ & -21.18 & 118.68 \\
\hline Dubbo & Australia & $\begin{array}{l}\text { Alkaline granite } \\
\text { and syenite }\end{array}$ & $\mathrm{L}$ & -32.42 & 148.60 \\
\hline Araxá & Brazil & Carbonatite & $\mathrm{L}$ & -19.67 & -46.95 \\
\hline Catalão I & Brazil & Carbonatite & $\mathrm{L}$ & -18.13 & -47.80 \\
\hline Catalão II & Brazil & Carbonatite & $\mathrm{L}$ & -18.03 & -47.87 \\
\hline Volta Grande & Brazil & LCT pegmatite & $\mathrm{L}$ & -21.08 & -44.58 \\
\hline Pitinga & Brazil & $\begin{array}{l}\text { Alkaline granite } \\
\text { and syenite }\end{array}$ & $\mathrm{L}$ & 0.78 & -60.08 \\
\hline Morro dos Seis Lagos & Brazil & Carbonatite & $\mathrm{S}$ & 0.28 & -66.68 \\
\hline Blue River & Canada & Carbonatite & $\mathrm{S}$ & 52.32 & -119.17 \\
\hline Tanco & Canada & LCT pegmatite & $\mathrm{L}$ & 50.43 & -95.45 \\
\hline Thor Lake & Canada & $\begin{array}{l}\text { Alkaline granite } \\
\text { and syenite }\end{array}$ & $\mathrm{S}$ & 62.11 & -112.60 \\
\hline Oka & Canada & Carbonatite & $\mathrm{S}$ & 45.50 & -74.02 \\
\hline Yichun & China & Rare-metal granite & $\mathrm{L}$ & 27.65 & 114.52 \\
\hline Nanping & China & LCT pegmatite & $\mathrm{L}$ & 26.67 & 118.10 \\
\hline 801 & China & Rare-metal granite & $\mathrm{L}$ & 44.62 & 120.97 \\
\hline Bayan Obo & China & Carbonatite & $\mathrm{L}$ & 41.80 & 109.97 \\
\hline $\begin{array}{l}\text { Kibara pegmatite } \\
\text { belt }\end{array}$ & $\begin{array}{l}\text { Democratic Republic of the } \\
\text { Congo and Rwanda }\end{array}$ & LCT pegmatite & $\mathrm{L}$ & -2.00 & 28.00 \\
\hline Abu Dabbab & Egypt & Rare-metal granite & $\mathrm{S}$ & 25.34 & 34.54 \\
\hline Nuweibi & Egypt & Rare-metal granite & $\mathrm{S}$ & 25.20 & 34.50 \\
\hline Umm Naggat & Egypt & Rare-metal granite & $\mathrm{S}$ & 25.20 & 34.50 \\
\hline Kenticha & Ethiopia & LCT pegmatite & $\mathrm{L}$ & 5.52 & 39.03 \\
\hline
\end{tabular}


Table M4. Location, grade, tonnage, and other data for selected niobium-tantalum deposits of the world.-Continued

[Symbol size (small, large) corresponds to size of symbols shown in figure M5; deposit grade and tonnage are shown graphically in figure M6. Symbol size: S, small; L, large. WGS 84, World Geodetic System of 1984; negative values for latitude indicate that the deposit is in the Southern Hemisphere; negative values for longitude indicate that the deposit is in the Western Hemisphere. $\mathrm{Nb}_{2} \mathrm{O}_{5}$, niobium pentoxide; $\mathrm{Ta}_{2} \mathrm{O}_{5}$, tantalum pentoxide. Resource categories: M+In+If, measured+indicated+inferred; In+If, indicated+inferred. LCT, lithium-cesium-tantalum; Ma, mega-annum; NA, not available]

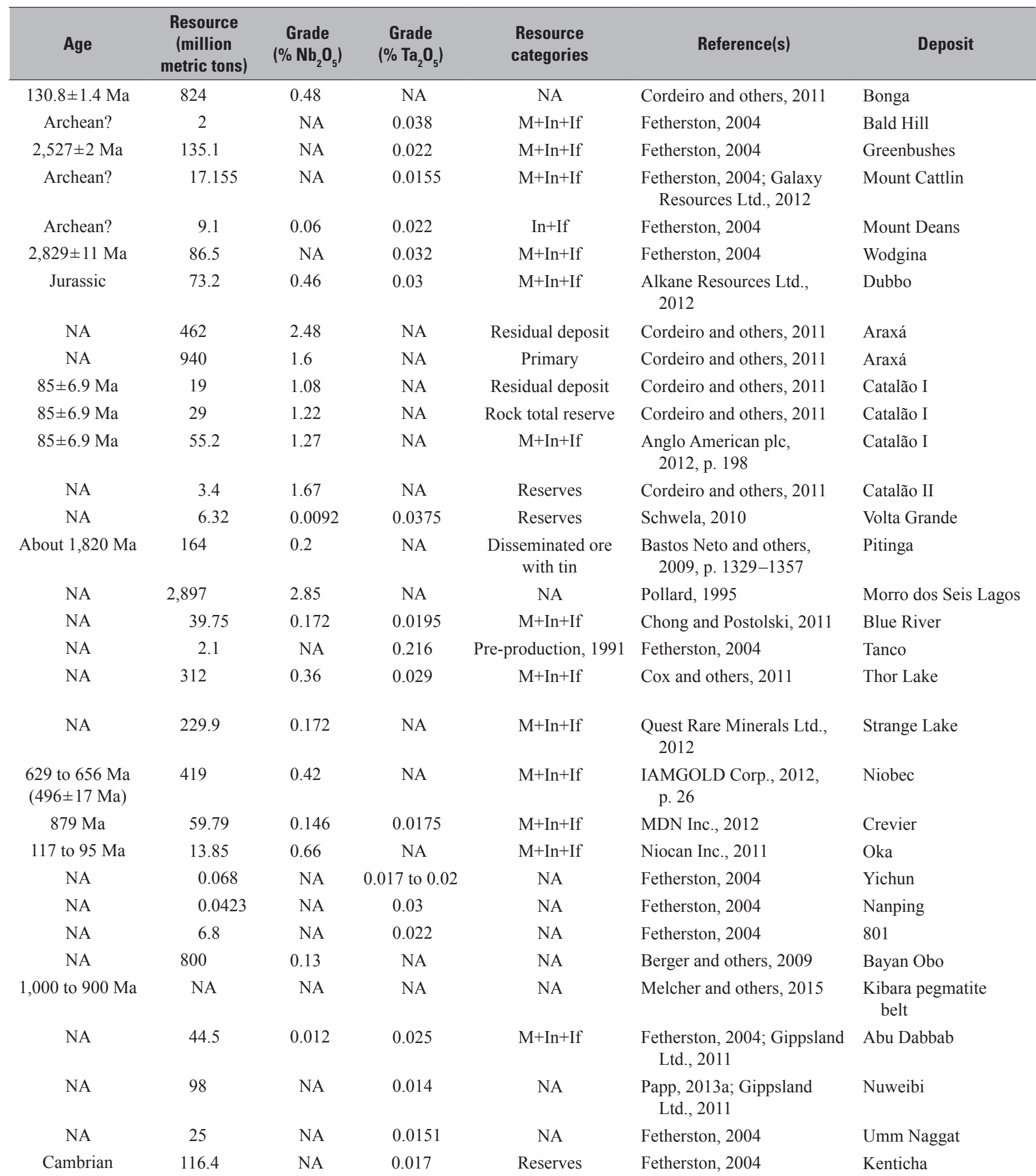


Table M4. Location, grade, tonnage, and other data for selected niobium-tantalum deposits of the world.—Continued

[Symbol size (small, large) corresponds to size of symbols shown in figure M5; deposit grade and tonnage are shown graphically in figure M6. Symbol size: S, small; L, large. WGS 84, World Geodetic System of 1984; negative values for latitude indicate that the deposit is in the Southern Hemisphere; negative values for longitude indicate that the deposit is in the Western Hemisphere. $\mathrm{Nb}_{2} \mathrm{O}_{5}$, niobium pentoxide; $\mathrm{Ta}_{2} \mathrm{O}_{5}$, tantalum pentoxide. Resource categories: M+In+If, measured+indicated+inferred; In+If, indicated+inferred. LCT, lithium-cesium-tantalum; Ma, mega-annum; NA, not available]

\begin{tabular}{|c|c|c|c|c|c|}
\hline Deposit & Country & Deposit type & $\begin{array}{l}\text { Symbol } \\
\text { size }\end{array}$ & Latitude & Longitude \\
\hline Sokli & Finland & Carbonatite & $\mathrm{S}$ & 67.77 & 29.23 \\
\hline Beauvoir-Echassieres & France & Rare-metal granite & $\mathrm{S}$ & 46.18 & 2.93 \\
\hline Ilimaussaq & Greenland & $\begin{array}{l}\text { Alkaline granite } \\
\text { and syenite }\end{array}$ & $\mathrm{S}$ & 61.01 & -45.71 \\
\hline Kanyika & Malawi & $\begin{array}{c}\text { Alkaline granite } \\
\text { and syenite }\end{array}$ & $\mathrm{S}$ & -12.63 & 33.63 \\
\hline Halzan-Buregtei & Mongolia & $\begin{array}{l}\text { Alkaline granite } \\
\text { and syenite }\end{array}$ & $\mathrm{S}$ & 48.42 & 91.97 \\
\hline Muiane & Mozambique & LCT pegmatite & $\mathrm{L}$ & -15.74 & 38.25 \\
\hline Mutala & Mozambique & LCT pegmatite & $\mathrm{L}$ & -15.92 & 37.92 \\
\hline Tantalite Valley & Namibia & LCT pegmatite & $\mathrm{L}$ & -28.72 & 18.80 \\
\hline Three Aloes & Namibia & LCT pegmatite & $\mathrm{L}$ & -21.22 & 14.87 \\
\hline $\begin{array}{r}\text { Central Nigerian } \\
\text { pegmatite belt }\end{array}$ & Nigeria & LCT pegmatite & $\mathrm{S}$ & 8.00 & 6.00 \\
\hline Jos Plateau & Nigeria & $\begin{array}{c}\text { Alkaline granite } \\
\text { and syenite }\end{array}$ & $\mathrm{L}$ & 9.17 & 9.75 \\
\hline Alakhinskoye & Russia & Rare-metal granite & $\mathrm{S}$ & 49.44 & 86.96 \\
\hline Lovozero & Russia & $\begin{array}{l}\text { Alkaline granite/ } \\
\text { syentite }\end{array}$ & $\mathrm{L}$ & 67.89 & 34.61 \\
\hline Ghurayyah & Saudi Arabia & $\begin{array}{c}\text { Alkaline granite } \\
\text { and syenite }\end{array}$ & S & 27.92 & 35.80 \\
\hline Pilanesberg & South Africa & $\begin{array}{c}\text { Alkaline granite } \\
\text { and syenite }\end{array}$ & $\mathrm{S}$ & -24.23 & 27.07 \\
\hline Kougarok & United States & Rare-metal granite & S & 65.71 & -165.23 \\
\hline Elk Creek & United States & Carbonatite & S & 40.27 & -96.19 \\
\hline Iron Hill (Powderhorn) & United States & Carbonatite & S & 38.23 & -106.71 \\
\hline Eagle & Zimbabwe & LCT pegmatite & $\mathrm{L}$ & -18.50 & 32.43 \\
\hline Donsa & Zimbabwe & LCT pegmatite & $\mathrm{L}$ & -18.50 & 32.43 \\
\hline
\end{tabular}


Table M4. Location, grade, tonnage, and other data for selected niobium-tantalum deposits of the world.-Continued

[Symbol size (small, large) corresponds to size of symbols shown in figure M5; deposit grade and tonnage are shown graphically in figure M6. Symbol size: S, small; L, large. WGS 84, World Geodetic System of 1984; negative values for latitude indicate that the deposit is in the Southern Hemisphere; negative values for longitude indicate that the deposit is in the Western Hemisphere. $\mathrm{Nb}_{2} \mathrm{O}_{5}$, niobium pentoxide; $\mathrm{Ta}_{2} \mathrm{O}_{5}$, tantalum pentoxide. Resource categories: M+In+If, measured+indicated+inferred; In+If, indicated+inferred. LCT, lithium-cesium-tantalum; Ma, mega-annum; NA, not available]

\begin{tabular}{|c|c|c|c|c|c|c|}
\hline Age & $\begin{array}{c}\text { Resource } \\
\text { (million } \\
\text { metric tons) }\end{array}$ & $\begin{array}{c}\text { Grade } \\
\left(\% \mathrm{Nb}_{2} \mathrm{O}_{5}\right)\end{array}$ & $\begin{array}{c}\text { Grade } \\
\left(\% \mathrm{Ta}_{2} \mathrm{O}_{5}\right)\end{array}$ & $\begin{array}{l}\text { Resource } \\
\text { categories }\end{array}$ & Reference(s) & Deposit \\
\hline NA & 110 & $?$ & NA & Hard rock ore & Siirama, 2009 & Sokli \\
\hline $308 \pm 2 \mathrm{Ma}$ & 0.02 & NA & 0.012 & NA & Raimbault and others, 1985 & Beauvoir-Echassieres \\
\hline NA & 54 & 0.11 & 0.04 & Resources & $\begin{array}{c}\text { Salvi and Williams-Jones, } \\
\text { 2005; Fetherston, } 2004\end{array}$ & Ilimaussaq \\
\hline NA & 60 & 0.29 & 0.014 & $M+I n+I f$ & Papp, 2013a & Kanyika \\
\hline NA & NA & NA & NA & NA & Fetherston, 2004 & Halzan-Buregtei \\
\hline NA & 1.375 & NA & 0.025 & $M+I n+I f$ & $\begin{array}{l}\text { Global Mining Services } \\
\text { Pty. Ltd., 2009, p. } 57\end{array}$ & Muiane \\
\hline NA & NA & NA & NA & NA & Papp, 2013a & Mutala \\
\hline NA & 0.74 & NA & 0.043 & NA & Fetherston, 2004 & Tantalite Valley \\
\hline NA & 7.2 & NA & 0.05 & NA & Fetherston, 2004 & Three Aloes \\
\hline 535 to $555 \mathrm{Ma}$ & NA & NA & NA & NA & $\begin{array}{l}\text { Matheis, 1987; Melcher } \\
\text { and others, } 2015\end{array}$ & $\begin{array}{r}\text { Central Nigerian } \\
\text { pegmatite belt }\end{array}$ \\
\hline About $198 \mathrm{Ma}$ & NA & NA & NA & NA & Melcher and others, 2015 & Jos Plateau \\
\hline NA & 0.015 to 0.020 & NA & 0.013 to 0.017 & NA & Fetherston, 2004 & Alakhinskoye \\
\hline NA & NA & NA & NA & NA & $\begin{array}{c}\text { Salvi and Williams-Jones, } \\
\text { 2005; Fetherston, } 2004\end{array}$ & Lovozero \\
\hline NA & 385 & 0.284 & 0.0245 & NA & Tertiary Minerals plc, 2013 & Ghurayyah \\
\hline NA & NA & NA & NA & NA & Lurie, 1986 & Pilanesberg \\
\hline NA & NA & NA & NA & NA & Fetherston, 2004 & Kougarok \\
\hline NA & 102.6 & 0.638 & NA & In+If & Daigle, 2012 & Elk Creek \\
\hline NA & 0.374 & 0.057 & NA & NA & Long and others, 2010 & $\begin{array}{l}\text { Iron Hill (Powder- } \\
\text { horn) }\end{array}$ \\
\hline NA & 0.61 & NA & 0.034 & NA & Fetherston, 2004 & Eagle \\
\hline NA & 1.62 & NA & 0.025 & NA & Fetherston, 2004 & Donsa \\
\hline
\end{tabular}




\section{Carbonatites and Associated Rocks}

Carbonatites are igneous rocks that are more than 50 percent composed of primary carbonate minerals, by volume, mainly calcite $\left(\mathrm{CaCO}_{3}\right)$, dolomite $\left(\mathrm{CaMg}\left(\mathrm{CO}_{3}\right)_{2}\right)$, and ankerite $\left(\mathrm{Ca}\left(\mathrm{Mg}, \mathrm{Fe}^{2+}, \mathrm{Mn}\right)\left(\mathrm{CO}_{3}\right)_{2}\right)$. Associated minerals commonly include alkali-rich (sodium or potassium) pyroxenes and amphiboles, phlogopite (magnesium-rich mica), magnetite, apatite (calcium phosphate), and olivine (iron-magnesium silicate). In addition, a large number of rare or exotic minerals may be present. Most carbonatites occur as relatively small (up to a few tens of square kilometers) intrusions, such as dikes, sills, and small plug- or crescentshaped bodies (fig. M7A); more rarely, they can occur as larger intrusions (plutons) or as volcanic deposits (lava flows and fragmental rocks). In three dimensions, carbonatite intrusions typically form vertical pipe-like bodies (fig. M7B). Carbonatites are commonly spatially associated with alkaline silicate rocks characterized by a wide range of sodium- or potassium-rich minerals and little or no quartz (Barker, 1989).
Many carbonatites are surrounded by an aureole of chemically altered country rocks (fenites) produced by the reaction of nearby rocks with hot sodium- and (or) potassium-rich fluids derived from the carbonatite (fig. M7).

A recent compilation by Woolley and Kjarsgaard (2008) lists 527 carbonatites worldwide. Most carbonatites (88 percent of all dated carbonatites) are located in cratons (the oldest, stable portions of continents) and were emplaced during periods of continental extension or rifting. In many carbonatite-bearing provinces, there have been repeated episodes of carbonatite emplacement, with as many as five episodes separated by hundreds of millions of years and extending from the late Archean to the present. Sixty-four percent of dated carbonatites are Paleozoic in age, however (Woolley and Bailey, 2012). Their source magmas are thought to be derived directly from the mantle by relatively small degrees of partial melting and emplaced along major faults or crustal boundaries reopened in response to major changes in global plate-tectonic movements (Woolley and Bailey, 2012).

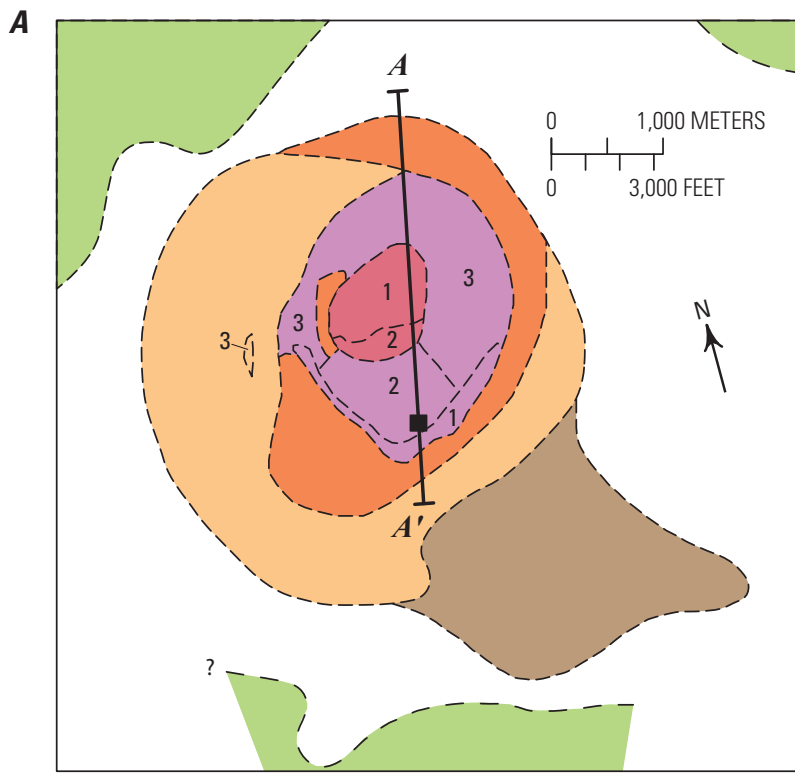

\section{EXPLANATION}

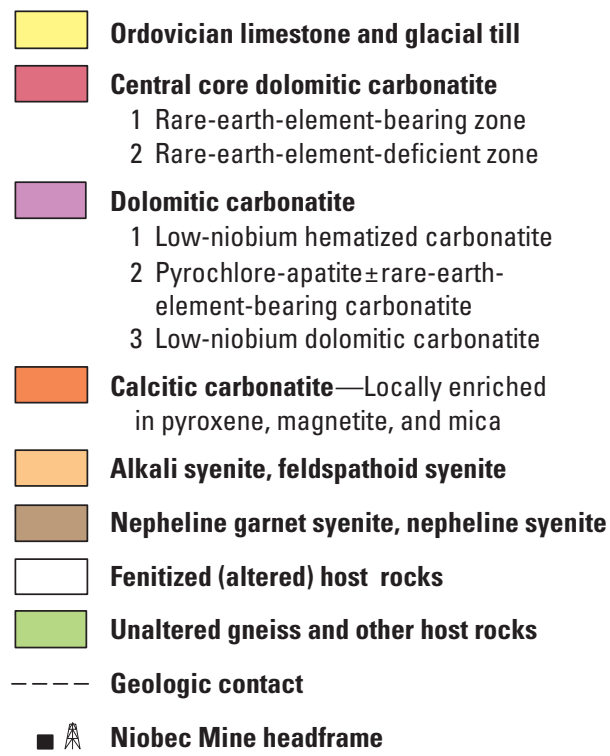

$B$

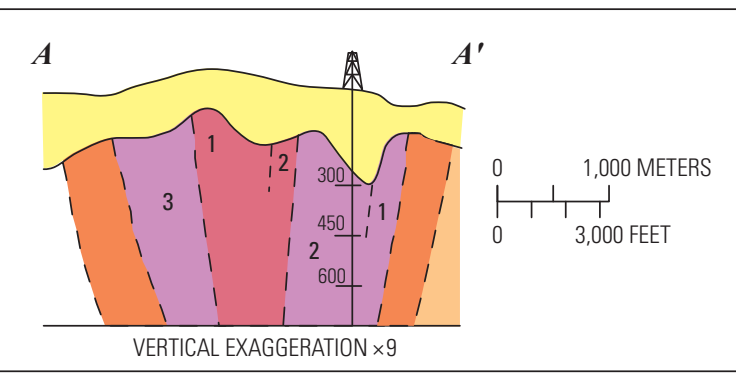

Niobec Mine headframe

Figure M7. Diagrams showing $A$, the subsurface geology of the Saint-Honoré carbonatite complex in southern Quebec, Canada, and $B$, a schematic north-south cross-section along line $A-A^{\prime}$ in $A$. The location of the Niobec underground mine is also shown. Modified from Richardson and Birkett (1996). 
Carbonatites are typically enriched in barium, fluorine, niobium, phosphorus, REEs, strontium, thorium, uranium, and zirconium. Not all carbonatites show similar enrichments in all elements, however; those related to carbohydrothermal fluids (hot fluids rich in carbon dioxide and water \pm fluorine) typically have enriched REEs and strontium, but not niobium, whereas carbonatites associated with alkaline igneous rocks are typically enriched in niobium, phosphorus, and titanium, but not REEs (Mitchell, 2005). The most common niobiumbearing minerals in carbonatites include members of the pyrochlore and perovskite mineral groups, as well as niobiumrich silicates, such as titanite. The diversity of mineral types in carbonate-hosted deposits, their diverse compositions, and textural evidence for replacement and resorption of mineral phases suggest that the niobium-bearing minerals represent transported and (or) mixed mineral assemblages and are not in situ products of crystallization (Mitchell, 2005). Along with serving as the major source of niobium, carbonatites can also host deposits of barite, copper, fluorite, magnetite, phosphate, REEs, titanium, and vermiculite (Mariano, 1989).

Brazil is the world's leading supplier of niobium (about 90 percent); its major deposits occur in Late Cretaceous carbonatite complexes. These complexes were emplaced along deep-seated faults located along the southwestern border of the ancient (Archean) São Francisco craton (Cordeiro and others, 2011). The Araxá deposit is the largest operating deposit; it has more than 460 million metric tons of weathered ore with a mean grade of 2.48 percent $\mathrm{Nb}_{2} \mathrm{O}_{5}$ (fig. M5; Cordeiro and others, 2011). The Barreiro carbonatite complex that hosts the Araxá deposit is approximately circular in shape with a diameter of about 4.5 kilometers $(\mathrm{km})$; it is composed of carbonatite, glimmerite (altered ultramafic rock composed almost entirely of biotite or phlogopite), and phoscorite (a rock composed of magnetite, apatite, and one of the silicate minerals clinopyroxene, olivine, or phylogopite) (Nasraoui and Waerenborgh, 2001). The complex is surrounded by a $2.5-\mathrm{km}-$ wide aureole of metasomatized (fluid-altered), alkali-enriched quartzite and mica schist country rocks. Phoscorite, which forms thick masses in dolomitic carbonatite in the central part of the complex, shows the highest concentrations of pyrochlore, the main niobium-bearing ore mineral, either as individual grains or in veins associated with magnetite. Intensive tropical weathering over the central part of the carbonatite complex has produced a lateritic cover up to 230 meters (m) thick that is enriched in pyrochlore and comprises the residual ore at Araxá (Nasraoui and Waerenborgh, 2001). The lateritic residual ore is exploited by open pit mining.

At Catalão, Brazil, niobium deposits are associated with two alkaline-carbonatite complexes, Catalão I and Catalão II (Cordeiro and others, 2011). The Catalão I complex consists of a vertical pipe-like, zoned intrusion about 6 $\mathrm{km}$ in diameter at the surface. Two pipe-like orebodies, the Mine II and the East Area, have been defined (Cordeiro and others, 2011). The Mine II orebody is hosted mainly by dolomitic carbonatite, and the East Area orebody is hosted by glimmerite. Both orebodies have been confirmed by drilling to extend to at least $800 \mathrm{~m}$ depth. The main niobium-bearing mineral in both deposits is pyrochlore, which in the East Area deposit is concentrated in late-stage dikes composed of nelsonite (magnetite-apatite-phlogopite rock). As at Araxá, current mining at Catalão II is in the weathered lateritic zone above the center of the complex.

The leading producer of niobium outside of Brazil is the Niobec Mine in Quebec, Canada. This mine is the only operating underground niobium mine in the world. The Niobec Mine is hosted by the Saint-Honoré carbonatite complex dated at 650 mega-annum (Ma) (Belzile, 2009), which is covered by Paleozoic limestone and glacial deposits. The ellipsoidal Saint-Honoré carbonatite complex is zoned with an outer ring of feldspathic (feldspar-bearing) and feldspathoidal (minerals that resemble feldspar but have a different structure and much lower silica content) alkaline rocks and an inner zone consisting of a series of carbonatite lenses (fig. M7). Like the Brazilian deposits, pyrochlore is the main niobium-bearing mineral, but it is very fine-grained ( 0.2 to 0.8 millimeters) and rarely visible. Although disseminated throughout the carbonatite, pyrochlore is especially concentrated in steeply dipping ( $>70$ degrees) mineralized lenses that are rich in, in order of abundance, magnetite, apatite, and biotite (Belzile, 2009). Some lenses extend to a vertical depth of at least $730 \mathrm{~m}$ and have average grades of between 0.44 and 0.51 percent $\mathrm{Nb}_{2} \mathrm{O}_{5}$. Other carbonatite complexes in Canada, including the nearby Crevier syenitecarbonatite complex, the Oka carbonatite complex to the south, and the Blue River complex in British Columbia, are currently being evaluated for their niobium resources.

Other carbonatite complexes around the world are known to host niobium mineralization, but none are currently in production. Two complexes are claimed to contain particularly large resources. The Tomtor complex in northern Siberia, Russia, is claimed to contain more niobium than the Araxá complex in Brazil along with significant REE resources (Kravchenko and Pokrovsky, 1995); grade and tonnage figures for the deposit are not publicly available. Although the central carbonatite in the Tomtor complex is reported to be mineralized, the higher grade niobium ( $>12$ percent niobium) and REE-rich ore is in weathered carbonatite and in a buried placer deposit interpreted to have formed in an ancient lake overlying the complex (Kravchenko and Pokrovsky, 1995).

The Morro dos Seis Lagos carbonatite in northwestern Brazil is poorly known but is reported to contain the world's largest single niobium deposit; its resources are said to be 2,900 million metric tons grading 2.85 percent $\mathrm{Nb}_{2} \mathrm{O}_{5}$ (Pollard, 1995).

Woolley and Kjarsgaard (2008) report 23 carbonatites in the United States. Of these, the Elk Creek carbonatite, which is located in the subsurface of Nebraska, is currently being evaluated. The inferred resources at the deposit are reported to be 102.6 million metric tons grading 0.638 percent $\mathrm{Nb}_{2} \mathrm{O}_{5}$ (Daigle, 2012). 


\section{Alkaline to Peralkaline Granites and Syenites}

The term "alkaline" encompasses a large variety of igneous rocks containing certain sodium- or potassium-rich minerals, such as feldspathoids and (or) alkali-rich pyroxenes and amphiboles and generally little or no quartz (Sørensen, 1974). Peralkaline rocks are a subset of alkaline rocks and are characterized by having a molecular amount of $\mathrm{Na}_{2} \mathrm{O}+\mathrm{K}_{2} \mathrm{O}$ that exceeds $\mathrm{Al}_{2} \mathrm{O}_{3}$ (termed the agpaitic index $>1$ ). Alkaline rocks can range from ultramafic to felsic and from silicaundersaturated (feldspathoid-bearing) to silica-oversaturated (quartz-bearing). They are most commonly found in intraplate settings, such as continental rift zones (for example, the East African rift zone) and oceanic islands (for example, the Azores, Hawaii, and Réunion), but they can also be found in some orogenic belts where they were emplaced after major tectonic deformation. An important feature of alkaline rocks, but particularly peralkaline rocks, is unusual and locally extreme enrichment in alkalis; HFSEs, including zirconium, niobium, titanium, uranium, yttrium, and REEs; and halogens, such as fluorine and chlorine (Salvi and Williams-Jones, 2005). As a result, alkaline igneous rocks can contain mineral deposits with high contents of HFSEs, including niobium, but they less commonly have high contents of tantalum.

Alkaline magmas are the product of low degrees of partial melting in a deep, chemically undepleted mantle (Niu and O'Hara, 2003). As a result, alkaline magmas are enriched over many other magma types in incompatible elements, including the HFSEs. These incompatible elements become further enriched as the alkaline magmas cool and crystallize, becoming concentrated in the most evolved, volatile-rich granitic and syenitic (same general composition as granite but with potassium feldspar dominant and little or no quartz $[<5$ percent $]$ ) melts and eventually forming disseminated ore minerals in the crystallized rocks. In addition, because the HFSEs form relatively dense minerals, they can accumulate into layers through crystal settling and be transported and mixed by currents or new injections of magma (Mitchell, 2005). Many alkaline igneous complexes also show extensive evidence of hydrothermal alteration, commonly with the most altered rocks also having the highest HFSE and REE contents. Although the role of fluids in the transport of HFSEs and REEs is still a matter of debate, growing evidence suggests that these elements are mobile in fluids that are enriched in fluorine, chlorine, and (or) carbon dioxide $\left(\mathrm{CO}_{2}\right)$ (Salvi and WilliamsJones, 2005). Typical ore minerals in mineralized peralkaline granites are usually niobium-rich pyrochlore and columbite.

Alkaline intrusive complexes are not currently major sources of niobium and tantalum production, although exploration is ongoing in some areas (for example, Strange Lake in Canada and Ghurayyah in Saudi Arabia). Examples of alkaline igneous complexes include the Pitinga complex in Brazil, the Strange Lake and Thor Lake complexes in Canada, the Ilímaussaq and Motzfeldt complexes in southern Greenland, the very large Lovozero complex in Russia, and the Pilanesberg complex in South Africa (fig. M5). Alkaline intrusive complexes have been identified in the United States, including Bokan Mountain in Alaska and Magnet Cove in Arkansas, but they are not known to contain significant niobium and tantalum resources of current economic interest.

The Devonian Lovozero alkaline complex on the Kola Peninsula of Russia and the adjacent Khibina complex together make up the largest peralkaline igneous intrusions in the world, covering an area of about 2,000 square kilometers $\left(\mathrm{km}^{2}\right)$. The Khibina complex is host to one of the largest phosphate resources in the world ( 2.7 billion metric tons averaging 17.5 percent phosphorus pentoxide $\left[\mathrm{P}_{2} \mathrm{O}_{5}\right]$ ), whereas the Lovozero complex hosts zirconium, niobium, REEs, yttrium, strontium, barium, and phosphorus, which occur as eudialyte (a zirconium-bearing silicate mineral), loparite, and apatite (Salvi and Williams-Jones, 2005). The Lovozero complex, which is exposed over an area of $650 \mathrm{~km}^{2}$, occurs as a trough-shaped intrusion composed of three main intrusive phases (fig. M8) (Kogarko and others, 2010). The oldest phase (phase 1), which accounts for about 5 percent of the total volume, consists of nepheline syenites with varied mineralogy, but it contains no loparite or eudialyte. The next phase, (phase II), which accounts for about 77 percent of the total volume, consists of layered nepheline syenites with varied mineralogy and locally accessory loparite or eudialyte. Loparite is concentrated up to 25 percent, by volume, in some layers (Kogarko and others, 2002). Loparite concentrate has been produced intermittently during the past 50 years; about 30,000 metric tons grading 8 percent $\mathrm{Nb}_{2} \mathrm{O}_{5}$ and 0.7 percent $\mathrm{Ta}_{2} \mathrm{O}_{5}$ has reportedly been produced annually (Semenov, 1997). The third intrusive phase (phase III), which is also known as the eudialyte complex, accounts for about 18 percent of the total volume and consists of nepheline syenites that, particularly in the upper part of the complex, can contain seams and lenses of almost monomineralic eudialyte (50 to 85 percent) (Kogarko and others, 2010).

The Mesoproterozoic Ilímaussaq alkaline complex in southwestern Greenland is one of the most studied alkaline complexes in the world (Sørensen, 2001). It is 1 of 10 alkaline intrusions in the Gardar igneous province, which is a failed continental rift that was active between 1,350 and 1,140 Ma (Upton and others, 2003). The Ilímaussaq alkaline complex is the type locality for the rock-type peralkaline nepheline syenite and also 27 minerals. It contains large concentrations of a number of rare elements, including beryllium, lithium, niobium, REEs, uranium and thorium, yttrium, and zirconium, contained in about 220 different minerals, of which 9 are unique to this complex (Sørensen, 2001). The complex covers $136 \mathrm{~km}^{2}$ and has an exposed vertical thickness of 1,700 m; its total depth is not known. The main rare-metal deposits with potentially exploitable niobium, REEs, yttrium, and zirconium are present in 29 separate eudialyte-rich layers interpreted to have formed by crystal settling (Sørensen, 2001). Cumulatively, these rocks are estimated to contain a resource of about 54 million metric tons grading 1.1 percent zirconium dioxide $\left(\mathrm{ZrO}_{2}\right), 0.09$ percent yttrium oxide $\left(\mathrm{Y}_{2} \mathrm{O}_{3}\right)$, 0.56 percent rare-earth oxides, and 0.11 percent $\mathrm{Nb}_{2} \mathrm{O}_{5}$ 


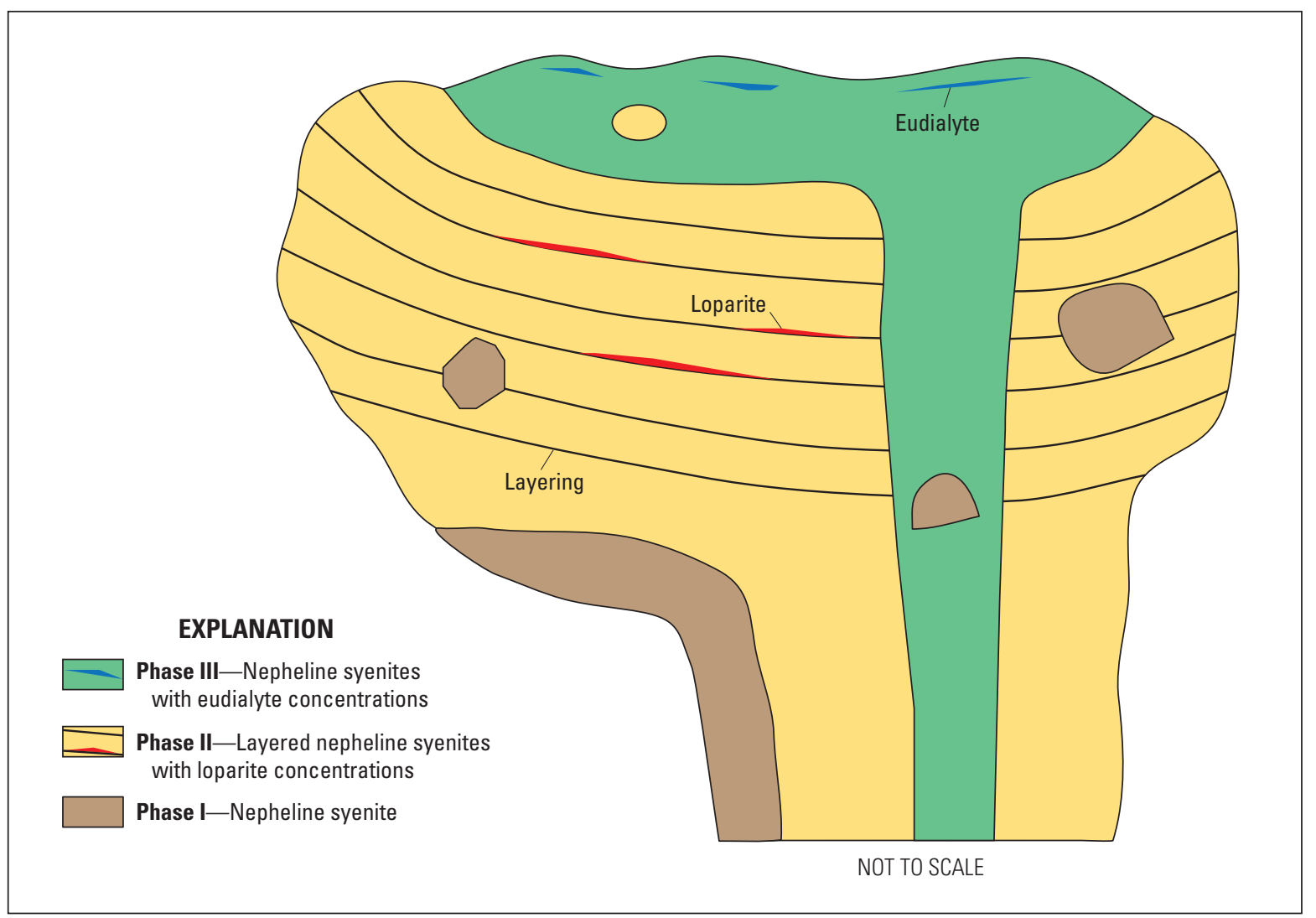

Figure M8. Schematic cross-section of the Lovozero alkaline intrusion, Kola Peninsula, Russia, showing the relation among the three intrusive phases and the niobium mineralization contained in eudialyte and loparite. After Kogarko and others (2002).

(Steenfelt, 1991). The Motzfeldt intrusion, which is another of the alkaline intrusions in the Gardar igneous province, has zones of hydrothermally altered syenite containing niobiumtantalum-REE-bearing pyrochlore mineralization (Steenfelt, 1991), which is the focus of ongoing exploration.

\section{Rare-Metal Granites and Lithium-Cesium- Tantalum-Type Pegmatites}

All economically important tantalum mineralization is related to rare-metal granites (also called rare-element granites) and lithium-cesium-tantalum (LCT)-type pegmatites. The rare-metal granites are generally peraluminous (have molecular $\left.\mathrm{Al}_{2} \mathrm{O}_{3}>\left[\mathrm{CaO}+\mathrm{Na}_{2} \mathrm{O}+\mathrm{K}_{2} \mathrm{O}\right]\right)$, muscovite- and albiterich granites that display high degrees of chemical fractionation, and represent the last stages of felsic magma evolution in upwardly differentiated granitic intrusions (Linnen and Cuney, 2005). The parental magmas are formed by partial melting of preexisting crustal rocks, particularly aluminous sediments, and are generally emplaced at shallow levels of the crust (in the upper few kilometers) during the late stages of or after major tectonic deformation and regional metamorphism in orogenic belts. They may show pervasive hydrothermal alteration and host disseminated tantalum and niobium mineralization, as well as tin and tungsten, in complex vein systems (stockworks) that developed from circulation of late-stage hydrothermal fluids. Typical mineralization consists of microlite, columbite-tantalite, tantalum-rich cassiterite (tin oxide), and lepidolite (lithium-rich mica).

LCT-type pegmatites are generally small (meters rather than kilometers in length and width) granitic intrusions characterized by extremely coarse but variable grain-size and enrichments in lithium, rubidium, cesium, beryllium, tantalum, and niobium ( $\mathrm{Ta}>\mathrm{Nb}$ ) (Černý and Ercit, 2005). They are the products of highly fractionated and volatile-rich granitic magmas generally derived from rare-metal granites. They commonly occur in aureoles surrounding the roof of their parental granite intrusion, and the mineralized and most fractionated pegmatites are found the farthest away (fig. M9). Most LCT-type pegmatites are concentrically but irregularly zoned (fig. M10), and typically have a thin border zone, a wall zone, an intermediate zone, an albite zone, and a core zone (Cameron and others, 1949; Fetherston, 2004). Tantalum mineralization is mostly concentrated in the intermediate and albite zones and generally consists of columbite-tantalite, ixiolite, microlite, and (or) wodginite. Additional mineralization may be present, including beryllium (as beryl, a beryllium aluminum silicate), cesium (as pollucite, a cesium 


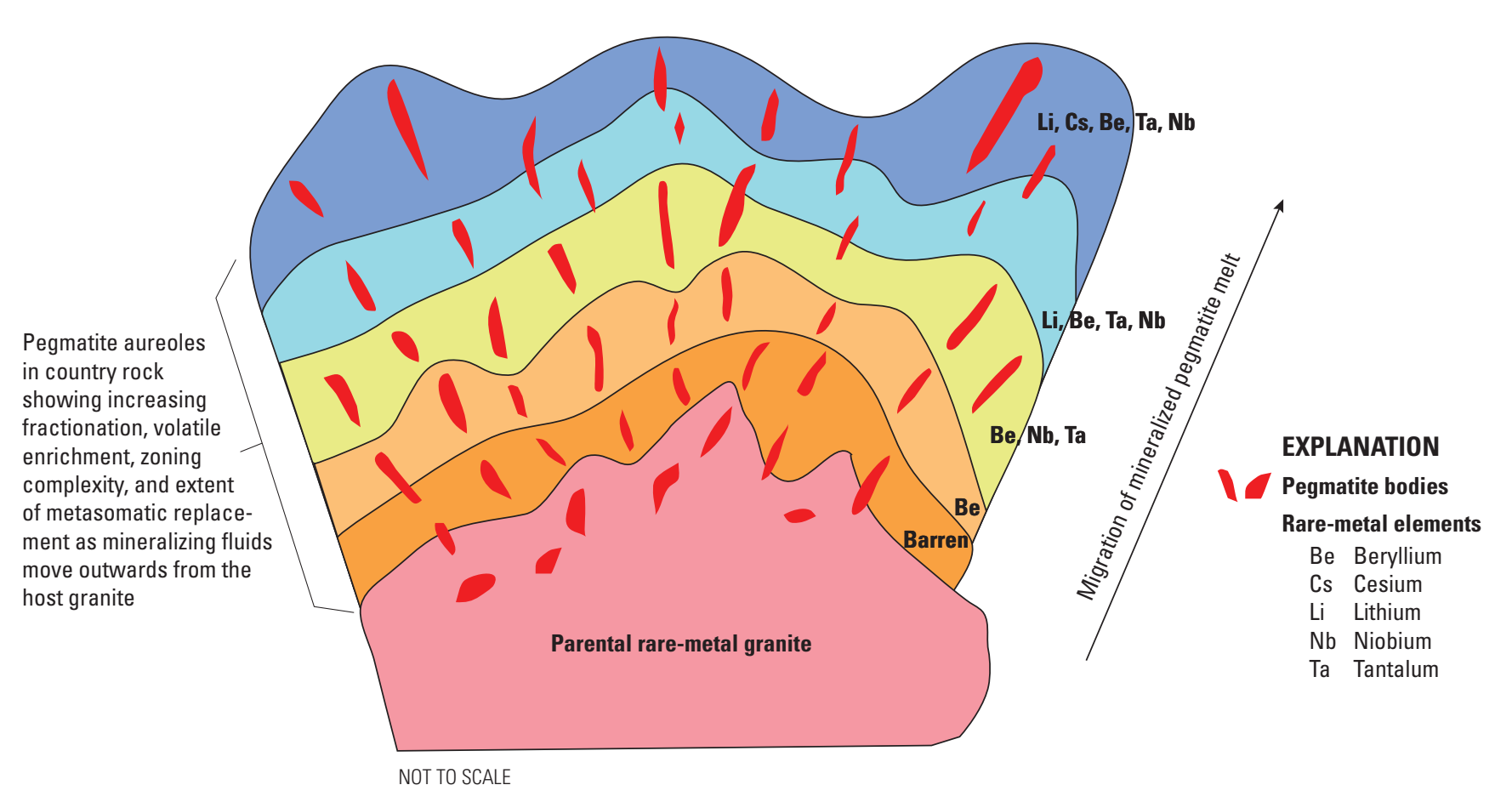

Figure M9. Schematic representation of regional lithium-cesium-tantalum (LCT) rare-metal-bearing pegmatite zoning above a parental granite. After Černý (1991b).

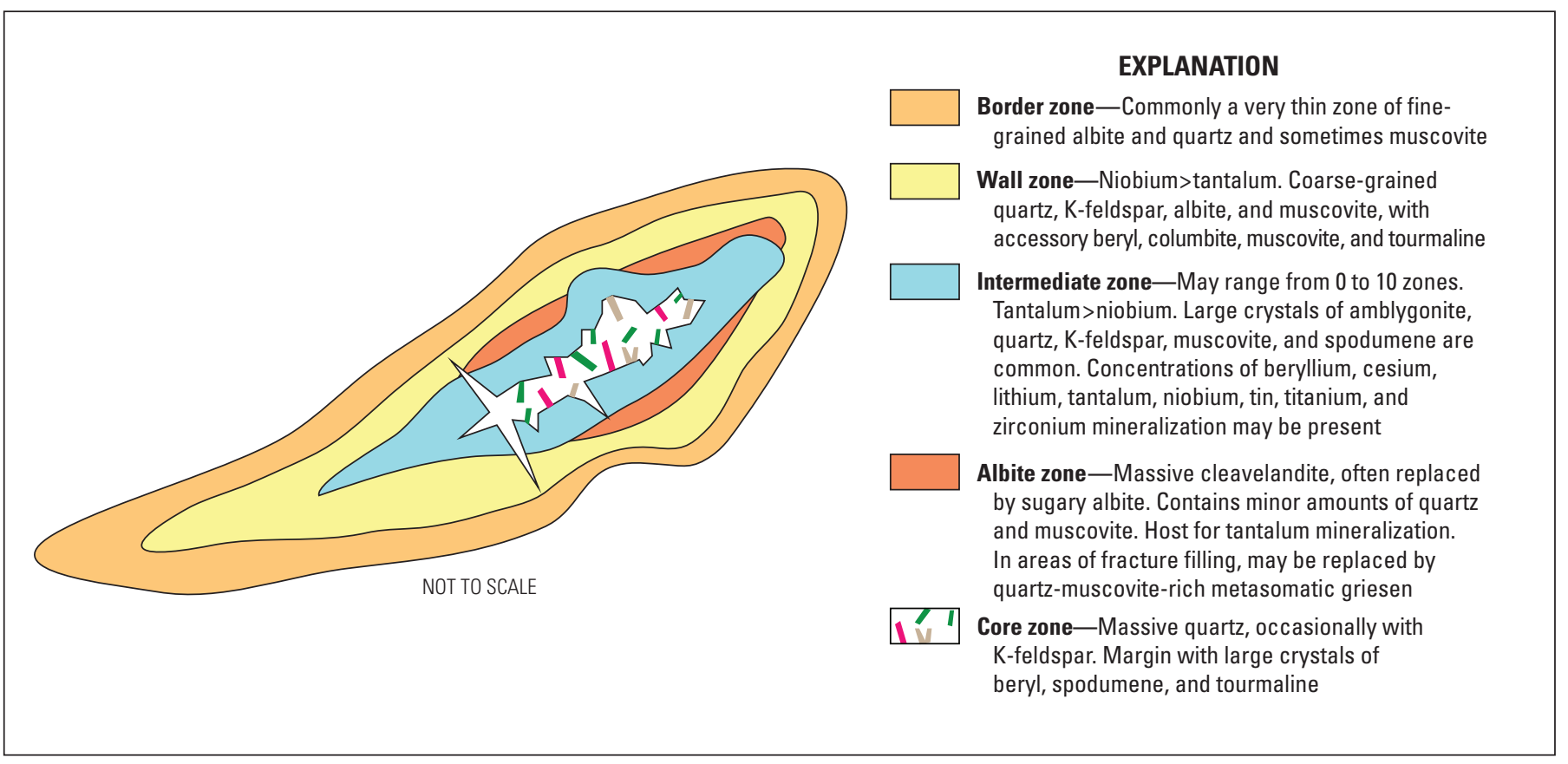

Figure M10. Schematic cross-section of a concentrically zoned lithium-cesium-tantalum (LCT) rare-metal-bearing pegmatite. After Černý (1991a) and Fetherston (2004). 
zeolite), lithium (as spodumene, a lithium pyroxene; petalite, a lithium aluminum silicate; and lepidolite), tin (as cassiterite, a tin oxide), and a number of gemstones. LCT-type pegmatites are also mined for albite, muscovite, potassium feldspar, and ultrapure quartz. Like their parental rare-metal granites, LCT-type pegmatites are widely distributed globally (fig. M5), and range in age from Archean to Mesozoic, but they are found to be concentrated particularly during times of continental collision and supercontinent assembly (Bradley and McCauley, 2013). By far the largest LCT-pegmatite-hosted mineral deposits are of Archean age, however (for example, the Greenbushes and Wodgina deposits in Australia and the Tanco deposit in Canada).

In recent years, pegmatites in the State of Western Australia, Australia, have been major world suppliers of tantalum, particularly the Greenbushes and the Wodgina Mines. The giant ( $>3 \mathrm{~km}$ long) Greenbushes pegmatite is located $250 \mathrm{~km}$ south of Perth and has been mined for tin and tantalum since 1888, and more recently also for kaolin and lithium (Partington and others, 1995). It contains the world's largest identified pegmatite-hosted tantalum resource and mining operation. The pegmatite is late Archean in age and appears to have been intruded along a crustal fault zone synchronously with deformation. Unlike many other pegmatite districts, there is no evidence for a nearby parental granite pluton for the Greenbushes pegmatite. Four major compositional zones have been identified; however, the most compositionally evolved zones (that is, the most lithium-rich) occur at the top and bottom of the pegmatite rather than at the center. Early formed tantalum minerals are mainly wodginite and ixiolite; later tantalum minerals (tantalite and tapiolite) occur within fractures, whereas microlite is related to later hydrothermal mineralization (Partington and others, 1995). The main ore zones generally occur within the more tourmaline-rich portions of albite-rich zones in the pegmatite. Most ore produced at Greenbushes since 1888 has been by open pit mining of weathered pegmatite and alluvial sources; recently, however, underground mining of hard-rock ore has also begun.

The Wodgina pegmatite district is one of more than 27 pegmatite districts located in the northern part of Western Australia, Australia; it includes the Wodgina main lode and Mount Cassiterite tantalum-mineralized pegmatites (Sweetapple and Collins, 2002). The Wodgina main lode pegmatite is a north-south-trending, easterly dipping (20 to 50 degrees) dike with a total length of about $1 \mathrm{~km}$ and a thickness ranging from 5 to $40 \mathrm{~m}$; most mining has been in the northern, thicker end. Originally discovered in 1902, the Wodgina pegmatite has intermittently produced beryl, tantalum, and tin during the past 100 years. The main tantalum mineral is manganese-rich tantalite, which, together with some manganese-rich columbite and wodginite, is found mainly in marginal cleavelandite (a platy form of albite) (Sweetapple and Collins, 2002). In the Mount Cassiterite pegmatite, which lies just south of Wodgina, wodginite is the main tantalum mineral (Sweetapple and Collins, 2002). Tantalum from both pegmatites is recovered by open pit mining. Additional tantalum-bearing pegmatites occur in Western Australia, including the producing Mount Cattlin pegmatite, as well as the Bald Hill and the Mount Deans deposits, which are under development (Fetherston, 2004).

A number of pegmatite fields are present in Africa (fig. M5). Pegmatites in Ethiopia (Kenticha) and Mozambique (Marropino) were significant tantalum producers in the 2000-13 time period (Bleiwas and others, 2015); others were undergoing exploration or development for tantalum and associated resources (for example, the Morrua and the Mutala pegmatites in Mozambique). Mining of columbite-tantalite (also called coltan) from weathered pegmatites and from secondary placer deposits derived from pegmatites in central Africa, particularly in Burundi, the Democratic Republic of the Congo (Congo [Kinshasa]), Nigeria, Rwanda, and Uganda, has been conducted mainly by artisanal family mining groups and prospectors. The Main Kenticha pegmatite in Ethiopia is a Cambrian-age intrusion exposed across a length of more than $2 \mathrm{~km}$ (Küster, 2009). The pegmatite displays asymmetric internal textural and mineral zonation with manganese-rich tantalite as well as ixiolite concentrated in the upper intermediate and core zones. The deposit also contains valuable lithium resources, although these are not currently mined. Tantalum production has been from deeply weathered regolith over the pegmatite; however, exploration drilling of the hard-rock pegmatite is being conducted to evaluate the size of the primary mineralization (Küster, 2009). To the south of Kenticha, the Alto Ligonha pegmatite province in Mozambique contains numerous mineralized pegmatites, which have been mined intermittently since 1926. Tantalum concentrate was produced from ore from the Marropino Mine, concessions were held for the Morrua and Mutala deposits, and exploration was ongoing in adjacent areas. In Egypt, rare-metal granites were the focus of ongoing exploration and development activities, including the Abu Dabbab and Nuweibi granites (Küster, 2009). These deposits consist of fine-grained columbite-tantalite minerals disseminated throughout the granite intrusions. In addition, these intrusions host tin mineralization and ceramic-grade feldspar (Bleiwas and others, 2015).

In China, the Yichun tantalum-niobium-lithium deposit is the leading tantalum producer, accounting for more than one-half of China's tantalum output (Fetherston, 2004). The deposit is in a small, sheet-like rare-metal granite that represents the most fractionated and youngest phase of the Jurassic Yanshan granite intrusion (Yin and others, 1995). The main tantalum minerals in this deposit are columbite-tantalite and tantalum-rich cassiterite along with minor microlite. The 801 Mine, which is located in the eastern part of the Inner Mongolia Autonomous Region about $640 \mathrm{~km}$ northeast of Beijing, is reported to have large resources of niobium, REEs, tantalum, and zirconium (Fetherston, 2004). Additionally, pegmatites in the Altai region of northwestern China and in the Nanping region of southeastern China have also produced columbite-tantalite. 
In South America, the Volta Grande pegmatite mine located near the city of Nazareno in the State of Minas Gerais, Brazil, is a significant supplier of lithium, niobium, and tantalum. The main deposit is in a large, about $1-\mathrm{km}-$ long, subhorizontal, zoned albite-spodumene pegmatite body of Paleoproterozoic age (Lagache and Quéméneur, 1997). Cassiterite, microlite, and tantalite are the main tantalum-niobium-bearing minerals. A distinctive feature of pegmatites in the Volta Grande district is that they are exceptionally enriched in lithium and rubidium (Lagache and Quéméneur, 1997).

The only pegmatite mine in North America producing tantalum in the 2000-13 time period was the Tanco deposit at Bernic Lake in southeastern Manitoba, Canada (Bleiwas and others, 2015). Operated briefly as a tin mine beginning in 1929, tantalum production began only in 1969 . Full-scale mining to produce lithium from spodumene (the underground mine's major product), along with cesium, rubidium, and tantalum, began in 1984. Tanco is part of the rare-metal-bearing Bernic Lake pegmatite group, which intrudes metamorphosed Archean volcanic rocks. The Tanco pegmatite occurs as a shallowly dipping sheet that is up to about $100 \mathrm{~m}$ thick and can be traced for about 1,600 $\mathrm{m}$ along strike. The pegmatite consists of nine zones, each of which has a different mineralogy, texture, and location, as well as a halo of altered mafic host rock. The deposit has a very complex mineralogy_more than 80 minerals are present, including 14 tantalum-bearing minerals (Černý, 2005). Wodginite is the principal ore mineral, and it occurs mainly in a zone lying below the quartz core (Grice and others, 1972). Numerous other tantalum-bearing pegmatites have been identified in Ontario and Manitoba (Selway and others, 2005); several were undergoing evaluation of their tantalum and associated resources. In the United States, niobium-tantalum minerals, chiefly columbite, were recovered intermittently from a number of pegmatites in the past (Barton, 1962). The Harding pegmatite in New Mexico, which is a complexly zoned lithium- and beryllium-bearing pegmatite, was an important source of tantalum briefly during World War II and supplied about 3 metric tons of microlite concentrate (Parker and Adams, 1973). There has been no reported tantalum mine production in the United States since 1959.

\section{Resources and Production}

Data on global reserves and resources of niobium and tantalum are fragmentary and incomplete (Crockett and Sutphin, 1993). Identified resources of niobium and tantalum are large, however, and are estimated to be more than sufficient to meet global demand for possibly the next 500 years (British Geological Survey, 2011). The specificity and accuracy of worldwide data for measured, indicated, and inferred resources and (or) proven and probable reserves vary widely. In general, the most accurate data are available only for individual mines or deposits, particularly those in Australia, Brazil, and Canada. Even in these cases, however, it is uncertain how reliable the national resource estimate totals are. In addition, some world demand for tantalum, and to a lesser extent, niobium, is met by production of these elements as byproducts of tin mining and metallurgy. Accurately measuring and classifying niobium and tantalum resources within the tin sector is difficult and has not been attempted (Crockett and Sutphin, 1993).

\section{Niobium Reserves and Other Identified Resources}

The current identified resources of niobium are located predominantly in Brazil (about 95 percent) and Canada (about 3.5 percent) (fig. M11) (British Geological Survey, 2011; Papp, 2013b). Additional (though less well reported) resources are located in Angola, Australia, China, Greenland, Malawi, Russia, South Africa, and the United States. The largest niobium resources are hosted by carbonatite complexes in Brazil. Resources in alkaline granite or syenite complexes are widespread and can be large, but they are generally lower in grade than carbonatite-hosted deposits (fig. M6). In addition, these deposits tend to have more complex geology and

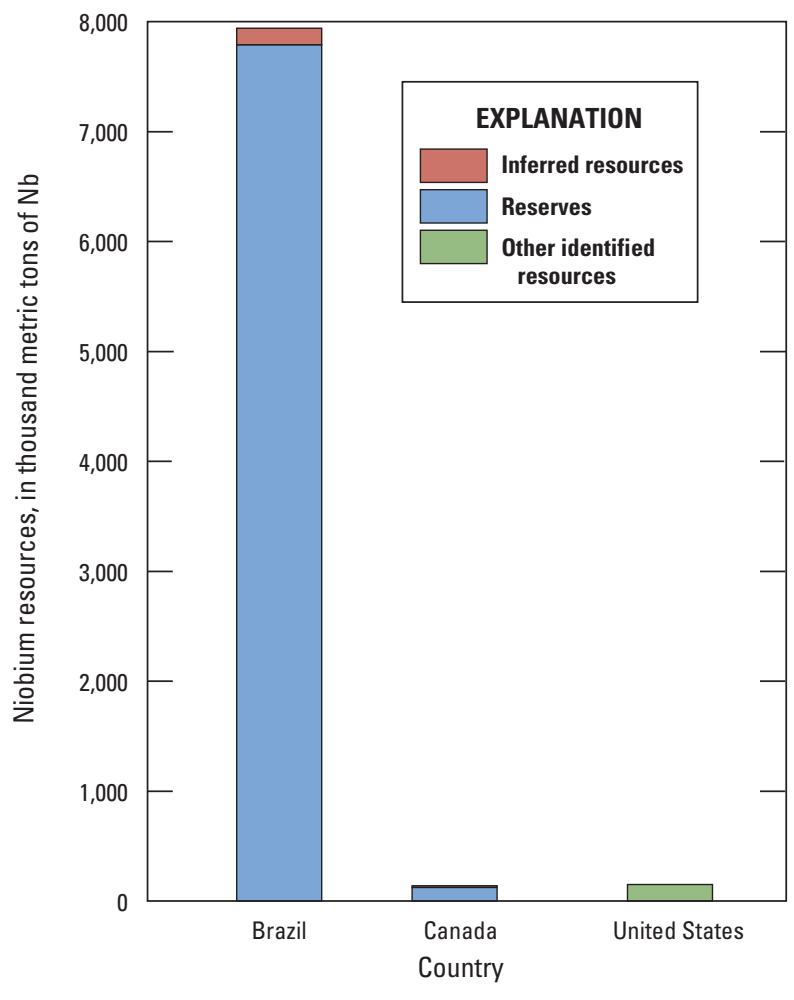

Figure M11. Bar chart showing niobium (Nb) resources and reserves in Brazil, Canada, and the United States, in thousand metric tons of $\mathrm{Nb}$ (British Geological Survey, 2011, p. 18). 
mineralogy than do carbonatites, which can affect the ease with which the niobium could be recovered.

The United States is estimated to have about 150,000 metric tons of niobium resources; these resources are associated primarily with carbonatites and alkaline intrusive complexes and, to a lesser extent, with pegmatites (Parker and Adams, 1973). The resources in the United States are all considered to be subeconomic at current niobium prices (Papp, 2013b).

\section{Tantalum Reserves and Other Identified Resources}

Tantalum resources are more widespread than those of niobium. Brazil has the largest share of global resourcesabout 106,000 metric tons of contained tantalum, which accounts for approximately 40 percent (fig. M12); the remaining 60 percent of identified tantalum resources occur in, in decreasing order of tonnage, Australia (about 54,000 metric tons), China and Southeast Asia (about 27,000 metric tons), Russia and the Middle East (about 26,000 metric tons), central Africa (about 23,000 metric tons), other Africa (about 17,500 metric tons), North America (about 4,500 metric tons), and Europe (about 1,900 metric tons). Tantalum resources in Brazil are principally associated with large pyrochlore deposits in carbonatite complexes and in the Volta Grande pegmatite district, whereas those in Australia are principally hosted by LCT-type pegmatites.

The United States has about 1,500 metric tons of identified tantalum resources, all of which are considered

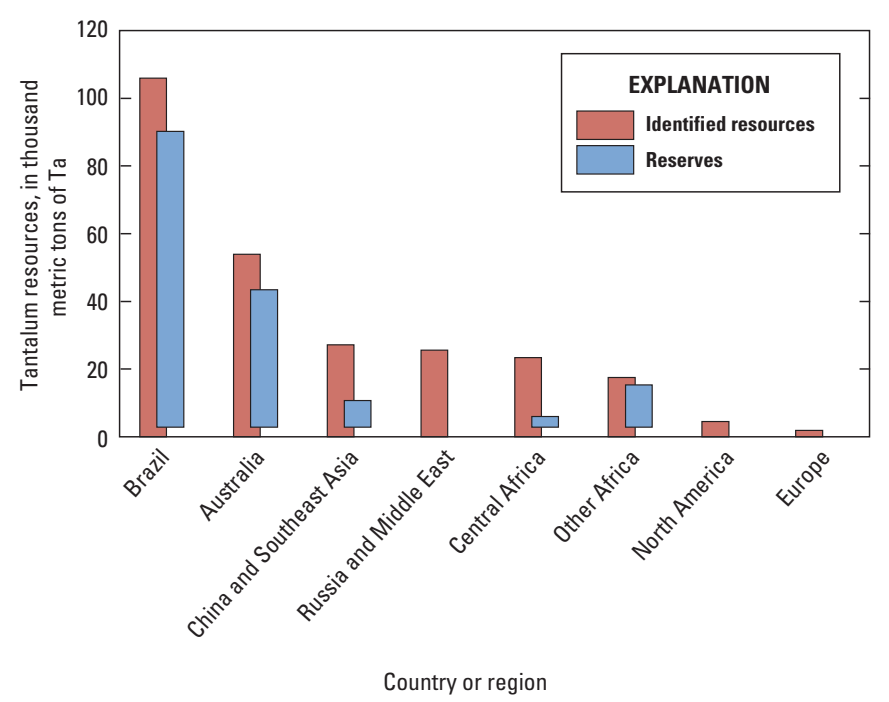

Figure M12. Bar chart showing global tantalum (Ta) resources and reserves, in thousand metric tons of Ta (British Geological Survey, 2011, p. 19). subeconomic (Papp, 2013c). These resources are primarily hosted in numerous LCT-type pegmatite districts around the country (Bradley and McCauley, 2013).

\section{Undiscovered Niobium and Tantalum Resources}

Additional niobium and tantalum resources are contained in undiscovered deposits around the world. Some of these are likely to occur in more remote or covered areas, potentially making for more challenging and expensive exploration and mining. Many of the 527 known carbonatite complexes worldwide (Woolley and Kjarsgaard, 2008) have not been fully explored and may contain undiscovered mineralization. These complexes are particularly abundant in southern Africa, parts of Asia, Brazil, Canada, and Russia (Woolley and Kjarsgaard, 2008). These same areas also commonly host alkaline granite and syenite complexes, many of which also remain to be more fully explored. A number of carbonatites and alkaline intrusions are currently undergoing exploration activity because of recent efforts to find new sources of REE resources (Long, 2011).

Most of the identified carbonatites in the United States are currently known to have only low grades of niobium (Berger and others, 2009). An exception may be the Elk Creek carbonatite in Nebraska, which has inferred niobium resources of 102.6 million metric tons grading 0.638 percent $\mathrm{Nb}_{2} \mathrm{O}_{5}$ (Daigle, 2012). Alkaline intrusions are widespread and occur in the Appalachian Mountains and the Ouachita Mountains, in west Texas, throughout the Rocky Mountain region, and in parts of Alaska (Barker, 1974). Additional alkaline granite-syenite intrusions have been identified in central Wisconsin and the Black Hills of South Dakota. Although most of these intrusions are not known to have significant niobium or tantalum mineralization, they have not all been fully explored. An exception is the Magnet Cove complex in southern Arkansas, which has a central carbonatite with niobium-rich perovskite but overall low grades (Morris, 1987). The Bokan Mountain alkaline granite intrusion in southern Alaska is being explored for REEs and uranium (Long and others, 2010). In addition, the Kougarok tin-bearing granite in the Seward Peninsula of Alaska is being evaluated for its tantalum resources. Archean rocks that could host giant LCT-type pegmatite deposits have limited occurrence in the United States, and are found mostly in northern Michigan, Minnesota, and Wyoming. Major pegmatite fields are not known in these areas, although exposures of rocks are limited in Michigan and Minnesota by glacial cover. Exploration of LCT-type pegmatites, such as those in the Appalachian Mountain and the Black Hills regions, have resulted in only subeconomic tantalum resources. 


\section{Niobium and Tantalum Production}

\section{Niobium}

World mine production of niobium rose steadily from approximately 25,000 metric tons of elemental niobium in 2000 to more than 60,000 metric tons of niobium in 2008 , and it has remained fairly steady since then (fig. M13A). The increase between 2000 and 2008 is largely linked to increased consumption of microalloyed steel, which is used in the manufacture of cars, buildings, ships, and refinery equipment. Increased demand for these steels reflects in large part industrial development in such countries as Brazil, China, and India in that time period. In addition, increased demand for mobile telephones, superconducting magnets, and other hightech devices has helped spur niobium production. Brazil and Canada have been the leading nations that produce niobium mineral concentrates, with Brazil by far the leading producer (fig. M14A). The leading companies that produced niobium ore and concentrates were Companhia Brasileira de Metalurgia e Mineração (CBMM) (Araxá Mine), Anglo American Brazil Ltd. (Catalão Mine), and Companhia Industrial Fluminense Mineração S.A. (Volta Grande Mine) in Brazil, and IAMGOLD Corp. (Niobec Mine) in Canada. Other countries, including Burundi, China (Yichun Mine), Ethiopia (Kenticha Mine), Nigeria, Russia (Lovozero Mine), Rwanda, and Uganda, also produced niobium mineral concentrates in 2011.

The leading niobium producers process the ore to make ferroniobium $(\mathrm{FeNb})$ or niobium pentoxide $\left(\mathrm{Nb}_{2} \mathrm{O}_{5}\right)$, which is then shipped to consumers. Other niobium mining operations ship niobium mineral concentrates to processing companies. The ore is crushed and ground, beneficiated by flotation and magnetic separation (to remove iron minerals) to produce a pyrochlore mineral concentrate grading 55 to 60 percent $\mathrm{Nb}_{2} \mathrm{O}_{5}$. Columbite and tin slags account for a minor amount of niobium production. Artisanal mining of columbite-tantalite (coltan) is carried out in central Africa, particularly in Burundi, Congo (Kinshasa), Nigeria, Rwanda, and Uganda.

\section{Tantalum}

Global tantalum mine production peaked in 2004 at just greater than 1,400 metric tons of elemental tantalum and mostly declined since 2006 to 770 metric tons in 2011 (fig. M13B). The decrease in tantalum production reflects the drop in tantalum prices that accompanied the global economic downturn and the increased volume of tantalum coming out of areas of armed conflict in Congo (Kinshasa). Australia and Brazil have been the leading national producers of tantalum mineral concentrates (fig. M14B), although since 2009, production from Australia has decreased, and production from Mozambique and some other countries has increased (Papp, 2013a). The leading companies producing tantalum mineral concentrates in 2011 were Companhia Industrial Fluminense Mineração S.A. (Volta Grande Mine) and Mineração Taboca S/A (Pitinga Mine) in Brazil and Noventa Ltd. (Marropino Mine) in Mozambique. The leading tantalum producer in other years was Global Advanced Metals from its Greenbushes and Wodgina Mines in Western Australia. Other countries, including Burundi, Canada (Tanco Mine), China (Yichun Mine), Congo (Kinshasa), Ethiopia (Kenticha Mine), Nigeria, Russia (Lovozero Mine), Rwanda, and Uganda also produced tantalum mineral concentrates in 2011.

About one-half of all tantalum production consists of tantalite ore, and the remainder comes from tin slag, from such other minerals as strüverite and columbite-tantalite, and from recycling and synthetic concentrates. Tin slag is produced primarily in Southeast Asia, Australia, and Brazil. Tantalum is mined from both open pit and underground operations. Heavy minerals that contain tantalum are separated from the bulk ore by gravity methods and flotation. The concentrate is then subject to electrical (electrostatic and [or] electromagnetic) separation and other methods used to separate tantalum minerals from other heavy minerals. Because most mining of tantalum recovers minerals that also contain niobium, a chemical processing step involving the addition of potassium fluoride is necessary to separate niobium from tantalum, resulting in compounds of $\mathrm{Nb}_{2} \mathrm{O}_{5}, \mathrm{Ta}_{2} \mathrm{O}_{5}$, potassium niobium fluoride $\left(\mathrm{K}_{2} \mathrm{Nb}_{2} \mathrm{~F}_{5}\right)$, and potassium tantalum fluoride $\left(\mathrm{K}_{2} \mathrm{Ta}_{2} \mathrm{~F}_{5}\right)$. The tantalum compounds are then smelted to make tantalum metal products (Roskill Information Services Ltd., 2012). The global supply of tantalum historically has been 70 percent from concentrates, 10 percent from tin slag, and 20 percent from recycling and synthetic concentrates (Schwela, 2010). Conventional mining accounted for 51 percent of the world's tantalum supply in 2011, artisanal mining accounted for 29 percent, and tin slags and synthetic concentrates accounted for 10 percent (Roskill Information Services Ltd., 2012). 

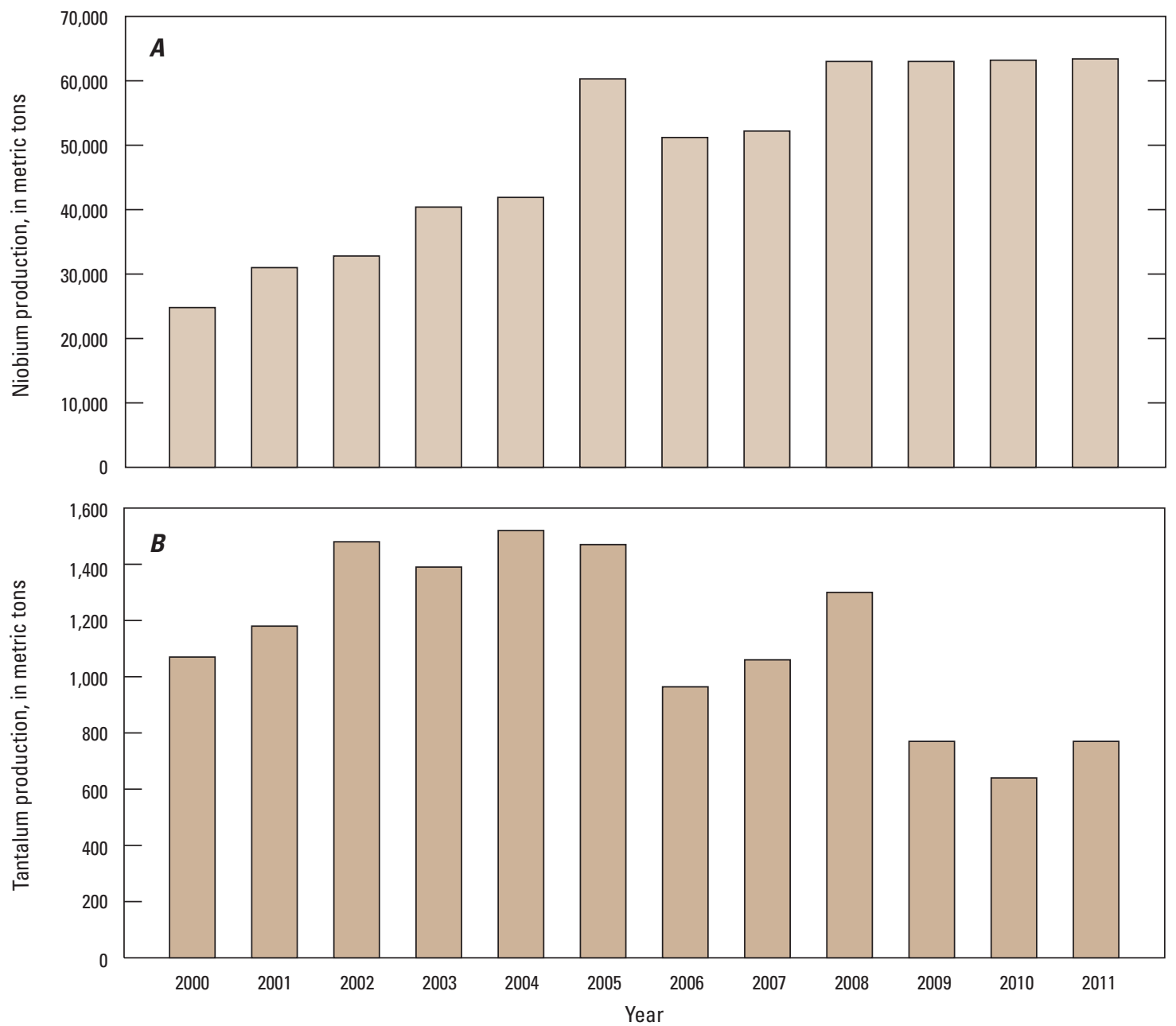

Figure M13. Bar charts showing global mine production of $A$, niobium, and $B$, tantalum, from 2000 to 2011, in metric tons of contained niobium and tantalum (Papp, 2013a).

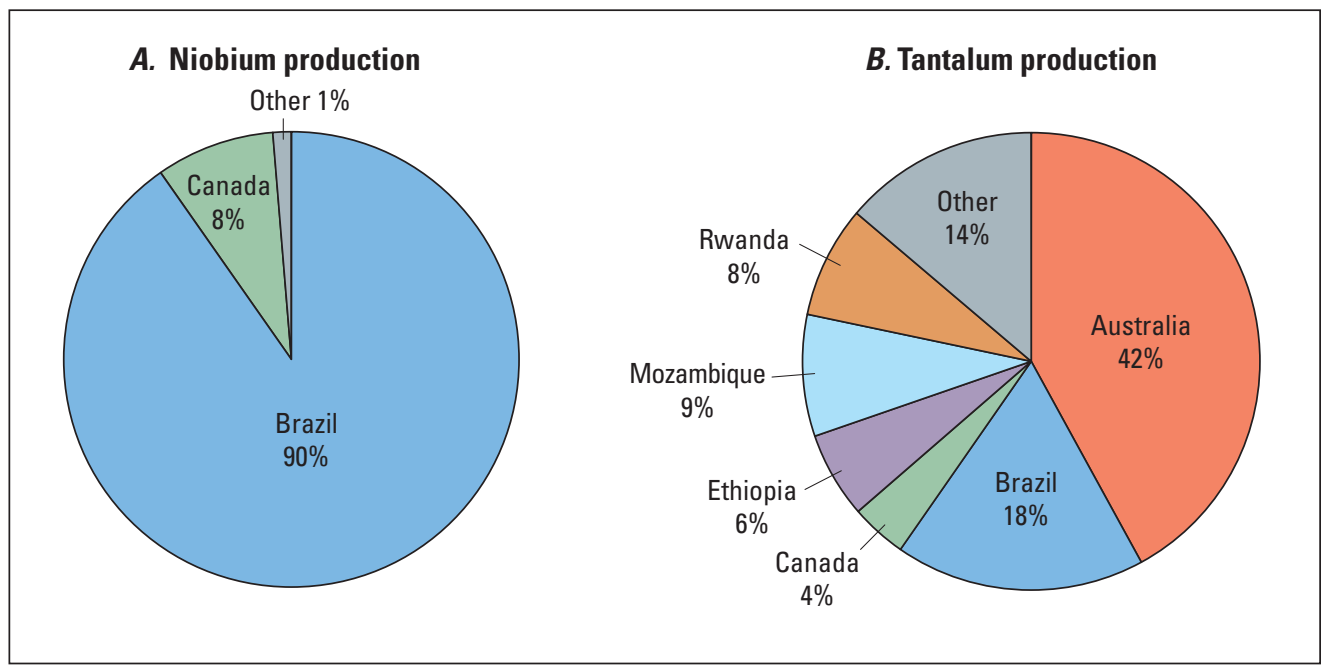

Figure M14. Pie charts showing percentage of average annual world production of $A$, niobium, and $B$, tantalum, for the period 2007-11, by country (Papp, 2013a). Australia and Canada had no reported tantalum production in 2010. The data for Ethiopia are for 2007 only. Percentages have been rounded to no more than two significant figures and do not add to 100 . 


\section{Exploration for New Deposits}

Carbonatites are an important exploration target because of their potential to host large, commonly bulk-minable niobium (with lesser amounts of tantalum) resources. About 80 percent of carbonatites are associated with silicate rocks, the majority of which are highly alkaline (Woolley and Bailey, 2012). Not all alkaline complexes and provinces contain carbonatites, however. Carbonatites are preferentially concentrated in Precambrian terranes and are associated with intracontinental rifts, such as the East African rift system (Bailey, 1974). Their common circular plan and concentric arrangement of alkaline rocks can be identified and mapped by standard geologic-mapping techniques in areas with surface rock exposures. In remote areas and covered areas, geophysical surveys, including magnetic, gravity, and electrical methods, play a critical role in exploration. The natural association of carbonatites with uranium, thorium, and potassium also makes airborne radiometric surveys a useful exploration tool. Once a target has been identified, conventional exploration procedures are used in evaluating niobium and tantalum resources, including detailed ground geophysical surveys, and trenching, drilling, and chemical analysis. Niobium and tantalum minerals typically are not easily identified and can require laboratory analysis for confirmation. In addition, the insoluble and refractory character of niobium and tantalum can require special analytical methods.

LCT-type pegmatites generally occur along large regional-scale faults in low to moderately metamorphosed terranes with mafic volcanic and sedimentary host rocks (Selway and others, 2005). The largest deposits are in Archean crust. Initial exploration typically involves a search for rare-metal peraluminous granite intrusions that can serve as the source of pegmatites. Rare-metal granites are identified by (a) high rare-metal contents (which are at least three times the average crustal abundances); (b) magnesium to lithium (Mg:Li) ratios less than 10; and (c) niobium to tantalum (Nb:Ta) ratios less than 8 (Selway and others, 2005). These granites are also characterized by white potassium feldspar, green coarse-grained mica, and distinctive accessory minerals (such as cordierite, fluorapatite, garnet, and (or) tourmaline). Rare-metal pegmatites may be found in an aureole above the granite, with the most enriched pegmatites generally the farthest (up to $10 \mathrm{~km}$ ) from the granite body. Altered country rocks can be an indication of rare-metal pegmatite bodies nearby and may contain elevated contents of boron, cesium, fluorine, lithium, and rubidium that are detectable in geochemical surveys. Pegmatites with potential to host a tantalum deposit generally have low $\mathrm{Nb}$ :Ta ratios $(<8)$ and tantalum to tin (Ta:Sn) ratios of $>1$ in bulk analyses, as well as abundant tantalum-rich oxide minerals. As with carbonatites, radiometric surveys can aid in exploration for LCT-type pegmatites.

\section{Environmental Considerations}

\section{Sources and Fate in the Environment}

The main sources of niobium and tantalum in the environment are geologic, mostly as a result of the weathering of rocks, but a potential anthropogenic source of both is from the combustion of coal (Divine and Goering, 2004; Goering and Ziegler, 2004). Tantalum compounds are less mobile than niobium compounds, which are slightly soluble under both acid and alkaline conditions and in the presence of organic complexing agents (Kabata-Pendias and Mukherjee, 2007). Gaillardet and others (2003) reported worldwide average dissolved concentrations in river waters of 2 parts per trillion (ppt) niobium and $1 \mathrm{ppt}$ tantalum. Globally, the average concentration in suspended sediments in rivers is $13.5 \mathrm{ppm}$ for niobium and $1.3 \mathrm{ppm}$ for tantalum (Viers and others, 2009). Also, surface (0 to 5 centimeters depth) soils from the conterminous United States contain an average of $9.3 \mathrm{ppm}$ niobium and range from less than $1 \mathrm{ppm}$ to $80.1 \mathrm{ppm}$; values for tantalum were not reported (Smith and others, 2013).

The concentrations of some elements may be naturally enriched in soils, sediments, and waters in the vicinity of niobium and tantalum deposits before mining begins; knowledge of these geochemical anomalies is used as an exploratory tool as well as to set realistic remediation goals after mining. The geochemical signatures around the deposits depend on the type of deposit and the compositions of associated rocks. Stream water and groundwater near deposits may not display the same geochemical signature as soils and stream sediments because some of the enriched elements occur in relatively stable insoluble minerals. In general, soils derived from various alkaline rock types commonly contain increased levels of niobium (up to $300 \mathrm{ppm}$ ) (Ure and others, 1979). The niobium in the soils can be taken up by plants, such as in the Gumi region of Russia where the niobium content (up to $10 \mathrm{ppm}$ ) of certain plant species has served as an exploration indicator for niobium deposits (Kabata-Pendias and Pendias, 2001). Soils and weathered rock associated with carbonatite deposits may be naturally enriched in $\mathrm{Fe}, \mathrm{Ba}, \mathrm{Nb}, \mathrm{P}, \mathrm{Th}, \mathrm{Ti}, \mathrm{U}, \mathrm{Zr}$ and REEs. Additionally, stream sediments downstream from deposits commonly contain anomalous abundances of $\mathrm{Ba}, \mathrm{Nb}, \mathrm{Th}$, and REEs (Modreski and others, 1995). LCT-type pegmatite deposits may exhibit enrichments in $\mathrm{B}, \mathrm{Cs}, \mathrm{F}, \mathrm{Li}$, and $\mathrm{Rb}$ in surrounding soils and waters because these elements tend to alter country rock during pegmatite emplacement (Bradley and McCauley, 2013). For example, the Tanco pegmatite in Canada has alteration halos of $\mathrm{Li}$ and $\mathrm{Rb}$ over the buried deposit (Trueman and Černý, 1982). In addition, Smith and others (1987) reported that zones of enriched As, Be, Sb, and $\mathrm{Sn}$, and of $\mathrm{B}, \mathrm{Nb}$, and $\mathrm{Ta}$ are found in lateritic soils around the Greenbushes pegmatite. 
Globally, niobium metal is one of 18 elements with a greater than 50 percent end-of-life recycling rate, which is the proportion of the element in a discarded product that is able to be used to generate a new product. In contrast to niobium, less than 1 percent of discarded tantalum metal or alloy is used to generate a new product worldwide. Tantalum is used in small quantities in complex products, such as electronics, which makes recycling technically difficult. To recover more tantalum from consumer products, additional separation in the collection and presorting of the electronics would need to be done (Graedel and others, 2011). The recycled content of products containing niobium and tantalum is high, at greater than 50 percent for niobium and between 10 and 25 percent for tantalum (Graedel and others, 2011). According to Papp (2013a), scrap recovery specifically for niobium was negligible, but significant amounts of niobium were recycled from niobium-bearing steels and superalloys. Tantalum was recycled mostly from new scrap generated during the manufacturing of cemented carbide, electronics, and superalloys.

\section{Mine Waste Characteristics}

Mine waste is generally considered to be the material generated during ore extraction and processing at the mine site that has no economic value. The volume and characteristics of the waste materials depend on the type of deposit and its size, the mineral commodity or commodities recovered, and the mining and processing methods used. Niobium and tantalum ores are treated similarly and commonly are crushed and ground before mineral separation, which may involve dry and wet gravity separation, dry screening, magnetic separation, flotation, acid leaching, and, sometimes, smelting, to remove impurities and concentrate the niobium and (or) tantalum. The removal of overburden and ore extraction and processing operations generate waste rock, tailings, and slag, which are commonly disposed of on site in dumps or in tailings ponds. The amount of waste produced at the mine sites may be significant relative to the amount of niobium or tantalum recovered because of the low grades of the ores; however, the recovery of additional commodities can reduce the waste volume.

The mining and processing of niobium and tantalum deposits commonly generates various types of waste, some with unique compositions. One example of mine waste generated from an LCT-type pegmatite deposit is waste from the Greenbushes Mine in Australia where the various ore minerals are extracted and processed separately to recover either lithium or tin and tantalum. Processing the tin-tantalum ores generates tailings composed mainly of gangue minerals (that is, predominantly quartz and feldspars). Minor amounts of antimony and sulfides are removed by flotation and roasting, and smelting is done to separate the tantalum from the tin (Fetherston, 2004); these processes create tailings and slag waste. In addition, overburden rock consisting predominantly of quartz ( 35 to 45 percent) and kaolinite ( 35 to 60 percent) is used to cover waste rock dumps to aid in rehabilitation (Hearman and Hinz, 2004).

Another example of the variety of waste generated from processing LCT-type pegmatite ore is the waste from the underground Tanco Mine in Manitoba, Canada. At this site, tantalum is processed by gravity concentrations, spodumene is processed mainly by flotation, and pollucite is treated chemically. The wastes generated include tailings and waste rock that are generally composed of the predominant gangue minerals of feldspar and quartz. For comparison to the LCT-type pegmatite deposits, mine waste generated from exploiting niobium-enriched carbonatites is usually some combination of the following common gangue minerals: amphiboles, ankerite, apatite, calcite, dolomite, magnetite, micas, pyroxenes, and olivine, among others. Mine waste from one processing step at the Araxá Mine in Brazil is predominantly hematite and magnetite; trace amounts of anatase, apatite, barite, and sulfides are likely present (Silva and others, 2012). Similar to ore from the Araxá Mine, niobium ores from the Niobec Mine in Quebec, Canada, are extracted and processed in several steps, and each generates waste of a different composition. Flotation and desliming generates carbonate-rich tailings; magnetic separation generates magnetite waste; and additional flotation generates a sulfide waste containing pyrite (Fetherston, 2004).

In general, tailings and waste produced from niobium and tantalum deposits may contain significant concentrations of uranium and (or) thorium and their daughter radionuclides. For example, tailings from the Jos area of Nigeria contain up to 4 weight percent thorium and up to 0.2 weight percent uranium (Funtua, 2001). The smelting and some chemical processes (acid leaching) of niobium ores from two operations in Brazil significantly enrich the waste in radionuclides; however, the prior physical processing (that is, magnetic separation, desliming, and flotation) of these particular ores does not significantly alter the radionuclide content of the waste compared with that of the ore (Pires do Rio and others, 2003). Also, the chemical treatment of phosphate ores from carbonatite deposits in Brazil (for example, Araxá, Catalão, and Tapia) generates waste with high radioactivity (concentrations of up to hundreds of kilobecquerels per kilogram of radium as ${ }^{226} \mathrm{Ra}$ ) (Paschoa, 1998). Although the activities of uranium and thorium in ore from the Greenbushes Mine in Australia are generally low (less than 60 becquerels per kilogram $(\mathrm{Bq} / \mathrm{kg})$ of uranium and less than $5 \mathrm{~Bq} / \mathrm{kg}$ of thorium), processing the ore may generate enriched waste and concentrates, such that tantalum products contain from 7.5 to 75 kilobecquerels per kilogram $(\mathrm{kBq} / \mathrm{kg})$ of uranium and thorium (Cooper, 2005). The volume of radionuclide-enhanced waste generated at the mine sites can be significant, such as at the Pitinga tintantalum-niobium mine in Brazil, where at least 10,000 metric tons of naturally occurring radioactive wastes are disposed of every year (Paschoa, 1998). 


\section{Human Health Concerns}

Niobium and tantalum are generally considered nonessential for humans and have low toxicity (Reimann and de Caritat, 1998). Because of their relative biological inertness, both, but in particular tantalum, are used in a variety of medical devices and surgical implants (Divine and Goering, 2004; Kabata-Pendias and Mukherjee, 2007). Tantalum is absorbed only minimally by the human body from oral or inhalation exposure; nearly all the tantalum that enters the human body is eliminated within a relatively short period of time. Humans exposed to large amounts of tantalum metal or to its oxide dusts may experience eye and skin irritation. Also, there is some evidence that tantalum can cause tumors (Divine and Goering, 2004). The permissible exposure limits in the United States for tantalum metal and oxide dust for an 8-hour work day is 5 milligrams per cubic meter $\left(\mathrm{mg} / \mathrm{m}^{3}\right)$ and is based on lung irritation (Occupational Safety and Health Administration, 2013). Although data are sparse and studies on humans lacking, niobium is likely similar to tantalum in that its retention time in the human body is usually relatively short, and much of it is eliminated unabsorbed (Goering and Ziegler, 2004). Studies have shown, however, that small mammals that ingested niobium compounds in drinking water had a shortened lifespan. Niobium has been shown to be associated with tumors, but is not mutagenic (Goering and Ziegler, 2004, and references therein). Niobium is considered hazardous by the Occupational Safety and Health Administration (OSHA), but OSHA has not established a permissible exposure limit for niobium dust (Occupational Safety and Health Administration, 2013).

Although niobium and tantalum may not be the cause of significant human health concerns, industrial exposure to naturally occurring radioactive materials from enhanced levels of thorium and uranium during the processing of niobium and tantalum ores may be a concern. Occupational exposure can take place from external radiation and from inhaling and ingesting radioactive particles generated during mining and milling. Smokers, who inhale twice or more the amount of radon than do nonsmokers, have an increased risk for exposure (Mangset and Sheyin, 2009). In Congo (Kinshasa), the grinding and sieving of columbite-tantalite ores during artisanal mining has been shown to expose workers to high doses of radioactivity (Mustapha and others, 2007).

Humans living near mining and processing operations may also be exposed to technically enhanced naturally occurring radioactive materials. Exposure may be a concern from waste materials used for building construction and from drinking water or eating foods contaminated with radiation. Slag and acid-leaching wastes (mostly barium sulfate) disposed of in alternating layers in waste dumps at a niobium processing facility in Brazil yielded higher radionuclide concentrations than did ores and other waste materials, and doses associated with them exceed international exposure guidelines. Also, the doses of radiation from treated effluent and drainage from waste ponds were lower than local limits but higher than some international exemption levels (Pires do Rio and others, 2003). In Nigeria, mining tin, tantalum, and niobium from placer deposits and weathered granites has resulted in large amounts of radioactive tailings dumped in and around mine sites (Funtua, 2001). The activities of radionuclides of radium and thorium in tin tailings, especially those containing significant monazite and zircon, and soils $500 \mathrm{~m}$ from the tailings were higher than background activities, and the estimated annual effective doses to the population were much higher than the recommended levels (Usikalu and others, 2011). In addition to being radioactive, tin-niobium-tantalum tailings from the Jos area of Nigeria contained concentrations of lead, manganese, and tin that exceeded soil screening levels based on residential and industrial use in the United States; these levels are used to determine whether contamination at hazardous waste sites warrant further investigation or site cleanup (Funtua, 2001; U.S. Environmental Protection Agency, 2012). After operations have ended at niobium and tantalum mines and processing sites, the use of the land may need to be restricted to minimize human exposure to radiation and high concentrations of some trace elements.

\section{Ecological Health Concerns}

Ecological health concerns associated with niobium and tantalum are generally minimal under most naturally occurring conditions. Niobium may accumulate in plants and is generally less than $0.4 \mathrm{ppm}$ dry weight in terrestrial plants from background locations and greater than $1 \mathrm{ppm}$ in plants growing near niobium deposits (Goering and Ziegler, 2004). According to one recent study, the toxicity of niobium and tantalum to freshwater amphipods (Hyalella azteca) was relatively low compared with that of other trace elements tested in laboratory experiments; 1 -week lethal concentrations of hundreds of ppb niobium and tantalum resulted in significant mortality for amphipods in soft waters, whereas those in hard waters were not affected until concentrations reached thousands of ppb (Borgmann and others, 2005).

The mining and processing of niobium and tantalum ores may have a deleterious effect on terrestrial and aquatic plants and organisms from the release of trace elements and (or) radionuclides associated with the ore or host rock into the surrounding ecosystem. If sulfides are present, even in minor to trace quantities, they can oxidize, generate acid, and exacerbate the release of trace elements; however, rocks that contain carbonates can help mitigate some deleterious effects naturally. Metal-rich and radioactive mine waste can be physically transported into local waterways, and fine-grained tailings dust and emissions from ore processing sites can be 
transported in the air for long distances; these processes can result in contaminated soils, waters, and stream sediments. The mining and processing of the ore may take place at the same location, and emissions from the processing and smelting may contain toxic elements and substances that can be released into the air and surrounding soils and waterways.

A few studies of niobium and tantalum mine sites have reported potential ecological health concerns. In Rwanda, the concentrations of arsenic in stream sediments downstream of Ruhanga and at the Nyatubindi tin-niobium-tantalum mine and lead in stream sediments at the Ruhanga site were above the threshold effect concentrations for aquatic organisms (that is, the concentrations below which effects are not likely to occur) but below probable effect concentrations (that is, the concentrations above which effects are likely to occur), which suggests potential impact to biota (MacDonald and others, 2000; Haidula and others, 2011). Also, rare but extreme mine water compositions existed within the mine workings at the Lovozero Mine. Waters were highly alkaline ( $\mathrm{pH}$ range of 10 to 12 ), enriched in fluorine (1 to 1.5 percent) and silica (1 to 1.3 percent), and contained high amounts of aluminum (up to 1,000 ppm), copper (up to 900 parts per billion [ppb]), niobium (up to $400 \mathrm{ppb}$ ), and REEs (greater than $600 \mathrm{ppb}$ ); the concentrations of aluminum and copper exceeded guidelines for aquatic ecosystem health in the United States (Kraynov and others, 1969; U.S. Environmental Protection Agency, 2013). In addition to these studies, Paschoa (1998) reported significant radioactivity (approximately $100 \mathrm{kBq} / \mathrm{kg}$ of ${ }^{226} \mathrm{Ra}$ ) for fine-grained tailings at the Araxá Mine in Brazil. Tailings are disposed of in waste ponds, thus contaminating the water (approximately 20 kilobecquerels per cubic meter of ${ }^{226} \mathrm{Ra}$ ) (Paschoa, 1998). Concentrations above 1 to $10 \mathrm{kBq} / \mathrm{kg}$, depending on the radionuclide, warrant special consideration for disposal of solid material, which may need to be buried in low-level radioactive waste disposal facilities. Beside reports of radioactivity and some high concentrations of elements, mine waste and mine waters generated at some niobium and tantalum mine sites are not of ecological health concern. For example, processing water and tailings runoff and discharge released into the environment at the world's largest pegmatitehosted tantalum resource, the Greenbushes Mine, is monitored to ensure compliance with internationally developed standards (Ingham and others, 2012). The mine waste generated from pegmatite deposits, although possibly not an issue chemically, may pose ecological health concerns because of the extensive amount of waste disposed of at the sites.

\section{Carbon Footprint}

The carbon footprint of niobium centers on its use in the production of biofuels. Niobium catalysts have recently proved to be successful in the conversion of palm oil to biodiesel. In Brazil, one large mining company has developed palm oil plantations to supply its own biodiesel needs (Schwela, 2010). The use of biofuels decreases greenhouse gas emissions compared with the use of petroleum fuels; however, whether first-generation biofuels have a less substantial carbon footprint than petroleum when other factors are taken into consideration remains controversial. Such other factors include the amount of energy consumed to convert plants to biofuel, the opportunity cost of using land to grow crop plants for biofuels that is then not available to grow food for humans and animals, and the potential increase in the amount of forest land that may be cleared to grow biofuel crops.

\section{Mine Closure}

The postmining landscape at niobium and tantalum mines depends on the type and size of the deposit, the mining and processing methods used, the mineral commodity or commodities recovered, the climate, and the relevant regulations regarding mine closure. Extraction from large igneous complexes by open pit methods, which is the most common mining method used, will leave a distinctly different signature than recovery from small artisanal mining of secondary placer deposits or weathered pegmatites. For example, the active Greenbushes Mine in Australia, which has been mined intermittently since 1888, consists of a complex landscape of several open pits, underground workings, waste rock piles, and tailings piles (Ingham and others, 2012). The largest open pit is the Cornwall Pit, which is more than $200 \mathrm{~m}$ deep. The closure cost for this site was estimated to be more than $\$ 17$ million to rehabilitate nearly 2,000 hectares of disturbed land (Ingham and others, 2012).

Artisanal and small-scale mining, such as that conducted in central Africa, is typically unregulated, and environmental issues are commonly not considered. Many such mining operations do not have mine closure plans and are left as is after recoverable ore is extracted. For example, tin (and tantalum-niobium) mining in the Jos area of Nigeria has drastically changed the landscape, and little has been done in the way of remediation efforts. Some detrimental effects of the altered landscape include disturbances of the natural flora and fauna, low crop yields on agricultural lands, local land disputes from soil erosion problems, and neglected mine excavations, mine dumps, and pits. On the other hand, flooded mine pits are a source of water for irrigation as well as for domestic and livestock uses. They can also provide sites for potential fisheries (Abegboye, 2012). Future measures may focus on remediating the affected land back to productive farm land. 


\section{Problems and Future Research}

Consumption of niobium and tantalum is expected to increase in the coming years as industrial development in such countries as Brazil, China, and India continues, and the rapidly increasing global population demands more consumer goods, such as cars, cell phones, computers, and other high-tech products. Although the estimated reserves and resources of both niobium and tantalum are large and appear more than sufficient to meet global demand for the foreseeable future (British Geological Survey, 2011), the restricted concentration of niobium resources and production, and, to a lesser extent, those of tantalum, makes their stable supply vulnerable to potential influence and disruption. The United States currently lacks domestic self-sufficiency for both mineral commodities and is dependent on imports and recycling to meet its current and future needs. For the United States, the discovery of additional deposits of niobium and tantalum of better quality and quantity than those currently identified would be advantageous. New discoveries in the United States, particularly of niobium, may be facilitated by ongoing efforts to identify additional REE resources because alkaline and carbonatite complexes can host both deposit types.

An issue of international concern specific to tantalum is the mining of columbite-tantalite (also called coltan) in central Africa, particularly in Congo (Kinshasa). Militias implicated in human rights abuses are accused of using the sale of columbite-tantalite and other mineral commodities to help fund a civil war in Congo (Kinshasa). In 2010, the U.S. Government passed the Dodd-Frank Wall Street Reform and Consumer Protection Act. Section 1502 of that Act directs that companies that report to the U.S. Securities and Exchange Commission must reveal whether they buy minerals from Congo (Kinshasa) or any of its neighbors and, if so, whether conflict minerals exist in their supply chain. This has led to efforts to develop a system that can trace the origin of columbite-tantalite ore from the region (Burt, 2012). A program related to establishing a conflict-free supply chain for columbite-tantalite was launched by the International Tin Research Institute in 2011 in Rwanda and the Katanga Province of Congo (Kinshasa), with baseline studies of almost 500 mine sites completed (Burt, 2012). This program (the Tin Supply Chain Initiative, or iTSCi) is attempting to identify legitimate mines, with the overall goal being to provide a way to exclude illegal columbite-tantalite from the conventional market while discerning legitimate small-scale artisanal mine production in central Africa.

Geologically, there are still many unanswered questions about the origin of niobium and tantalum deposits, including (a) why some carbonatites are enriched in niobium and others are enriched in REEs; (b) what is the role of fluids in the mobilization and concentrations of niobium and tantalum; (c) why are the largest pegmatite-hosted tantalum deposits of Archean age; and (d) are there additional types of tantalum deposits, particularly low-grade large-tonnage commercial deposits?

\section{References Cited}

Note: All Web links listed were active as of the access date but may no longer be available.

Abegboye, M.A., 2012, Effect of mining on farming in Jos South local government area of Plateau State: Journal of Soil Science and Environmental Management, v. 3, no. 4, p. $77-83$.

Alkane Resources Ltd., 2012, Annual report 2011: Perth, Western Australia, Australia, Alkane Resources Ltd., 56 p., accessed July 27, 2015, at http://www.alkane.com.au/pdf/ annual-reports/2011_Alkane_AR_SWF/Alkane_2011_AR_ Interactive.html.

Anglo American plc, 2012, Annual report 2011: London, United Kingdom, Anglo American plc, 212 p., accessed April 9, 2014, at http://ar11.angloamerican.com/_assets/ pdf/final/AA_AR2011.pdf.

Bailey, D.K., 1974, Continental rifting and alkaline magmatism, in Sørensen, Henning, ed., The alkaline rocks: New York, N.Y., Wiley Interscience, p. 148-159.

Barker, D.S., 1974, Alkaline rocks of North America, in Sørensen, Henning, ed., The alkaline rocks: New York, N.Y., Wiley Interscience, p. 160-171.

Barker, D.S., 1989, Field relations of carbonatites, in Bell, Keith, ed., Carbonatites - Genesis and evolution: London, United Kingdom, Unwin Hyman, p. 38-69.

Barton, W.R., 1962, Columbium and tantalum, a materials survey: U.S. Bureau of Mines Information Circular 8120, $110 \mathrm{p}$.

Bastos Neto, A.C., Pereira, V.P., Ronchi, L.H., de Lima, E.F., and Frantz, J.C., 2009, The world-class Sn, Nb, Ta, F (Y, REE, Li) deposit and the massive cryolite associated with the albite-enriched facies of the Madeira A-type granite, Pitinga mining district, Amazonas State, Brazil: Canadian Mineralogist, v. 47, no. 6, p. 1329-1357. [Also available at http://dx.doi.org/10.3749/canmin.47.6.1329.]

Belzile, Elzéar, 2009, NI 43-101 technical report for Niobec Mine, Quebec, Canada, prepared for IAMGOLD Corp. [Filing date March 9, 2009]: Toronto, Ontario, Canada, Belzile Solutions Inc., February 2009, 104 p. [Also available at http://www.sedar.com.]

Berger, V.I., Singer, D.A., and Orris, G.J., 2009, Carbonatites of the world, explored deposits of $\mathrm{Nb}$ and REE-Database and grade and tonnage models: U.S. Geological Survey Open-File Report 2009-1139, 17 p. [Also available at http://pubs.usgs.gov/of/2009/1139/.] 
Bleiwas, D.I., Papp, J.F., and Yager, T.R., 2015, Shift in global tantalum mine production, 2000-2014: U.S. Geological Survey Fact Sheet 2015-3079, 6 p.

Borgmann, Uwe, Couillard, Yves, Doyle, Patrick, and Dixon, D.G., 2005, Toxicity of sixty-three metals and metalloids to Hyalella azteca at two levels of water hardness: Environmental Toxicology and Chemistry, v. 24, no. 3, p. 641-652. [Also available at http://dx.doi.org/10.1897/04-177R.1.]

Bradley, Dwight, and McCauley, Andrew, 2013, A preliminary deposit model for lithium-cesium-tantalum (LCT) pegmatites: U.S. Geological Survey Open-File Report 2013-1008, 7 p. [Also available at http://pubs.usgs.gov/of/2013/1008/.]

British Geological Survey, 2011, Niobium-tantalum: Keyworth, Nottingham, United Kingdom, British Geological Survey Mineral Profile, April, 27 p., accessed April 19, 2012, at http://www.bgs.ac.uk/mineralsuk/ statistics/mineralProfiles.html.

Burt, Richard, 2012, A conflict-free supply chain-An update: Tantalum-Niobium International Study Center Bulletin, no. 149 , p. 1-2.

Cameron, E.N., Jahns, R.H., McNair, A.H., and Page, L.R., 1949, Internal structure of granitic pegmatites: Urbana, Ill., Economic Geology Publishing Co., Monograph 2, 155 p., folded maps.

Černý, Petr, 1991a, Rare-element granitic pegmatites, part IRegional to global environments and petrogenesis:

Geoscience Canada, v. 18, no. 2, p. 49-67.

Černý, Petr, 1991b, Rare-element granitic pegmatites, part IIRegional to global environments and petrogenesis: Geoscience Canada, v. 18, no. 2, p. 68-81.

Černý, Petr, 2005, The Tanco rare-element pegmatite deposit, Manitoba-Regional context, internal anatomy, and global comparisons, in Linnen, R.L., Samson, I.M., and Martin, R.F., eds., Rare-element geochemistry and mineral deposits: St. Johns, Newfoundland and Labrador, Canada, Geological Association of Canada, Short Course Notes, v. 17, p. 127-158.

Černý, Petr, and Ercit, T.S., 2005, The classification of granitic pegmatites revisited: Canadian Mineralogist, v. 43, no. 6, p. 2005-2026. [Also available at http://dx.doi.org/10.2113/ gscanmin.43.6.2005.]

Chong, Albert, and Postolski, Tomasz, 2011, Blue River Ta-Nb Project, NI 43-101 Technical Report: Vancouver, British Columbia, Canada, AMEC Americas Ltd., January 31, accessed April 9, 2014, at http:/www.commerceresources.com/i/pdf/ NI43-101Report-BlueRiver.pdf.
Cooper, M.B., 2005, Naturally occurring radioactive materials (NORM) in Australian industries - Review of current inventories and future generation: Stirling, Scotland, United Kingdom, EnviroRad Services Pty. Ltd., ERS-006, accessed April 2, 2013, at http://arpansa.gov.au/pubs/norm/ cooper_norm.pdf.

Cordeiro, P.F.O., Brod, J.A., Palmieri, Matheus, Oliveira, C.G., Barbosa, E.S.R., Santos, R.V., Gaspar, J.C., and Assis, L.C., 2011, The Catalão I niobium deposit, central BrazilResources, geology, and pyrochlore chemistry: Ore Geology Reviews, v. 41, no. 1, p. 112-121. [Also available at http://dx.doi.org/10.1016/j.oregeorev.2011.06.013.]

Cox, J.J., Ciuculescu, Tudorel, Goode, J.R., and Hains, D.H., 2011, Technical report on the Thor Lake project, Northwest Territories, Canada, NI 43-101 technical report, prepared for Avalon Rare Metals Inc.: Toronto, Ontario, Canada, Roscoe Postel Associates, Inc., August 25, 293 p., accessed April 21, 2014, at http://www.avalonraremetals.com/ resources/reports/RPA_Avalon_Thor_Lake_NI_43-101_ August_25_2011.pdf.

Crockett, R.N., and Sutphin, D.M., 1993, International strategic mineral inventory summary report-Niobium (columbium) and tantalum: U.S. Geological Survey Circular 930-M, 36 p.

Daigle, Paul, 2012, Elk Creek Nb Project, Nebraska, US resource estimate update, NI 43-101 report prepared for Quantum Rare Earth Developments Corp.: Toronto, Ontario, Canada, Tetra Tech Wardrop, 143 p., accessed October 15, 2012, at http:/www.quantumrareearth.com/ projects.html.

Divine, K.K., and Goering, P.L., 2004, Tantalum, chap. 21 of Merian, Ernest, Anke, Manfred, Ihnat, Milan, and Stoeppler, Markus, eds., Elements and their compounds in the environment-Occurrence, analysis and biological relevance ( $2 \mathrm{~d}$ ed.): Weinheim, Germany, Wiley-VCH Verlag $\mathrm{GmbH}$, p. 1087-1097. [Also available at http://dx.doi.org/ 10.1002/9783527619634.ch42.]

European Commission, 2010, Critical raw materials for the EUReport of the ad-hoc Working Group on defining critical raw materials: Brussels, Belgium, European Commission, July, 85 p., accessed June 28, 2012, at http://ec.europa.eu/ enterprise/policies/raw-materials/files/docs/report-b_en.pdf. [Critical raw materials list was updated in 2014; see http://ec.europa.eu/growth/sectors/raw-materials/specificinterest/critical/index_en.htm.] 
Fetherston, J.M., 2004, Tantalum in Western Australia: Geological Survey of Western Australia, Mineral Resource Bulletin 22, 162 p., 1 folded map in pocket, accessed April 9, 2014, at http://www.commerceresources.com/ i/pdf/10-Complete.pdf.

Funtua, I.I., 2001, Elemental composition of Sn-Nb-Ta mine tailings of Jos area, central Nigeria: Chemie der ErdeGeochemistry, v. 61, no. 1, p. 45-53.

Gaillardet, J., Viers, J., and Dupré, B., 2003, Trace elements in river waters, in Drever, J.I., ed., Surface and ground water, weathering, and soils, v. 5 of Holland, H.D., and Turekian, K.K.,eds., Treatise on geochemistry: Oxford, United Kingdom, Elsevier-Pergamon, p. 225-272. [Also available at http://dx.doi.org/10.1016/B0-08-0437516/05165-3.]

Galaxy Resources Ltd., 2012, Annual report 2011: West Perth, Western Australia, Australia, Galaxy Resources Ltd., 103 p., accessed September 23, 2015, at http:/www.galaxyresources.com.au/Investor/Company_ Reports.htm

Gippsland Ltd., 2011, Annual report 2011: Claremont, Western Australia, Australia, Gippsland Ltd., 82 p., accessed April 9, 2014, at http:/www.gippslandltd.com/upload/ docs/111027_Gippsland_AR_2011_LowRes_sml.pdf.

Global Mining Services Pty Ltd., 2009, Technical report on the mineral assets of Tantalum Mineração and Prospecção Limitada-NI 43-101 technical report, prepared for Pacific Wildcat Resources Corp. [Filing date May 25, 2009]: Vancouver, British Columbia, Canada, Global Mining Services Pty Ltd., April 30, 86 p. plus 2 appendixes, accessed April 21, 2014, at http://www.pacificwildcat.com/_ content/documents/387.pdf.

Goering, P.L., and Ziegler, T.L., 2004, Niobium (Nb) (columbium), chap. 19 of Merian, Ernest, Anke, Manfred, Ihnat, Milan, and Stoeppler, Markus, eds., Elements and their compounds in the environment-Occurrence, analysis and biological relevance ( $2 \mathrm{~d}$ ed.): Weinheim, Germany, WileyVCH Verlag GmbH, v. 2, p. 1039-1046. [Also available at http://dx.doi.org/10.1002/9783527619634.ch40.]

Graedel, T.E., Allwood, Julian, Birat, J.-P., Buchert, Matthias, Hagelüken, Christian, Reck, B.K., Sibley, S.F., and Sonnemann, Guido, 2011, What do we know about metal recycling rates?: Journal of Industrial Ecology, v. 15, no. 3, p. 355-366. [Also available at http://dx.doi.org/ 10.1111/j.1530-9290.2011.00342.x.)

Grice, J.D., Černý, Petr, and Ferguson, R.B., 1972, The Tanco pegmatite at Bernic Lake, Manitoba-IIWodginite, tantalite, pseudo-ixiolite and related minerals: Canadian Mineralogist, v. 11, p. 609-642.
Haidula, A.F., Ellmies, Rainer, and Kayumba, Francis, 2011, Environmental monitoring of small-scale mining areas in Rwanda: Kigali, Rwanda, Rwanda Natural Resources Authority, accessed April 8, 2013, at http://rnra.rw/fileadmin/ user_upload/documents/Rwanda_Environment_ASM_ report_2011-09-20x.pdf.

Hearman, A.J., and Hinz, Christoph, 2004, Soil colour as a indicator of erosions risk on an overburden materials at Greenbushes Mine in Western Australia, in SuperSoil 2004 - 3d Australian New Zealand Soils Conference, University of Sydney, Australia, December 5-9, 2004 [program and abstracts]: Gosford, New South Wales, Australia, The Regional Institute Ltd. [Also available at http://www.regional.org.au/ au/asssi/supersoil2004/s8/oral/1477_hearmanaj.htm.]

IAMGOLD Corp., 2012, Unlocking shareholder valueAnnual report 2011: Toronto, Ontario, Canada, IAMGOLD Corp., 28 p., accessed October 23, 2012, at http:/www.iamgold.com/files/doc_financials/2011/annual/ Annual-Report_2011-(2).pdf.

Ingham, P.D., White, I.R., and Jackson, S., 2012, Greenbushes lithium operations, NI 43-101 technical report, prepared for Talison Lithium Limited [Filing date December 21, 2012]: North Sydney, New South Wales, Australia, Behre Dolbear Australian Pty Ltd., December 21, 104 p., accessed February 7, 2013, at http:/www.talisonlithium.com/docs/ investors-centre-documents/ni-43-101-techreportgreenbushesfinal-dec12-copy.pdf.

Kabata-Pendias, Alina, and Mukherjee, A.B., 2007, Trace elements from soil to human: Berlin, Germany, SpringerVerlag, $550 \mathrm{p}$.

Kabata-Pendias, Alina, and Pendias, Henryk, 2001, Trace elements in soils and plants ( $3 \mathrm{~d}$ ed.): Boca Raton, Fla., CRC Press, 413 p.

Kelemen, P.B., Hanghøj, K., and Greene, A.R., 2003, One view of the geochemistry of subduction-related magmatic arcs, with an emphasis on primitive andesite and lower crust, in Rudnick, R.L., ed., The crust, v. 3 of Holland, H.D., and Turekian, K.K., eds., Treatise on geochemistry: Oxford, United Kingdom, Elsevier-Pergamon, v. 3, p. 593-659. [Also available at http:/www.sciencedirect.com/science/ article/pii/B0080437516030358.]

Kogarko, L.N., Lahaye, Y., and Brey, G.P., 2010, Plumerelated mantle source of super-large rare metal deposits from the Lovozero and Khibina massifs on the Kola Peninsula, eastern part of the Baltic Shield-Sr, Nd, and Hf isotope systematics: Mineralogy and Petrology, v. 98, nos. 1-4, p. 197-208. [Also available at http://dx.doi.org/ 10.1007/s00710-009-0066-1.] 
Kogarko, L.N., Williams, C.T., and Woolley, A.R., 2002, Chemical evolution and petrogenetic implications of loparite in layered, agpaitic Lovozero complex, Kola Peninsula, Russia: Mineralogy and Petrology, v. 74, no. 1, p. 1-24. [Also available at http://dx.doi.org/10.1007/ s710-002-8213-2.]

Kravchenko, S.M., and Pokrovsky, B.G., 1995, The Tomtor alkaline ultrabasic massif and related REE-Nb deposits, northern Siberia: Economic Geology, v. 90, p. 676-689. [Also available at http://dx.doi.org/10.2113/ gsecongeo.90.3.676.]

Kraynov, S.R., Mer'kov, A.N., Petrova, N.G., Baturinskaya, I.V., and Zharikova, V.M., 1969, Highly alkaline (pH 12) fluosilicate waters in the deeper zones of the Lovozero massif: Geochemistry International, v. 6, no. 4, p. 635-640.

Küster, Dirk, 2009, Granitoid-hosted Ta mineralization in the Arabian-Nubian Shield - Ore deposit types, tectonometallogenetic setting and petrogenetic framework: Ore Geology Reviews, v. 35, no. 1, p. 68-86. [Also available at http://dx.doi.org/10.1016/j.oregeorev.2008.09.008.]

Lagache, Martine, and Quéméneur, Joël, 1997, The Volta Grande pegmatites, Minas Gerais, Brazil—An example of rare-element granitic pegmatites exceptionally enriched in lithium and rubidium: Canadian Mineralogist, v. 35, no. 1, p. $153-165$.

Linnen, R.L., and Cuney, Michel, 2005, Granite-related rare-element deposits and experimental constraints on Ta-Nb-W-Sn-Zr-Hf mineralization, in Linnen, R.L., Samson, I.M., and Martin, R.F., eds., Rare-element geochemistry and mineral deposits: St. John's, Newfoundland and Labrador, Canada, Geological Association of Canada, Short Course Notes, v. 17, p. 45-68.

Long, K.R., 2011, The future of rare earth elements-Will these high-tech industry elements continue in short supply?: U.S. Geological Survey Open-File Report 2011-1189, 41 p. [Also available at http://pubs.usgs.gov/of/2011/1189/.]

Long, K.R., Van Gosen, B.S., Foley, N.K., and Cordier, Daniel, 2010, The principal rare earth elements deposits of the United States - A summary of domestic deposits and a global perspective: U.S. Geological Survey Scientific Investigations Report 2010-5220, 96 p. [Also available at http://pubs.usgs.gov/sir/2010/5220.]

Lurie, J., 1986, Mineralization of the Pilanesberg alkaline complex, in Anhaeusser, C.R., andd Maske, S., eds., Mineral deposits of southern Africa: Johannesburg, South Africa, The Geological Society of South Africa, v. II, p. 2215-2228.
MacDonald, D.D., Ingersoll, C.G., and Berger, T.A., 2000, Development and evaluation of consensus-based sediment quality guidelines for freshwater ecosystems: Archives of Environmental Contamination and Toxicology, v. 39, no. 1, p. 20-31. [Also available at http://dx.doi.org/10.1007/ s002440010075.]

Mackay, D.A.R., and Simandl, G.J., 2014, Geology, market and supply chain of niobium and tantalum-A review: Mineralium Deposita, v. 49, no. 8, p. 1025-1047.

Mangset, W.E., and Sheyin, A.T., 2009, Measurement of radionuclides in processed mine tailings in Jos, Plateau State: Bayero Journal of Pure and Applied Sciences, v. 2, no. 2, p. 56-60. [Also available at http://dx.doi.org/10.4314/ bajopas.v2i2.63765.]

Mariano, A.N., 1989, Nature of economic mineralization in carbonatites and related rocks, in Bell, Keith, ed., Carbonatites - Genesis and evolution: Boston, Mass., Unwin Hyman, p. 149-176.

Marks, M.A.W., Schilling, Julian, Coulson, I.M., Wenzel, Thomas, and Markl, Gregor, 2008, The alkaline-peralkaline Tamazeght Complex, High Atlas Mountains, Morocco-Mineral chemistry and petrological constraints for derivation from a compositionally heterogeneous mantle source: Journal of Petrology, v. 49, no. 6, p. 1097-1131. [Also available at http://dx.doi.org/10.1093/petrology/egn019.]

Matheis, Günter., 1987, Nigerian rare-metal pegmatites and their lithological framework: Geological Journal, v. 22, Supplement S2, p. 271-291. [Also available at http://dx.doi.org/ 10.1002/gj.3350220620.]

MDN Inc., 2012, 2011 annual report: Montreal, Quebec, Canada, MDN Inc., 52 p., accessed July 27, 2015, at http://www.mdn-mines.com/pdf/rapports_financiers/ Rapport_annuel_2011_ENG.pdf/.

Melcher, Frank, Graupner, Torsten, Gäbler, Hans-Eike, Sitnikova, Maria, Henjes-Kunst, Friedhelm, Oberthür, Thomas, Gerdes, Axel, and Dewaele, Stijn, 2015, Tantalum(niobium-tin) mineralisation in African pegmatites and rare metal granites - Constraints from $\mathrm{Ta}-\mathrm{Nb}$ oxide mineralogy, geochemistry and U-Pb geochronology: Ore Geology Reviews, v. 64, January, p. 667-719. [Also available at http://dx.doi.org/10.1016/j.oregeorev.2013.09.003.]

Mitchell, R.H., 2005, Mineralogical and experimental constraints on the origins of niobium mineralization in carbonatites, in Linnen, R.L., Samson, I.M., and Martin, R.F., eds., Rare-element geochemistry and mineral deposits: St. Johns, Newfoundland and Labrador, Canada, Geological Association of Canada, Short Course Notes, v. 17, p. 201-215. 
Modreski, P.J., Armbrustmacher, T.J., and Hoover, D.B., 1995, Carbonatite deposits (Model 10; Singer, 1986a), chap. 6 of du Bray, E.A., ed., Preliminary compilation of descriptive geoenvironmental mineral deposit models: U.S. Geological Survey Open-File Report 95-831, p. 47-49. [Also available at http://pubs.usgs.gov/of/1995/ofr-95-0831/.]

Morris, E.M., 1987, The Cretaceous Arkansas alkali provinceA summary of petrology and geochemistry, in Morris, E.M., and Pasteris, J.D., eds., Mantle metasomatism and alkaline magmatism: Boulder, Colo., Geological Society of America, Special Paper, v. 215, p. 217-234, includes sketch maps. [Also available at http://dx.doi.org/10.1130/SPE215-p217.]

Mustapha, A.O., Mbuzukongira, P., and Mangala, M.J., 2007, Occupational radiation exposures of artisans mining columbite-tantalite in the eastern Democratic Republic of Congo: Journal of Radiological Protection, v. 27, no. 2, p. 187-195. [Also available at http://dx.doi.org/ 10.1088/0952-4746/27/2/005.]

Nasraoui, Mohamed, and Waerenborgh, J.C., 2001, Fe speciation in weathered pyrochlore-group minerals from the Lueshe and Araxá (Barreiro) carbonatites by ${ }^{57} \mathrm{Fe}$ mössbauer spectroscopy: Canadian Mineralogist, v. 39, no. 4, p. 1373-1080. [Also available at http://dx.doi.org/ 10.2113/gscanmin.39.4.1073.]

National Research Council, 2008, Minerals, critical minerals, and the U.S. economy: Washington, D.C., The National Academies Press, 245 p. [Also available at http://www.nap.edu/catalog/12034/minerals-criticalminerals-and-the-us-economy.]

Natural Earth, 2014, Small scale data: Natural Earth map dataset, scale 1:110,000,000, accessed March 25, 2014, at http://www.naturalearthdata.com.

Niocan Inc., 2011, Annual report 2011: Montreal, Quebec, Canada, Niocan Inc., 32 p., accessed April 9, 2014, at http:/www.niocan.com/ww2/images/pdf/FinancialStatements-2011.pdf.

Niu, Yaoling, and O'Hara, M.J., 2003, Origin of ocean island basalts-A new perspective from petrology, geochemistry, and mineral physics considerations: Journal of Geophysical Research, v. 108, no. B4, p. 2209. [Also available at http://dx.doi.org/10.1029/2002JB002048.]

Noventa Ltd., 2011, Annual report and financial statements 2011: St. Helier, Jersey, United Kingdom, Noventa Ltd., 92 p., accessed July 20, 2015, at http://www.paragonresources.com/pr/PDF/docs/20111231-Noventa-LimitedFinancial-Statements.pdf.
Occupational Safety and Health Administration, 2013, Regulations (Standards 29 CFR), Part 1910 Occupational Safety and Health Standards, Toxic and Hazardous Substances: Washington, D.C., U.S. Department of Labor, accessed February 15, 2013, at http:/www.osha.gov/pls/oshaweb/ owadisp.show_document?p_table=standards\&p_id=9992.

Papp, J.F., 2013a, Niobium and tantalum, in Metals and minerals: U.S. Geological Survey Minerals Yearbook 2011, v. I, p. 52.1-52.14. [Also available at http://minerals.usgs.gov/ minerals/pubs/commodity/niobium/.]

Papp, J.F., 2013b, Niobium (columbium): U.S. Geological Survey Mineral Commodity Summaries 2013, p. 110-111. [Also available at http://minerals.usgs.gov/minerals/pubs/ mcs/2013/mcs2013.pdf.]

Papp, J.F., 2013c, Tantalum: U.S. Geological Survey Mineral Commodity Summaries 2013, p. 162-163. [Also available at http://minerals.usgs.gov/minerals/pubs/mcs/2013/ mes2013.pdf.]

Parker, R.L., and Adams, J.W., 1973, Niobium (columbium) and tantalum, in Brobst, D.A., and Pratt, W.P., eds., United States mineral resources: U.S. Geological Survey Professional Paper 820, p. 443-454. [Also available at http://pubs.er.usgs.gov/publication/pp820.]

Parker, R.L., and Fleischer, Michael, 1968, Geochemistry of niobium and tantalum: U.S. Geological Survey Professional Paper 612, 43 p. [Also available at http://pubs.er.usgs.gov/ publication/pp612.]

Partington, G.A., McNaughton, N.J., and Williams, I.S., 1995, A review of the geology, mineralization, and geochronology of the Greenbushes pegmatite, Western Australia: Economic Geology, v. 90, p. 616-635. [Also available at http://dx.doi.org/10.2113/gsecongeo.90.3.616.]

Paschoa, A.S., 1998, Potential environmental and regulatory implications of naturally occurring radioactive materials (NORM): Applied Radiation and Isotopes, v. 49, no. 3, p. 189-196. [Also available at http://dx.doi.org/10.1016/ S0969-8043(97)00239-X.]

Pires do Rio, M.A., Fernandes, H.M., Amaral, E.C.S., and Rochedo, E.R.R., 2003, Considerations about TENORMA study case on niobium facilities: Health Physics, v. 84, no. 2, p. 147-154.

Pollard, P.J., 1995, A special issue devoted to the geology of rare metal deposits - Geology of rare metal deposits - An introduction and overview: Economic Geology, v. 90, p. 489-494. [Also available at http://dx.doi.org/10.2113/ gsecongeo.90.3.489.] 
Quest Rare Minerals Ltd., 2012, Annual report 2011: Montreal, Quebec, Canada, Quest Rare Minerals Ltd., 68 p., accessed April 9, 2014, at http://www.questrareminerals.com/pdfs/ Quest RM Annual Report - Mar 26, 2012.pdf.

Raimbault, Louis, Cuney, Michel, Azencott, Claude, Duthou, J.L., and Joron, J.L., 1985, Geochemical evidence for a multistage magmatic genesis of Ta-Sn-Li mineralization in the granite at Beauvoir, French Massif Central: Economic Geology, v. 90, p. 548-576. [Also available at http://dx.doi.org/ 10.2113/gsecongeo.90.3.548.]

Ram Resources Ltd., 2012, Annual report 2012: West Perth, Western Australia, Australia, Ram Resources Ltd., 72 p., accessed April 9, 2014, at http:/web.archive.org/ web/20130425043951/http://ramresources.com.au/PDF/ annualreport12.pdf.

Reimann, C., and de Caritat, P., 1998, Chemical elements in the environment-Factsheets for the geochemist and environmental scientist: Berlin, Germany, Springer-Verlag, 397 p.

Richardson, D.G., and Birkett, T.C., 1996, Carbonatiteassociated deposits, in Eckstrand, O.R., Sinclair, W.D., and Thorpe, R.I., eds., Geology of Canadian mineral deposit types: Ottawa, Ontario, Canada, Geological Survey of Canada, Geology of Canada series, no. 8, part of Geology of North America series, v. P-1, p. 541-558.

Roskill Information Services Ltd., 2009, The economics of niobium (11th ed.): London, United Kingdom, Roskill Information Services Ltd., 222 p.

Roskill Information Services Ltd., 2012, Tantalum-Market outlook to 2016 (11 th ed.): London, United Kingdom, Roskill Information Services Ltd., 164 p.

Rudnick, R.L., and Gao, S., 2003, Composition of the continental crust, in Rudnick, R.L., ed., The crust, v. 3 of Holland, H.D., and Turekian, K.K., eds., Treatise on geochemistry, v. 3: Oxford, United Kingdom, ElsevierPergamon, p. 1-64. [Also available at http://dx.doi.org/ 10.1016/B0-08-043751-6/03016-4.]

Salvi, Stefano, and Williams-Jones, A.E., 2005, Alkaline granite-syenite deposits, in Linnen, R.L., Samson, I.M., Martin, R.F., eds., Rare-element geochemistry and mineral deposits: St. Johns, Newfoundland and Labrador, Canada, Geological Association of Canada, Short Course Notes, v. 17, p. $315-341$.

Schwela, Ulric, 2010, Mining Journal special publicationTantalum (A supplement to Mining Journal), with a section on The state of tantalum mining: London, United Kingdom, Aspermont, September, 11 p., accessed December 15, 2012, at http://www.mining-journal.com/_ data/assets/supplement file_attachment/0011/237287/Tantalum2010_scr.pdf.
Schwela, Ulric, 2011, T.I.C. statistics and transport project: Tantalum-Niobium International Study Center Bulletin, no. 145 , p. $2-8$.

Selway, J.B., Breaks, F.W., and Tindle, A.G., 2005, A review of rare-element (Li-Cs-Ta) pegmatite exploration techniques for the Superior Province, Canada, and large worldwide tantalum deposits: Exploration and Mining Geology, v. 14, nos. 1-4, p. 1-30. [Also available at http://dx.doi.org/10.2113/gsemg.14.1-4.1.]

Semenov, E., 1997, Minerals and ores of the Khibiny-Lovozero alkaline massif, Kola: Moscow, Russian Academy of Sciences, Fersman Mineralogical Museum, 70 p.

Siirama, Lauri, 2009, The Sokli Mine Project, Fennoskandian Mining and Exploration Congress, Rovaniemi, Finland, December 1-3, 2009, presentation, 17 p., accessed April 9, 2014, at http://fem.lappi.fi/c/document_library/ get_file?folderId=48927\&name=DLFE-2796.pdf.

Silva, A.C., Pereira, M.C., Oliveira, L.C.A., Cavalcante, L.C.D., Fabris, J.D., and Murad, E., 2012, An unusually stable magnetite from a niobium mine in Brazil: Clay Minerals, v. 47, no. 1, p. 69-79. [Also available at http://dx.doi.org/ 10.1180/claymin.2012.047.1.69.]

Smith, D.B., Cannon, W.F., Woodruff, L.G., Solano, Federico, Kilburn, J.E., and Fey, D.L., 2013, Geochemical and mineralogical data for soils of the conterminous United States: U.S. Geological Survey Data Series 801, 19 p. [Also available at http://pubs.usgs.gov/ds/801/.]

Smith, R.E., Perdrix, J.L., and Davis, J.M., 1987, Dispersion into pisolitic laterite from the Greenbushes mineralized Sn-Ta pegmatite system, Western Australia: Journal of Geochemical Exploration, v. 28, nos. 1-3, p. 251-265. [Also available at http://dx.doi.org/10.1016/03756742(87)90051-3.]

Sørensen, Henning, 2001, Brief introduction to the geology of the Ilímaussaq alkaline complex, South Greenland, and its exploration history, in Sørensen, Henning, ed., The Ilímaussaq Alkaline Complex, South Greenland-Status of mineralogical research with new results (Anniversary volume): Copenhagen, Denmark, Geological Survey of Denmark and Greenland, v. 190, p. 7-24.

Sørensen, Henning, ed., 1974, The alkaline rocks: New York, N.Y., Wiley Interscience, 622 p.

Steenfelt, Agnete, 1991, High technology metals in alkaline and carbonatitic rocks in Greenland-Recognition and exploration: Journal of Geochemical Exploration, v. 40, nos. 1-3, p. 263-279. [Also available at http://dx.doi.org/ 10.1016/0375-6742(91)90042-S.] 
Sweetapple, M.T., and Collins, P.L.F., 2002, Genetic framework for the classification and distribution of Archean rare metal pegmatites in the north Pilbara Craton, Western Australia: Economic Geology, v. 97, p. 873-895. [Also available at http://dx.doi.org/10.2113/gsecongeo.97.4.873.]

Tertiary Minerals plc, 2013, Ghurayyah: Macclesfield, United Kingdom, Tertiary Minerals plc Web page, accessed June 5, 2013, at http://www.tertiaryminerals.com/ ghurayyah.html.

Trueman, D.L., and Černý, Petr, 1982, Exploration for rareelement granitic pegmatites, in Cerný, P., ed., Granitic pegmatites in science and industry: Winnipeg, Manitoba, Canada, Mineralogical Association of Canada, Short Course Handbook, no. 8, p. 463-493.

U.S. Environmental Protection Agency, 2012, National recommended water quality criteria: U.S. Environmental Protection Agency Web page, accessed April 9, 2012, at http://www.epa.gov/waterscience/criteria/wqcriteria.html.

U.S. Environmental Protection Agency, 2013, Regional Screening Levels (RSL) summary table-November 2012: U.S. Environmental Protection Agency, accessed April 14, 2014, at http://www.epa.gov/reg3hwmd/risk/ human/rb-concentration_table/Generic_Tables/docs/ master_sl_table_run_NOV2013.pdf.

U.S. Geological Survey, 1996, Global 30 arc-second elevation (GTOPO30): Reston, Va., U.S. Geological Survey dataset (digital elevation model), accessed March 25, 2014, at https://lta.cr.usgs.gov/GTOPO30.

Upton, B.G.J., Emeleus, C.H., Heaman, L.M., Goodenough, K.M., and Finch, A.A., 2003, Magmatism of the mid-Proterozoic Gardar Province, South Greenland-Chronology, petrogenesis and geological setting: Lithos, v. 68, nos. 1-2, p. 43-65. [Also available at http://dx.doi.org/10.1016/ S0024-4937(03)00030-6.]

Ure, A.M., Bacon, J.R., Berrow, M.L., and Watt, J.J., 1979, The total trace element content of some Scottish soils by spark source mass spectrometry: Geoderma, v. 22, no. 1, p. 1-23. [Also available at http://dx.doi.org/10.1016/ 0016-7061(79)90036-3.]
Usikalu, M.R., Anoka, O.C., and Balogun, F.A., 2011, Radioactivity measurements of the Jos tin mine tailing in northern Nigeria: Archives of Physics Research, v. 2, no. 2, p. 80-86.

Viers, Jérôme, Dupré, Bernard, and Gaillardet, Jérôme, 2009, Chemical composition of suspended sediments in world rivers - New insights from a new database: Science of the Total Environment, v. 407, no. 2, p. 853-868. [Also available at http://dx.doi.org/10.1016/j.scitotenv.2008.09.053.]

Winter, Mark, 2014, Niobium-The essentials: WebElements, accessed April 4, 2014, at http://www.webelements.com/.

Wood, S.A., 2005, The aqueous geochemistry of zirconium, hafnium, niobium, and tantalum, in Linnen, R.L., Samson, I.M., and Martin, R.F., eds., Rare-element geochemistry and mineral deposits: St. Johns, Newfoundland and Labrador, Canada, Geological Association of Canada, Short Course Notes, v. 17, p. 217-268.

Woolley, A.R., and Bailey, D.K., 2012, The crucial role of lithospheric structure in the generation and release of carbonatites - Geological evidence: Mineralogical Magazine, v. 76, no. 2, p. 259-270. [Also available at http://dx.doi.org/10.1180/minmag.2012.076.2.02.]

Woolley, A.R., and Kjarsgaard, B.A., 2008, Carbonatite occurrences of the world-Map and database: Geological Survey of Canada Open File 5796, 28 p., 1 CD-ROM plus 1 map, scale approx. 1:19,000,000. [Also available at http://dx.doi.org/10.4095/225115.]

Yin, Lin, Pollard, P.J., Shouxi, Hu, and Taylor, R.G., 1995, Geologic and geochemical characteristics of the Yichun Ta-Nb-Li deposit, Jiangxi Province, south China: Economic Geology, v. 90, p. 577-585. [Also available at http://dx.doi.org/10.2113/gsecongeo.90.3.577.] 
For more information concerning this report, please contact:

Mineral Resources Program Coordinator

U.S. Geological Survey

913 National Center

Reston, VA 20192

Telephone: 703-648-6100

Fax: 703-648-6057

Email:minerals@usgs.gov

Home page: https://minerals.usgs.gov

Prepared by the USGS Science Publishing Network Reston Publishing Service Center

Edited by J.C. Ishee and Stokely J. Klasovsky Illustrations Caryl J. Wipperfurth

Layout by Caryl J. Wipperfurth and Cathy Knutson Posting by Angela E. Hall 
